UNIVERSIDADE DE SÃO PAULO

ESCOLA DE ENFERMAGEM

ADRIANA AVANZI MARQUES PINTO

AS POTENCIALIDADES DO AGENTE COMUNITÁRIO DE SAÚDE NA EFETIVAÇÃO DA PROMOÇÃO DA SAÚDE: UMA ANÁLISE DAS SUAS AÇÕES NO MUNICÍPIO DE MARÍLIA - SP

SÃO PAULO

2010 


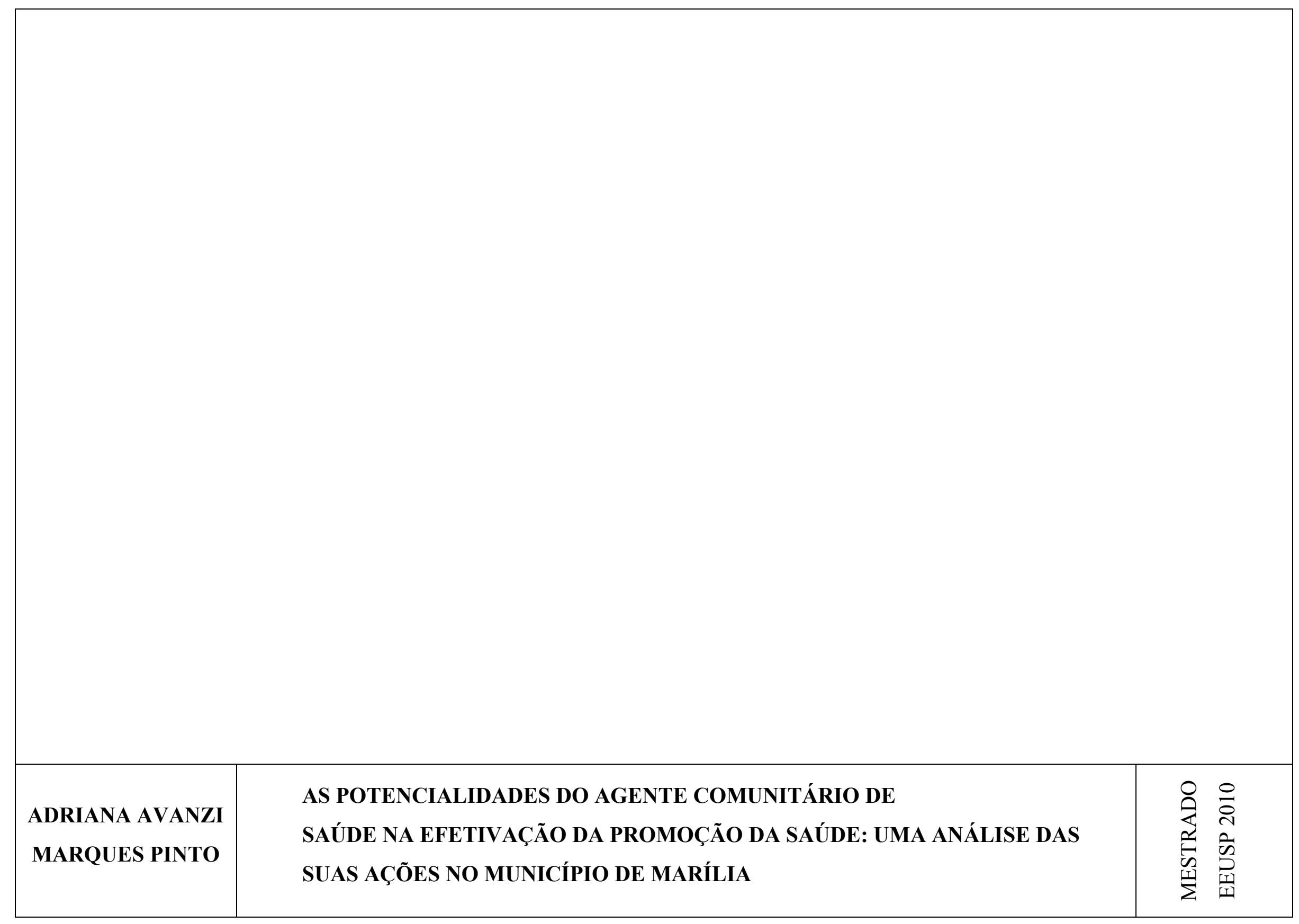




\section{AS POTENCILIDADES DO AGENTE COMUNITÁRIO DE SAÚDE NA EFETIVAÇÃO DA PROMOÇÃO DA SAÚDE: UMA ANÁLISE DAS SUAS AÇÕES NO MUNICÍPIO DE MARÍLIA}

Dissertação de Mestrado apresentada ao Departamento de Saúde Coletiva da Escola de Enfermagem da Universidade de São Paulo para obtenção de grau de Mestre

Orientadora:

Prof $^{\mathrm{a}}$ Dr $^{\mathrm{a}}$ Lislaine Aparecida Fracolli 
AUTORIZO A REPRODUÇÃO E DIVULGAÇÃO TOTAL OU PARCIAL DESTE TRABALHO, POR QUALQUER MEIO CONVENCIONAL OU ELETRÔNICO, PARA FINS DE ESTUDO E PESQUISA, DESDE QUE CITADA A FONTE.

Assinatura: Data

Escola de Enfermagem da Universidade de São Paulo

Pinto, Adriana Avanzi Marques

As Potencialidades do agente comunitário de saúde na efetivação da promoção da saúde: uma analise das suas ações no município de Marília - SP./ Adriana Avanzi Marques Pinto. - São Paulo, 2010.

$122 \mathrm{p}$.

Dissertação (Mestrado) - Escola de Enfermagem da Universidade de São Paulo.

Orientadora: $\operatorname{Prof}^{\mathrm{a}} \mathrm{Dr}^{\mathrm{a}}$ Lislaine Aparecida Fracolli

1. Agente Comunitário de Saúde 2. Promoção da Saúde 3. Programa Saúde da Família 
Nome: Adriana Avanzi Marques Pinto

Título: As Potencialidades do agente comunitário de saúde na efetivação da promoção da saúde: uma analise das suas ações no município de Marília - SP

Dissertação de Mestrado apresentada ao Departamento de Saúde Coletiva da Escola de Enfermagem da Universidade de São Paulo para obtenção do grau de Mestre.

Aprovado em:

Banca examinadora:

Prof. Dr. Instituição:

Julgamento: Assinatura:

Prof. Dr. Instituição:

Julgamento: Assinatura:

Prof. Dr. Instituição:

Julgamento: Assinatura:

Prof. Dr. Instituição:

Julgamento: Assinatura: 


\section{DEDICATÓRIA}

Em primeiro lugar a Deus que me concedeu essa oportunidade de aprimorar meus conhecimentos e entender um pouco mais sobre a vida.

À meus Pais que me deram a base para que eu chegasse até aqui.

Ao Fabiano, esposo, companheiro de todos os momentos, pela compreensão e carinho ao longo do período de elaboração deste trabalho.

As minhas "meninas" Belinha e Nina, que se mantiveram sempre comigo nos momentos de estudo em casa.

A minha irmã Fernanda que cedeu moradia em seu apartamento nos momentos que estive em São Paulo.

A todos os meus amigos, que me acompanharam nessa trajetória, em especial a Enfermeira Fernanda por me mostrar o caminho para chegar até aqui. 


\section{AGRADECIMENTOS}

À orientadora e amiga, Prof. ${ }^{\text {a }}$ Dr. $^{\text {a }}$ Lislaine Aparecida Fracolli, pela competência, disponibilidade e paciência que conduziu esse estudo, do inicio até sua conclusão.

As Professoras Dra. ${ }^{a}$, EIma Zabolli e Dr. ${ }^{a}$ Ana Maria Chiesa, pelas valiosas contribuições no Exame de Qualificação.

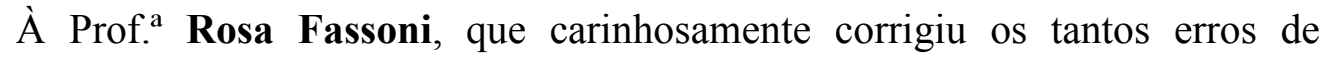
português presente nesse trabalho.

Ao Ira que me auxiliou na parte de formatação gráfica

Aos meus queridos amigos, que acompanharam e muito me ajudaram durante o mestrado: Tatiane, Diego, Ângela, Adriana, Gabi, Heitor e Sheila.

Ao professor, de estatística Ricardo, que me auxiliou com a compilação e análise dos dados.

A todos funcionários da EESP, em especial a Silvana da Pós-graduação, a Terezinha, as funcionárias do refeitório e da gráfica, o meu muito obrigada!

A todos os colegas de trabalho das equipes da ESF de Marília - SP, em especial aos Agentes Comunitários de Saúde, que gentilmente aceitaram participaram desta pesquisa.

À Secretaria de Saúde de Marília pelo apoio prestado e pela liberação para realização desta pesquisa.

Aos familiares, amigos e todos aqueles que enviaram energia positiva, além da paciência em entender e aceitar tantos momentos ausentes. 
Devia ter amado mais Ter chorado mais Ter visto o sol nascer Devia ter arriscado mais e até errado mais Ter feito o que eu queria fazer Queria ter aceitado as pessoas como elas são Cada um sabe a alegria e a dor que traz no coração O acaso vai me proteger Enquanto eu andar distraído? O acaso vai me proteger Enquanto eu andar...

Devia ter complicado menos, trabalhado menos Ter visto o sol se pôr Devia ter me importado menos com problemas pequenos Ter morrido de amor Queria ter aceitado a vida como ela é A cada um cabe alegrias e a tristeza que vier O acaso vai me proteger Enquanto eu andar distraído? O acaso vai me proteger Enquanto eu andar... Devia ter complicado menos, trabalhado menos Ter visto o sol se pôr. Devia ter complicado menos, trabalhado menos Ter visto o sol se pôr.

(Musica: Epitáfio, Titãs, compositor Sergio Britto) 
Pinto AAM. As Potencialidades do agente comunitário de saúde na efetivação da promoção da saúde: uma analise das suas ações no município de Marília - SP. [dissertação]. São Paulo: Escola de Enfermagem, Universidade de São Paulo: 2010.

\section{RESUMO}

Este estudo tem como objetivo descrever e analisar, as ações realizadas pelos agentes comunitários de saúde (ACS) do município de Marília (SP), em relação a sua potencialidade na efetivação da Promoção da Saúde, na perspectiva do fortalecimento da comunidade. Tratou-se de uma pesquisa quantitativa, em que os sujeitos foram os 298 Agentes Comunitários de Saúde (ACS) que atuam na Atenção Básica do município de Marilia-SP. O instrumento de coleta de dados foi um questionário estruturado que abordava características sócio-demograficas dos sujeitos, além de ser um inventario das ações relativas as cinco competências propostas pelo Ministério da Saúde para o Agente Comunitário.Os dados foram organizados com o auxilio do software SPSS (versão 17) e analisados com base na frequencia simples de ocorrência das ações. O quadro teórico que suporta as discussões dos resultados baseou-se no modelo de organização comunitária e construção de capacidade para avaliar a Promoção da Saúde, proposto por Nutbeam (2004). Os resultados apontam que os ACS apresentam uma prática voltada para ações de prevenção à doenças. Na competência Promoção da Saúde, se observou um equilíbrio entre as freqüências diariamente e raramente, o que mostra não haver uma padronização das ações relacionadas à promoção da saúde, as quais de certa forma, pouco contribuem para o fortalecimento das comunidades. Como conclusão, sugerese que as ações do ACS tomem por base a realidade de cada território e a partir daí se identifiquem as demandas, tanto da equipe quanto da comunidade, a fim de se partilhar saberes científicos e populares na busca do fortalecimento da comunidade para o enfrentamento do processo saúde-doença.

Palavras-chave: Agente comunitário de saúde, Promoção da Saúde, Programa saúde da Família. 
Pinto AAM. Título. The potentialities of community health work in the realization of health promotion: a review of their actions in the Marília's city [dissertação]. São Paulo: Escola de Enfermagem, Universidade de São Paulo: 2010.

\begin{abstract}
This study aims to describe and analyze the actions carried out by community health work (CHW) in Marília (SP), about his potential in the realization of health promotion, in a view of to strengthening the community. This was a quantitative research, realized with 298 subjects, who work in primary health care in the Marilia's city. The instrument of data collection was a structured questionnaire which addressed socio-demographic characteristics of subjects, in addition includes an inventory of the five competences proposed by the Ministry of Health to the community health. The datas were organized with the SPSS software (version 17) and analyzed by simple frequency of occurrence the actions. The theoretical framework that supports the discussion of the results was based on the model of community organization and capacity building to assess the Promotion Health, proposed by Nutbeam (2004). The results show that the CHW have a practice focused on actions to prevent the disease. In the Health Promotion competence has been a balance between daily and rarely frequencies, that shows there is not standardization of the health promotion actions, wich a little bit contribute to the communities' empowerment. In conclusion, the suggestion is the actions of the CHW take based on the reality of each area and identify the demands of both, the team and the community, in order to share scientific and popular knowledge in the search for community empowerment and confronting to the health-disease process.
\end{abstract}

Key Words: Community health work, Health Promotion, Family health program. 


\section{LISTA DE ILUSTRAÇÕES}

Figura 1 Dimensões da organização comunitária e da capacidade de construção

Figura 2 Mapa da distribuição das unidades da rede de atenção básica 54 do município de Marília e seu projeto de expansão das USF. Marília - 2009. 


\section{LISTA DE QUADROS}

Quadro 1 Quadro I - Perfil do Município de Marília em relação ao Estado de São Paulo conforme o ano.

Quadro 2 Caracterização do ACS conforme idade, número de filhos, renda familiar, número de pessoas que vivem com a renda referida, tempo de residência no bairro e tempo de trabalho na ESF e UBS no município de Marília - 2009. 


\section{LISTA DE TABELAS}

Tabela 1 Distribuição dos Agentes Comunitários de Saúde segundo os 58 dados sociodemográficos, Marília - 2009.

Tabela 2 Relação das principais profissões citadas pelos respondentes $\quad 60$ antes de ingressar na profissão de ACS, Marília - 2009.

Tabela 3 Detalhamento da inserção no trabalho dos ACS do município 61 de Marília - 2009.

Tabela 4 Distribuição da ação "Identifica a relação entre problemas 91 de saúde e condições de vida" (C1) realizada pelos ACS da UBS e ESF isoladamente. Marília - 2009

Tabela 5 Distribuição da ação "Identifica exemplos positivos que promovem a saúde na comunidade" (C2) realizada pelos ACS da UBS e ESF isoladamente. Marília - 2009

Tabela 6 Distribuição da ação "Estimula indivíduos e a comunidade a refletirem sobre suas condições de saúde e doença" (C7) realizada pelos ACS da UBS e ESF isoladamente. Marília 2009

Tabela 7 Distribuição da ação "Orienta a população quanto a medidas de proteção à saúde" (C9) realizada pelos ACS da UBS e ESF isoladamente. Marília - 2009

Tabela 8 Distribuição da ação "Propõe ações que utilizem as diversas secretarias existentes no município de Marília" (C11) realizada pelos ACS da UBS e ESF isoladamente. Marília 2009

Tabela 9 Distribuição da ação "Estabelece parcerias com creches, asilos, escolas, comerciantes, grupos sociais e outros" (C13) realizada pelos ACS da UBS e ESF isoladamente. Marília - 2009

Tabela 10 Distribuição da ação "Executa ações que atuam em parceria com outras secretarias existentes no município de Marília" (C12) realizada pelo ACS da UBS e ESF. Marília2009

Tabela 11 Distribuição da ação "Participa de reuniões de conselho local de saúde ou de outros conselhos locais" (C16) realizada pelos ACS da UBS e ESF. Marília - 2009 


\section{LISTA DE GRÁFICOS}

Gráfico 1 Distribuição da Frequência das ações realizadas pelos ACS 66 relacionadas à Competência A -“Integração da equipe com a população local”. Marília - 2009

Gráfico 2 Frequência das ações realizadas raramente e diariamente pelos ACS na competência "Integração com a equipe com a população local". Marília - 2009

Gráfico 3 Distribuição da Frequência das ações realizadas pelos ACS, relacionadas à competência B - Planejamento e Avaliação. Marília - 2009

Gráfico 4 Freqüência das ações realizadas raramente e diariamente pelos ACS na competência Planejamento e avaliação. Marília - 2009

Gráfico 5 Distribuição da Frequência das ações realizadas pelos ACS relacionadas à competência C - "Promoção da Saúde". Marília - 2009

Gráfico 6 Frequência das ações realizadas raramente e diariamente pelos ACS na competência "Promoção da Saúde". Marília 2009

Gráfico 7 Distribuição da Frequência das ações realizadas pelos ACS relacionadas à competência D - Prevenção e monitoramento de risco ambiental e sanitário. Marília-2009

Gráfico 8 Frequência das ações realizadas raramente e diariamente pelos ACS na competência D - Prevenção e monitoramento de risco ambiental e sanitário. Marília - 2009

Gráfico 9 Distribuição da Frequência das ações realizadas pelos ACS relacionadas à competência $\mathrm{E}$ - Prevenção e monitoramento a grupos específicos e morbidades. Marília - 2009

Gráfico 10 Frequência das ações realizadas raramente e diariamente pelos ACS na competência E - Prevenção e monitoramento a grupos específicos e morbidades. Marília - 2009 


\section{LISTA DE SIGLAS}

ACS - Agente comunitário de Saúde

CLS - Conselhos locais de Saúde

CLT - Consolidação das Leis Trabalhistas

COMUS - Conselho Municipal de Saúde

DEVALE - Projeto de Expansão dos Serviços Básicos de Saúde e Saneamento em Área Rural - Vale do Ribeira

EMEI - Escola Municipal de Ensino Infantil

EMEF - Escola Municipal de Ensino Fundamental

EMEFEIs - Escolas Municipais de Ensino Fundamental e de Educação Infantil

ESF - Estratégia Saúde da Família

FAMEMA - Faculdade de Medicina de Marília

FSESP - Fundação Nacional de Saúde Pública

IBGE - Instituto Brasileiro de Geografia Estatística

IPRS - Índice Paulista de Responsabilidade Social

MS - Ministério da Saúde

OMS - Organização Mundial de Saúde

PA - Pronto-atendimentos

PACS - Programa de Agentes Comunitários de Saúde

PIASS - Programa de Interiorização de Ações de Saúde e Saneamento

PNACS- Programa Nacional de Agentes Comunitários

PROIID - Programa de internação e interação domiciliar

PSF - Programa Saúde da Família

SEADE - Fundação Sistema Estadual de Análise de Dados

SESP - Secretaria de Estado de Segurança Pública 
SIAB - Sistema de Informação da Atenção Básica

SMS - Secretaria Municipal de Saúde

SMHS - Secretaria Municipal de Higiene e Saúde

SUS - Sistema Único de Saúde

UBS - Unidade Básica de Saúde

UCAF - Unidade Central de Assistência farmacêutica

CAPS - Centro de Atenção Psicossocial

NVS - Núcleo de vigilância a saúde

NEPEM - Núcleo de Educação Permanente

CTE - Centro de treinamento em vigilância a saúde

CEO - Centro de especialidades odontológicas

CEPROM - Centro profissionalizante de Marília

CRAS - Centro de Referencia de Assistência Social

CREAS - Centro de referência especializado de assistência social

SPSS - Acrónimo de Statistical Package for the Social Sciences

UNICEF - Fundo das Nações Unidas para a Infância

USF - Unidade de Saúde da Família

USP - Universidade de São Paulo 


\section{SUMÁRIO}

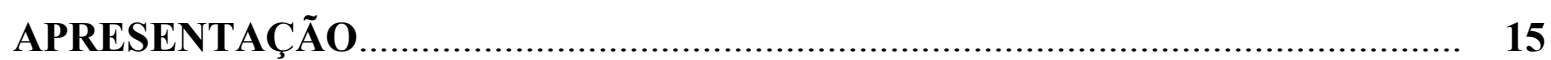

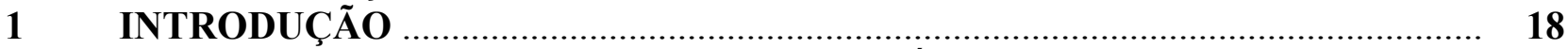

1.1 CARACTERIZAÇÃO DO AGENTE COMUNITÁRIO: UM PROFISSIONAL NOVO NA EQUIPE DE SAÚDE QUE VEM CONTRIBUIR NO PROCESSO DE CUIDAR.

1.2 O RETRATO DO TRABALHO DO ACS E SUA RELAÇÃO COM A PROMOÇÃO DA SAÚDE

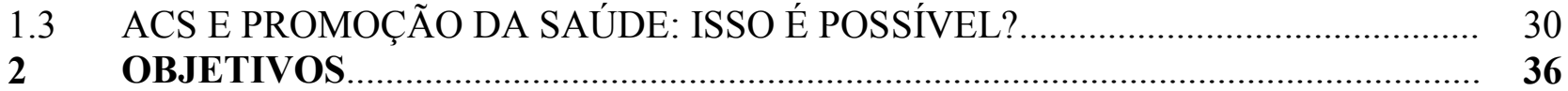

3 BASES TEÓRICAS DA INVESTIGAÇÃO...

3.1 ALGUNS ASPECTOS CONCEITUAIS DA PROMOÇÃO DA SAÚDE.

3.2 FORMULAÇÕES TEÓRICO-CONCEITUAIS PARA A PESQUISA EM PROMOÇÃO DA SAÚDE.

4 METODOLOGIA.

4.1 ASPECTOS METODOLÓGICOS DA PESQUISA.

4.2 CENÁRIO DE ESTUDO: A CONTEXTUALIZAÇÃO DA HISTÓRIA DE SAÚDE DO MUNICÍPIO DE MARÍLIA NA SUA TRAJETÓRIA DE IMPLEMENTAÇÃO

DE UM NOVO MODELO DE ATENÇÃO À SAÚDE.......

4.3 CENÁRIO DE ESTUDO: AS ESPECIFICIDADES DO SETOR SAÚDE........................ 50

4.4 SUJEITOS DA PESQUISA..................................................................................... 54

4.5 COLETA DE DADOS: INSTRUMENTO E PROCEDIMENTOS UTILIZADOS

4.6 CONSIDERAÇÕES ÉTICAS SOBRE A PESQUISA ………………………….......... 56

5 RESULTADOS E DISCUSSÃO

5.1 CARACTERIZAÇÃO DEMOGRÁFICA DOS ACS DO MUNICÍPIO DE MARÍLIA............................................................................................................... 58

5.2 CARACTERIZAÇÃO DAS COMPETÊNCIAS DE ATUAÇÃO DO ACS, CONFORME PROPOSTO PELO MINISTÉRIO DA SAÚDE ATRAVÉS DE FREQUÊNCIAS SIMPLES.

5.2.1 Descrição e análise da competência $\mathrm{A}$ - "integração da equipe com a população local".....

5.2.2 Descrição e análise da competência B - "planejamento e avaliação"............................... 70

5.2.3 Descrição e análise da competência C - "promoção da saúde"........................................ 74

5.2.4 Descrição e análise da competência D - "prevenção e monitoramento de risco 81 ambiental e sanitário".

5.2.5 Descrição e análise da competência E - "prevenção e monitoramento a grupos específicos e morbidades"...................................................................................... 84

5.2.6 Análise, com base em cruzamentos de ações complementares....................................... 90

CONSIDERAÇÕES FINAIS.......................................................................... 100

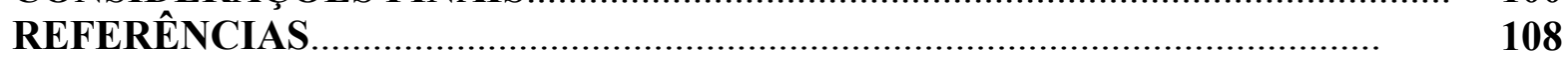

ANEXOS 


\section{APRESENTAÇÃO}

Ao ingressar na faculdade de enfermagem da FAMEMA (Faculdade de Medicina de Marília) pude conhecer um pouco mais sobre o que era a área da saúde. Antes da faculdade eu tinha uma noção do que seria trabalhar com pessoas, mas somente nas atividades desenvolvidas durante o curso foi que pude entender como é rico e profundo o relacionamento entre os profissionais da saúde e as pessoas que procuram por atendimento devido a alguma alteração, seja ela física, psíquica ou social. No início, entendia saúde com ausência de doenças. Afinal, se não estou doente, estou saudável. Porém, ao longo dos quatro anos de graduação, esse conceito foi mudando e fui percebendo que ter saúde significa bem mais que não estar doente, entendi que o ser humano deve ser visto de forma holística, que é preciso entender suas necessidades, seu contexto familiar, seu modo de vida, pois tudo isso pode interferir no processo saúde-doença.

Por um ano trabalhei em um hospital na área de clínica cirúrgica e percebi que aquele não era o caminho que gostaria de seguir na área da enfermagem. Sentiame como se estivesse em um processo inacabado, pois não sabia de onde provinha nem para onde iria aquele "paciente" após a cirurgia. Percebi, então, que meu objetivo era trabalhar na atenção básica, trabalhar na Estratégia Saúde da Família (ESF) e migrei para essa área. Neste ambiente, pude entender melhor a dinâmica das famílias, o modo de vida das pessoas que procuravam o serviço de saúde com problemas cuja solução demandava outros setores, pois não eram específicos da saúde. Já se passaram cinco desde que ingressei na ESF. No início fiquei dois anos em uma unidade de saúde da família (USF) na zona rural, depois mais um ano como enfermeira substituta e hoje estou em uma USF localizada na zona urbana.

Neste período aprendi muito e percebi que precisava conhecer mais profundamente o papel profissional daquele que deve ligar o serviço de saúde e as comunidades, o Agente Comunitário de Saúde (ACS). Por coincidência, nessa época, uma amiga muito querida e egressa do programa de mestrado dessa instituição, apresentou-me ao grupo de pesquisa Modelos Técnico-Assistenciais de Promoção da Saúde, da Escola de Enfermagem da USP. Ali foi possível entender um pouco mais de Saúde Coletiva e percebi que ainda devia aprender muito sobre os sujeitos, 
comunidades, suas relações sociais, os determinantes sociais e o que tudo isso pode influenciar no processo saúde-doença.

Assim, durante pouco mais de dois anos naquele grupo de pesquisa, procurei conhecer a fundo as ações realizadas pelos ACS no município de Marília, verificando qual a potencialidade dessas ações para a efetivação da Promoção da Saúde. Esse era um assunto muito debatido na faculdade, e só após esse tempo pude me aproximar mais desse "campo de saberes e práticas", que tanto tem a acrescentar no nosso trabalho na área da saúde. A partir daí me convenci que o processo saúde-doença é muito maior do que pensamos e que os determinantes sociais estão, a todo o momento, nos mostrando os caminhos para desempenharmos uma assistência de qualidade e baseada no individuo, levando em conta sua inserção na sociedade e seu papel como cidadão.

Esse conhecimento não foi repentino: durou os quatro anos de faculdade e os cinco de experiência profissional. Penso, porém, que ainda há muito o que aprender. Penso que não basta apenas atribuir funções às pessoas, sem que elas saibam o porquê de estarem fazendo algo, isso não garante que o produto final seja satisfatório. É preciso que, continuamente, seja feita a reflexão da prática de nossas ações. Por isso questiono se basta atribuir ao ACS as competências a serem desempenhadas no dia a dia de seu trabalho. De que forma podemos implementar ações voltadas à Promoção da Saúde? E os demais membros da equipe de saúde, como podem favorecer para que isso aconteça?

A partir desses questionamentos cheguei ao que essa pesquisa buscou demonstrar em relação às ações desempenhadas pelos ACS do município de Marília, na efetivação da Promoção da Saúde. Todo esse processo foi orientado pela $\mathrm{Dr}^{\mathrm{a}}$ Lislaine Aparecida Fracolli, que muito me auxiliou durante essa trajetória e contribuiu para que eu continuasse na área da pesquisa em Saúde Coletiva e, num futuro mais próximo, ingresse na carreira acadêmica. 
INTRODUÇÃO 


\section{INTRODUÇÃO}

Na perspectiva da Promoção da Saúde, alguns países procuraram reestruturar o sistema de assistência à saúde de que dispunham. Estas formas de superação foram propostas através de instrumentos e diretrizes que direcionavam para um modelo que fortalecesse a participação social, a equidade e a integralidade. Nessa perspectiva, o Ministério da Saúde (MS) propôs a Estratégia de Saúde da Família (ESF) ${ }^{1}$.

O ESF surge em 1994 com objetivo de reorganizar a prática assistencial, substituindo o modelo de assistência à saúde centrado na prática médica, por um modelo centrado na família, a partir de sua inserção social, possibilitando entender o processo saúde-doença de forma ampliada, gerando intervenções que busquem mais do que ações curativas ${ }^{1}$, e que favoreçam o empowerment comunitário, a equidade social e a integralidade ${ }^{2}$.

Em 2006 o Programa Saúde da Família passa a receber a denominação de Estratégia Saúde da Família, pois se deixa a idéia de algo que está pronto e consolidado para se pensar em uma estratégia de atender as necessidades da comunidade assistida nas suas diferentes peculiaridades ${ }^{3}$.

A ESF foge da concepção usual dos programas tradicionais concebidos pelo Ministério da Saúde, pois não se trata de uma intervenção pontual no tempo e no espaço e tampouco de forma vertical ou paralela às atividades rotineiras dos serviços de saúde. Ao contrário, objetiva a integração e a organização das atividades em um território definido, com um propósito de enfrentar e resolver os problemas identificados, com vistas a mudanças radicais no sistema, de forma articulada e perene $^{4}$. Para tanto, a ESF se constitui em uma estratégia de substituição e reestruturação do modelo a partir da Atenção Básica.

A composição da equipe mínima de saúde na ESF, conforme descrito no guia prático, é inter e multidisciplinar: tem-se um médico, um enfermeiro, cinco a seis ACS e um auxiliar de enfermagem. Esta equipe nuclear prioriza ações de prevenção, promoção e recuperação da saúde, de forma integral, proporcionando a criação de vínculos de co-responsabilidade, facilitando a identificação e a resolução dos problemas encontrados ${ }^{5}$. Sob a responsabilidade de uma equipe de saúde ficam até 
1000 famílias ou 4500 pessoas, sendo que no mínimo cada ACS fica com 400 pessoas e no máximo 750 pessoas $^{6}$.

$\mathrm{O}$ processo de trabalho na ESF busca atender ao modelo de vigilância à saúde, no qual a unidade de saúde funciona como porta de entrada no sistema, e o trabalho multiprofissional da equipe de saúde fica responsável pela área adscrita definida ${ }^{1}$. Com base nos princípios do Sistema Único de Saúde (SUS), as ações das unidades de saúde da família são pautadas na universalidade, equidade, integralidade e participação social, o que favorece entender a saúde e a doença como um processo e, assim, ao pensar em intervenções, surge a idéia de Promoção da Saúde, e não apenas a prevenção de doenças e agravos.

O ACS surge nesse cenário como um novo profissional que vem contribuir para esse novo processo de cuidar.

\subsection{CARACTERIZAÇÃO DO AGENTE COMUNITÁRIO: UM PROFISSIONAL NOVO NA EQUIPE DE SAÚDE QUE VEM CONTRIBUIR NO PROCESSO DE CUIDAR}

O ACS não é uma invenção da ESF, esse profissional originou-se de experiências chinesas e cubanas divulgadas na Conferência Internacional de Cuidados Primários em Saúde, promovida pela Organização Mundial de Saúde (OMS) e pelo Fundo das Nações Unidas para a Infância (UNICEF), em 1978, na cidade de Alma-Ata, Cazaquistão. Esta conferência teve grande repercussão por favorecer a implantação, em inúmeros países, de programas de Atenção Primária para populações específicas, com a participação de $\mathrm{ACS}^{7,8}$.

No relatório final da Conferência de Alma-Ata, os participantes afirmaram que o cuidado primário de saúde seria o principal meio para que todas as populações do mundo pudessem alcançar um padrão aceitável de saúde em um futuro próximo. A referência à utilização do ACS aparece quando se elaboram as ações e competências que compõem os cuidados primários de saúde como primeiro nível de organização do sistema de saúde ${ }^{8,9}$. 
As primeiras intervenções centradas no domicílio, no país, foram realizadas por visitadoras sanitárias com vistas às ações de prevenção de doenças, promoção da saúde e monitoramento e acompanhamento de grupos de risco. O início dessas ações se deu no Serviço Especial de Saúde Pública (SESP), em 1942 ${ }^{10,11}$, através de atividades influenciadas pela medicina preventiva com base nos modelos norteamericanos para as áreas de interesse estratégico dos países aliados na guerra contra a Alemanha. Recebiam assistências os trabalhadores da Amazônia, Espírito Santo, Minas Gerais e Goiás e das áreas de combate à malária. As ações desenvolvidas eram as relacionadas à saúde pública, como controle de doenças transmissíveis, educação sanitária, saneamento do meio-ambiente; atividades de assistência médica à saúde da mulher, adulto e criança; e atividades laboratoriais como exame de urina, sangue, escarro entre outros ${ }^{10}$.

Em 1960 têm-se a continuidade das ações do SESP através da Fundação Serviço Especial de Saúde Pública (FSESP), que inicialmente centrou suas ações no saneamento e combate de endemias locais. Essa instituição contribuiu de forma significativa para as diretrizes que hoje orientam as práticas de trabalho do Programa de Agentes Comunitários de Saúde (PACS) e da ESF ${ }^{10,11}$.

No fim da década de 1970, tem-se o Programa de Interiorização de Ações de Saúde e Saneamento (PIASS), que buscava um melhor acesso das populações marginalizadas aos serviços de saúde, o que se assemelha, hoje, ao programa de agentes comunitários de saúde. Suas ações podiam estar ligadas desde a aspectos do meio ambiente como até a situações sanitárias que demandassem assistência médica individual. Neste contexto, mais especificamente no Estado de São Paulo, destaca-se o Projeto de Expansão dos Serviços Básicos de Saúde e Saneamento em Área Rural - Vale do Ribeira (DEVALE), que faz parte da segunda etapa de implantação do PIASS. Seu foco de ação estava no recrutamento de agentes de saúde da própria comunidade rural para o desempenho de ações comunitárias e individuais ${ }^{8}$, com o objetivo de ampliação do acesso a informações de saúde e de formação de auxiliares de saúde ${ }^{10}$.

O processo de escolha desse profissional, a princípio, foi definido através de critérios como: não fazer distinção entre as pessoas, saber ler e escrever, ter "jeito para coisa", não ter medo de sangue, ser responsável, ser maior de idade, entre outras. Em algumas localidades, outros critérios também eram exigidos, como comprometimento 
com a comunidade, ter boa vontade, ter tempo, ser educado, ser calmo, não beber, entre outras ${ }^{12}$.

Após a seleção dessas qualidades, eram sugeridos nomes de pessoas que atendiam aos requisitos. Em seguida acontecia a eleição através de voto secreto. Embora fosse claro que homens e mulheres pudessem desempenhar a função, após a votação verificou-se a maioria absoluta de mulheres. Em seguida, ocorreram treinamentos para capacitação deste profissional ${ }^{12}$.

Em 1991, o Ministério da Saúde propôs o Programa Nacional de Agentes Comunitários (PNACS) que, em 1992, muda para Programa de Agentes Comunitários de Saúde (PACS). O Ceará foi pioneiro nas experiências com ACS, contribuindo de forma efetiva para o programa de forma nacional. Houve contratação de diversos trabalhadores, tendo como critério de contratação a renda, com intenção de empregar mulheres que se encontravam em regiões mais pobres, a fim de melhorar as condições de vida deste grupo ${ }^{10}$.

O programa se estendeu para 45 municípios do interior do Ceará, tendo como objetivo geral do programa a melhoria da capacidade da comunidade em cuidar da sua própria saúde, e como objetivo específico a redução da mortalidade infantil e materna ligada ao parto, estímulo ao aleitamento materno exclusivo até o $4^{\circ}$ mês de vida e a redução da mortalidade por desidratação ligada à diarréia. Os agentes deveriam trabalhar com os membros da comunidade que já desempenhavam atividades ligadas à saúde como parteiras e curandeiras, a fim de estimular parcerias e a proteção à saúde ${ }^{10}$.

No PACS, o objetivo geral era o de melhorar a capacidade da população em cuidar da sua saúde através da atuação dos Agentes de Saúde, além de proporcionar a interação dos serviços de saúde com a população local; como objetivos específicos tinha-se a capacitação do ACS para executar ações de primeiro nível de atenção à saúde, garantir a ligação do trabalho do ACS à unidade de saúde, fortalecer o vínculo do serviço ${ }^{10}$.

Com base na experiência do programa de agentes comunitários no Ceará, foi definida a forma de seleção dos agentes. Os critérios são: idade mínima de 18 anos, ter $1^{\circ}$ grau completo (ensino fundamental completo), residir há mais de dois anos na área de abrangência da unidade de saúde, disponibilidade de 8 horas de trabalho por dia. Após o término do processo de seleção, os aprovados passavam por um 
treinamento com o objetivo de ampliar a visão da situação de saúde da comunidade a ser assistida. Em 1994, o PACS passou por uma avaliação realizada pelo Estado, em conjunto com a academia, a fim de entender os pontos positivos e negativos do programa; afinal, o objetivo era a expansão para o todo país ${ }^{10}$.

Como pontos positivos, destacam-se o aumento da cobertura vacinal, a terapia de reidratação oral e o início precoce do pré-natal. Já em relação aos pontos que mereciam melhor atenção, verificou-se a necessidade de aprimoramento na forma de supervisão e formação desses agentes, aprimoramento da integração deles com os demais membros da equipe de saúde e serviços de saúde, e melhorias na interação do Programa com sistema de saúde dos municípios ${ }^{10}$.

Após esse breve histórico da trajetória do ACS - a princípio auxiliares de saúde; após, agentes de saúde e, por fim Agente comunitário de saúde — ressalta-se duas considerações em relação ao ACS: seu trabalho vai além do atendimento às necessidades dos grupos sociais, é mais que um simples trabalho, transcende a saúde; aborda sua relação com a instituição e a comunidade, interação esta que contribui para a formação de sua identidade, pois, no início, sua abordagem era mais centrada no polo comunidade, prevalecendo o saber do senso comum desse personagem ${ }^{8}$.

Considera-se que o trabalho do ACS apresenta três dimensões:

- dimensão técnica: atende indivíduos e família através de ações de monitoramento de grupos específicos, doenças prevalentes e de risco, através de visitas domiciliares e informação em saúde com base no saber epidemiológico e clínico;

- dimensão política: o ACS é quem reorienta o modelo de atenção à saúde na discussão dos problemas e organização da comunidade, auxiliando no fortalecimento da cidadania, através das visitas domiciliares e educação em saúde, com base nos saberes da saúde coletiva;

- dimensão da assistência social: há uma tentativa de se resolver questões, entre elas a de acesso aos serviços ${ }^{13}$.

$\mathrm{Na}$ tentativa de conciliar estas três dimensões, o trabalho do ACS se apresenta de forma conflituosa, pois, na prática, suas ações tendem para apenas um desses pólos, é o que dizem as autoras acima. 
Com o objetivo de complementar o perfil do profissional ACS, o Ministério da Saúde propôs diretrizes que ajudam a definir as competências das atividades desenvolvidas pelos ACS.

Compete ao ACS identificar situações de risco, orientação, acompanhamento e educação popular em saúde, desempenhar ações de prevenção, práticas de promoção da vida em coletividade, interações sociais, a partir de uma concepção que define saúde como promoção de qualidade de vida e desenvolvimento de autonomia, integrando serviços de saúde e indivíduos, grupos sociais e população ${ }^{14}$.

Cada competência atribuída para o ACS expressa uma dimensão do trabalho desse profissional, representando um eixo de sua prática, a qual incorpora três dimensões de saber: saber-conhecer, saber-ser e saber-fazer, expressas no conhecimento, habilidade e atitude. A competência saber-ser é considerada transversal a todas as demais, podendo ser expressa pela capacidade crítica, reflexiva e de mudança ${ }^{14}$.

São cinco as competências descritas pelo Ministério da Saúde: integração da equipe de saúde com a população local; planejamento e avaliação; promoção da saúde; prevenção e monitoramento de risco ambiental e sanitário; e prevenção e monitoramento a grupos específicos e morbidade. Todas essas competências necessitam de habilidades (saber fazer) e conhecimentos (saber) para serem executadas $^{14}$.

Analisando a competência de Promoção da Saúde de forma mais específica, pode-se entender que esta enfatiza a melhoria da qualidade de vida da população, a gestão social das políticas públicas de saúde e o exercício do controle do setor saúde pela sociedade, através de ações que buscam o conhecimento do processo saúdedoença, risco social, indicadores de saúde, conceito e estratégias da promoção da saúde, os principais problemas de saúde da população, interssetorialidade, cultura popular, participação e mobilização social, lideranças, portadores de necessidades especiais e estatutos ${ }^{14}$.

Além do perfil de competências já descrito pelo Ministério, recentemente a lei $\mathrm{n}^{\mathrm{o}}$ 11.350, de 5 de outubro de 2006, define as atividades do ACS e do Agente de Combate de Endemias, sendo que, nos termos dessa lei, o vínculo empregatício deve se dar de forma direta e não terceirizada, como vem acontecendo. Dentre as atribuições descritas para o ACS, há atividades ligadas à prevenção de doenças, 
promoção da saúde através de visitas domiciliares, ações comunitárias, individuais ou coletivas, sendo que estas devem ser desenvolvidas conforme as diretrizes do SUS ${ }^{15}$

Entre as atividades preconizadas, há:

I- a utilização de instrumentos para diagnóstico demográfico e sóciocultural da comunidade;

II- $\quad$ a promoção de ações de educação para a saúde individual e coletiva;

III- o registro, para fins exclusivos de controle e planejamento das ações de saúde, de nascimentos, óbitos, doenças e outros agravos à saúde;

IV- $\quad$ o estímulo à participação da comunidade nas políticas públicas voltadas para a área da saúde;

V- a realização de visitas domiciliares periódicas para monitoramento de situações de risco à família; e

VI- a participação em ações que fortaleçam os elos entre o setor saúde e outras políticas que promovam a qualidade de vida ${ }^{15}$.

Para exercer a atividade de ACS, a pessoa necessita residir na área da comunidade em que vai atuar, desde a data da publicação do edital do processo seletivo; ter concluído com aproveitamento o curso de introdução de formação inicial e continuada e ter concluído o ensino fundamental ${ }^{15}$.

Ao se analisar as potencialidades desse novo profissional (o ACS) na Atenção Básica, percebe-se ser ele a peça fundamental no envolvimento da população para o enfrentamento dos problemas de saúde, sobretudo para a modificação das condições de vida. A dimensão comunitária desse novo trabalhador assume uma importância muito grande e é o aspecto que pode auxiliar na mudança de enfoque para a construção de um novo modelo de atenção à saúde ${ }^{13}$.

Frente a essas definições apresentadas, como estruturar o trabalho do ACS no paradigma da Promoção da Saúde?

\subsection{O RETRATO DO TRABALHO DO ACS E SUA RELAÇÃO COM} A PROMOÇÃO DA SAÚDE 
A publicação bibliográfica sobre o ACS teve inicio em 1996, sendo que a maior parte da produção se encontra entre os anos de 2001 e 2005, mostrando ser assunto de recente interesse. Na produção brasileira sobre ACS, destaca-se 53,6\% presente nos livros, seguida pelos artigos em periódico - 32,1\%; teses de doutorado e monografias - 7,2\%, e o restante, em dissertações de mestrado - 7,1\%. Em relação à inclusão das referências na base de dados, 59\% foram incluídas a partir de 2000, existindo um predomínio do delineamento experimental em $73 \%$ da produção encontrada e que os objetivos mais frequentes se relacionam com a caracterização do ACS e suas funções ${ }^{16}$. Tudo isso mostra uma busca pela construção de um "que fazer" para esse profissional de saúde, uma vez que o que se teme é que ele seja uma reedição do "Atendente de Enfermagem".

Alguns autores discutem as propostas de formação do ACS, regulamentação da prática profissional e vinculação institucional desses trabalhadores. Concordam que o trabalho do ACS se mantém como ponte entre a instituição de saúde e comunidade, através de um breve histórico sobre a trajetória do seu trabalho até os dias de hoje na Estratégia de Saúde da Família (ESF). Abordam a questão da ambiguidade do trabalho do ACS. Afinal, pretendia-se que a prática deste profissional mantivesse o diálogo entre o conhecimento de caráter popular com o conhecimento científico apreendido no processo de formação e capacitação proposto. A realidade, porém, mostra uma submissão desqualificadora dos saberes populares aos saberes clínicos advindos do conhecimento científico ${ }^{8}$.

Analisando a questão do processo de capacitação e educação, percebe-se que a transformação desses agentes em sujeitos proativos deve ser objetivo central dos programas de capacitação. Os ACS deveriam ser capacitados sobre os diferentes aspectos do processo saúde-doença, porém o que se verifica é um método pautado no modelo tradicional flexneriano, que enfoca mais os aspectos biológicos, de forma fragmentada e reparadora, não contemplando a participação comunitária para a transformação dos determinantes de saúde ${ }^{17}$.

O que se pode observar é que a maioria dos trabalhadores da ESF comunga da mesma ótica acima, e são eles que estão capacitando os ACS. Para um melhor desenvolvimento das habilidades e potencialidades dos ACS, é preciso priorizar as necessidades destes e da comunidade, através da construção de um projeto de educação para ensinar a ensinar, ou seja, uma prática educativa problematizadora ${ }^{17}$. 
Além da discussão do processo de formação e capacitação do ACS, outra discussão bastante interessante é a respeito do seu trabalho e seu papel de mola propulsora para consolidação do SUS, para a organização das comunidades e a prática regionalizada e hierarquizada de assistência, e para a estruturação dos distritos sanitários. Duas dimensões de atuação desse profissional são propostas: técnica e política. O componente técnico se relaciona ao atendimento aos indivíduos e famílias, com o objetivo de prevenção de agravos ou monitoramento de grupos ou problemas específicos. No componente político, explora-se o ACS como um elemento de reorientação da concepção e do modelo de atenção à saúde, que apoia o autocuidado, fomenta a cidadania e a transformação social. Assim, percebe-se a necessidade de levar em conta outras dimensões na discussão das expectativas de atuação do ACS e dos desafios para o "novo" perfil desse profissional, como mecanismos de seleção, processos de capacitação (treinamento introdutório e educação continuada) e a sistemática da supervisão adotada ${ }^{17}$.

Tomando-se como base o objetivo do PACS, o ACS aparece como educador para saúde, pois organiza o acesso, capta necessidades, identifica prioridades e detecta os casos de risco. Ao tender para o polo técnico, a equipe, exercendo sua função de gerência, aparenta não ver as atribuições desses dois polos de atuação, ou até mesmo direciona o ACS mais para um ou outro. Existem desafios para atuação do ACS, confirmados pela realidade que se enfrenta hoje, ao observar o trabalho da equipe de saúde da família e, em especial, do $\mathrm{ACS}^{8}$.

Se o que se busca é implantar uma oferta de ações de forma organizada, é preciso conformar o saber, os instrumentos e as formas de atuar, através de uma equipe que integre o projeto de trabalho com vistas à promoção da saúde e que se articule com outros equipamentos e movimentos sociais. Destaca-se novamente crítica à formação da equipe multiprofissional que compõe a ESF. Afinal "Quais seriam as estratégias para o desenvolvimento do trabalho do agente comunitário?" 8.

Discorrendo ainda sobre o trabalho do ACS, uma categorização importante é discutida em uma pesquisa que tem como objetivo analisar a vulnerabilidade e o sofrimento referido pelo ACS no cotidiano do seu trabalho, identificados através do que significa ser ACS e sua percepção em relação à organização do trabalho. A análise da pesquisa se deteve mais no campo da vulnerabilidade, destacou oito categorias, sendo uma contribuição significativa à discussão do sentimento de 
onipotência do ACS, que sente poder resolver os problemas dos usuários, embora, ao mesmo tempo perceba existir coisas que vão além de sua governabilidade, frustrando expectativas e criando uma esperança no usuário, que, às vezes, não corresponde à realidade ${ }^{18}$.

Já em relação ao significado que o ACS atribui ao seu trabalho na construção do SUS, é possível verificar, conforme sua concepção, duas vertentes: a de ajudar e a de estar empregado, com um matiz positivo, pois ambas são desenvolvidas na comunidade. Quando aprofundado qual o conceito de ajuda, este a define como caridade e orientação, porém ele não percebe o poder de transformação que pode exercer enquanto agente de mudança ${ }^{19}$.

Já a vertente definida como estar empregado se mostra muito importante, pois a escassez de emprego na região é alta, o ACS se sente satisfeito em poder unir uma ação que garanta seu sustento ao prazer de trabalhar no que gosta, com a comunidade $^{19}$.

No tange ao SUS, PACS E ESF, os trabalhadores desconhecem os princípios que os regem, entendem ser o elo entre serviço de saúde e comunidade, mas também veem o SUS como algo gratuito e não conseguem ver a relação existente entre PACS e SUS ${ }^{19}$.

No que se relaciona ao trabalho, o ACS entende como tarefas que deve desempenhar o agendamento de consultas, a entrega de remédios, o acompanhamento de crianças e gestantes e a orientação em relação à saúde. O ACS não tem consciência da dimensão do trabalho que pode realizar, e suas ações ainda estão distantes do que se pode caracterizar como ações de promoção da saúde, conforme proposto pelo Ministério da Saúde e definido pela Carta de Ottawa ${ }^{19}$.

Em alguns momentos o ACS apresenta um duplo papel para a comunidade: o de ser a voz da população e a presença do Estado, o que mostra uma obscura relação entre este profissional e os demais componentes da equipe de saúde ${ }^{20}$.

Em um estudo realizado em Porto Alegre desta-se as principais atividades desenvolvidas pelos ACS. A principal é a visita domiciliar, seguida pela educação em saúde. As orientações mais comuns referem-se a cuidados de higiene, calendário vacinal, cuidados com recém-nascidos, puérperas e gestantes, além do uso correto das medicações ${ }^{21}$ 
Já em relação à percepção dos profissionais da equipe de saúde, destacam-se as atividades de acompanhamento de idosos, crianças, gestantes, puérperas, grupos de risco, formação de grupos, controle vacinal, cadastramento de famílias e a busca ativa de faltosos. Além dessas atividades destacadas, percebe-se também o ACS desempenhando atividades administrativas de apoio, como atuar na recepção, agendar consultas, organizar prontuários, controlar almoxarifado e o preenchimento das fichas do Sistema de Informação da Atenção Básica (SIAB), porém estas são as menos apreciadas ${ }^{21}$.

Quando se avalia o relato dos ACS e da equipe de saúde, percebe-se que estes trabalham na ótica da prevenção de doenças e não da promoção da saúde; que exercem atividades pontuais, que reforçam o conceito de saúde como ausência de doenças. Não consideram a influência da inserção social do usuário no processo de adoecimento, muito menos planejam ações baseadas nas necessidades dos diferentes grupos sociais $^{21}$.

Ao se trabalhar na concepção do processo saúde-doença socialmente determinado, torna-se possível entender todo o contexto que leva o sujeito a adoecer. É de extrema importância que os profissionais que desempenham a função de ACS tenham esse entendimento, para que possam desempenhar o que propõe o Ministério da Saúde.

Outro ponto a ser discutido se relaciona à avaliação da capacitação dos enfermeiros em relação às atividades desenvolvidas junto aos ACS. Afinal, o sucesso não depende somente do ACS, mas também das ações baseadas nos levantamento de prioridades analisadas por todos os membros da equipe, da colaboração dos gestores e da disposição da equipe para mudanças ${ }^{22}$.

Após a avaliação de toda essa discussão trazida por estes diferentes autores, fica o questionamento: apenas atribuir aos ACS as ações de Promoção da Saúde garante que estas sejam realizadas?

Em uma dissertação de mestrado sobre o ACS, observa-se uma discussão bastante importante referente ao seu trabalho e a promoção da saúde, pode-se confirmar através da pesquisa, que as atividades voltadas ao fortalecimento individual e coletivo não fazem parte do cotidiano do ACS, algo facilmente observado na prática desse profissional ${ }^{23}$. 
Entre as ações preconizadas pelo Ministério da Saúde, prevalece a competência de prevenção e monitoramento a grupos específicos e morbidade. Este se baseia em ações de orientação individual e familiar e acompanhamento de morbidade, mediante os grupos de prioridade. Essas ações se destacam por terem cunho muito mais relacionado à parte administrativa do trabalho do ACS, que se traduz pela coleta de dados e posterior lançamento em planilhas que irão medir sua produtividade, dados estes exigidos pelo Ministério para avaliar o desempenho da unidade para geração de recursos financeiros ${ }^{23}$.

Essa forma de avaliação de produtividade implica, muitas vezes, num trabalho "automático", vinculado à cobrança da gerência e da Secretaria de Saúde, sem que o ACS aproveite tal momento para refletir sobre sua prática e sobre os resultados que tem (ou não) conquistado.

Para que mudanças relativas à concepção de Promoção da Saúde aconteçam, a autora destaca a necessidade de criação de momentos em grupo com toda a equipe, para que haja reflexão, planejamento e avaliação quanto às ações de promoção desenvolvidas por esta. Para tanto, são necessários instrumentos que subsidiem essas discussões, além de apoio técnico para construção de ações que promovam a saúde individual e coletiva ${ }^{23}$.

A pesquisa mostra que o entendimento dos ACS de Promoção da Saúde se encontra baseado no conceito de Levell e Clarck (1979) e não ao relacionado à Carta de Ottawa, o que leva o ACS a priorizar muito mais as ações de prevenção. Dessa forma, é de extrema importância a capacitação da população em relação à identificação de suas necessidades de saúde para o alcance de mudanças no setor saúde de forma equitativa ${ }^{23}$.

Percebe-se a necessidade de mudança do foco de atuação, já que os estudos discutidos nesse artigo mostram que, de fato, o ACS não realiza o preconizado. Talvez se faça necessária a implementação de outra forma de supervisão do seu trabalho, para possibilitar o aprendizado construtivo, baseado no levantamento de suas necessidades, além de fazê-lo refletir sobre sua prática de trabalho. Mas não se pode esquecer a equipe; afinal, não basta somente uma parte desta trabalhar nessa ótica, é preciso estarem todos os membros envolvidos no processo. 


\subsection{ACS E PROMOÇÃO DA SAÚDE: ISSO É POSSÍVEL?}

No início, a avaliação do trabalho em saúde se relacionava principalmente à prática médica, sendo o objeto dessa prática o cuidado. Gradativamente outros conceitos foram introduzidos ao termo trabalho em saúde, produzindo uma definição mais abrangente, pois contemplava toda a equipe de saúde ${ }^{24}$.

A diferença presente no conceito trabalho em saúde está relacionada ao homem (compreendido na sua subjetividade) ser o objeto desse processo. Com o Capitalismo, essa relação do homem com o processo de trabalho é modificada, o corpo humano representa a força de trabalho a ser vendida. Consequentemente, surge a necessidade de um cuidado mais específico dessa "ferramenta" de trabalho ${ }^{24}$.

Desta forma, há uma maior preocupação com a doença e a rápida recuperação da força de trabalho, para que não haja prejuízo da parte empregadora. As práticas de saúde, nesse contexto, se dividem em: modelo epidemiológico, que aborda a doença no seu contexto coletivo; e o modelo clínico, que focaliza a doença no seu contexto individual $^{24}$.

No trabalho em saúde, o produto final de todo o processo resulta em algo não concreto, mas que pode interferir na vida dos diferentes grupos sociais, por possuir diversos significados, que resultam na assistência de saúde. O trabalho em saúde é resultado de uma ação conjunta, reflexiva e intersubjetiva realizada pelos diferentes componentes da equipe de saúde, em especial o $\mathrm{ACS}^{24}$.

Com base nas análises que sistematicamente foram realizadas sobre o trabalho do ACS, o Ministério da Saúde considerou as singularidades e especificidades do trabalho deste profissional e construiu um programa de formação, no qual foram definidas as competências que deveriam compor o perfil profissional do ACS. Conceituou-se como competência profissional a capacidade de enfrentar situações e acontecimentos específicos no trabalho, com iniciativa e responsabilidade, segundo um raciocínio prático sobre o que está acontecendo e com capacidade para coordenar-se com outros atores para a mobilização de suas capacidades ${ }^{14}$. 
Em uma pesquisa realizada em São Bernardo do Campo sobre o ACS, outra discussão importante sobre o trabalho do ACS na Promoção da Saúde é feita. Foi explorada a concepção do ACS sobre as competências atribuídas a esse profissional pelo Ministério da Saúde ${ }^{25}$.

A autora mostrou que em relação à execução das ações relativas à competência de integração da equipe de saúde com a população local, 43,5\% realizam essa atividade diariamente, o que mostra que o ACS compreende essa ação proposta pelo Ministério e se sente o elo entre o serviço e comunidade. A base para o desenvolvimento de suas ações se dá através da visita domiciliar, visto que $82,6 \%$ dos ACS realizam-na. Além disso, 74,3\% orientam a comunidade sobre o funcionamento da unidade, atividades e campanhas e $66,4 \%$ orientam as ações desenvolvidas pelos serviços de saúde ${ }^{25}$.

Uma preocupação se apresenta em relação à participação do ACS na reunião de equipe, pois são raros os que expõem suas opiniões em reunião de equipe, apenas $38,6 \%$ dos entrevistados. A autora salienta que, agindo assim, o ACS falha com a equipe, ao não explicitar sua percepção sobre o modo de vida da comunidade e, talvez, falhe com a comunidade, reproduzindo lá o que é solicitado pela equipe, atitude que pode levá-lo a se afastar do polo comunitário. Nas entrevistas, apenas 11,6\% dos entrevistados disseram levar diariamente para a equipe as necessidades da comunidade que julgam pertinentes. E 9,5\% dos ACS pesquisados raramente tomam essa atitude, o que mostra diferentes inserções e equipes que dão pouca abertura a esse profissional ${ }^{25}$.

O ACS se apresenta como elo entre a equipe e comunidade, porém não consegue traduzir as necessidades da comunidade para a equipe, talvez pela visão biologicista em que foi formado ou por se sentir pouco importante diante dos demais profissionais $^{25}$.

Analisando de forma específica a Promoção da Saúde, 35,1\% dos ACS realizam essa atividade diariamente e $11,8 \%$ nunca a realizam, o que mostra diferentes condutas nas equipes; 79,3\% estimulam o autocuidado, 71,4\% estimulam a população que acompanham a refletir sobre suas condições de saúde-doença, e 56,8\% raramente executam ações em parcerias com outras secretarias existentes ${ }^{25}$.

A autora ainda aponta para formulação de políticas de educação permanente que possam capacitar enfermeiros e ACS, para que haja uma padronização das práticas 
do PACS, contribuindo para a implementação dos SUS e reverter a lógica centrada na especialidade ${ }^{25}$.

O estudo aponta que o referencial da Promoção da Saúde pode ser importante para viabilizar a mudança do modelo de assistência à saúde. Há subsídios teóricos para direcionar o trabalho do ACS numa visão de saúde mais ampliada. Assim sendo, o trabalho do ACS é visto como algo específico e não uma alternativa de baixo custo para expansão da cobertura de saúde ${ }^{25}$.

Outra discussão interessante sobre o trabalho do ACS e a Promoção da Saúde também é feita em uma dissertação que retrata as ações realizadas por ACS que trabalham na região central de São Paulo. Através desta pesquisa, pode-se confirmar que as atividades voltadas ao fortalecimento individual e coletivo não fazem parte do cotidiano deste profissional ${ }^{23}$.

Frente aos questionamentos apresentados, como estruturar o trabalho do ACS no Paradigma da Promoção da Saúde, visto que o que se deseja é a construção de uma assistência integral e integrada, que articule as esferas do cuidado, da assistência e da prevenção? 
OBJETIVOS 


\section{OBJETIVOS}

A partir do trabalho que o ACS desempenha dentro da dinâmica do SUS, seja em UBS ou em USF, este projeto de pesquisa tem como objetivos centrais:

- Caracterizar o ACS que atuam na Atenção Básica no município de Marília,

- Descrever as ações do ACS no município de Marília e,

- Analisar as ações realizadas pelo ACS nas equipes de Saúde da Família na perspectiva da sua potencialidade para a promoção da saúde, mais especificamente, para o fortalecimento da comunidade. 
BASES TEÓRICAS DA INVESTIGAÇÃO 


\section{BASES TEÓRICAS DA INVESTIGAÇÃO}

\subsection{ALGUNS ASPECTOS CONCEITUAIS DA PROMOÇÃO DA SAÚDE}

Na década de 1940, o conceito de Promoção da Saúde tradicionalmente difundido foi o definido pelo modelo de Leavell e Clarck (1979), representado pelo esquema da História Natural das Doenças, baseado nos elementos primários da medicina preventiva. Com o passar dos anos, o conceito foi se modificando, em função de novas correntes de Promoção da Saúde, que surgiram no Canadá, Estados Unidos e Europa Ocidental $^{26}$.

Ao analisar o histórico das conferências de Promoção da Saúde, percebe-se como este conceito foi se diferenciando e ampliando sua proposta, partindo do conceito voltado apenas para processos educativos e de mudança do estilo de vida no âmbito individual, para um conceito mais abrangente, que enfoca o aumento do controle por indivíduos e grupos sobre os determinantes de saúde ${ }^{26}$.

O movimento da promoção da saúde teve seu início no Canadá, em 1974, com a divulgação do Informe Lalonde, cuja motivação central era o enfrentamento aos custos crescentes da assistência médica e o questionamento dos limites da abordagem exclusivamente médica para doenças crônicas. Entretanto, somente na década de1980, a promoção da saúde ganhou destaque no campo da Saúde Pública, após introdução do conceito de forma oficial pela Organização Mundial da Saúde (OMS) ${ }^{28,29}$.

Como estratégia de ação e enfrentamento, o Informe Lalonde dividia o campo da saúde em quatro componentes: biologia humana, ambiente, estilo de vida e organização dos serviços de saúde. O maior enfoque se dava na mudança dos estilos de vida, sob o prisma individual, comportamental e preventivo. Diversas críticas foram feitas a esse documento, principalmente no que se referia à ênfase das intervenções unilaterais sobre os estilos de vida, intervenções essas que tiveram 
impacto pouco satisfatório sobre as condições de vida da população marginalizada ${ }^{27,30}$

Já no que se refere à definição de Promoção da Saúde, esta parte de uma concepção vasta do processo saúde-doença e seus determinantes, propondo uma integração entre saberes técnicos e populares, juntamente com a mobilização de recursos institucionais e comunitários, públicos e privados, em busca de uma forma de resolução e enfrentamento dos problemas ${ }^{31}$.

Em 1986, a $1^{\text {a }}$ Conferência Internacional sobre Promoção da Saúde teve como principal produto a Carta de Ottawa, que define promoção da saúde como "o processo de capacitação da comunidade para atuar na melhoria da sua qualidade de vida e saúde, incluindo uma maior participação no controle deste processo" ${ }^{\text {, }}$.

A Carta de Ottawa se apresenta como um documento de referência para a Promoção da Saúde, conforme relata o Ministério da Saúde. Ela propõe cinco estratégias centrais de ação: elaboração e implementação de políticas públicas saudáveis; criação de ambientes favoráveis à saúde; reforço da ação comunitária; desenvolvimento de habilidades pessoais e reorientação dos sistemas e serviços de saúde $^{30}$.

O conceito de Promoção da Saúde, hoje vigente, recebeu contribuição significativa da Carta de Ottawa, por associá-lo a um conjunto de valores como vida, saúde, solidariedade, equidade, democracia, cidadania, desenvolvimento, participação e parceria. Traz a combinação entre ações do Estado, comunidade, indivíduos, sistema de saúde e parcerias interssetoriais, o que caracteriza a responsabilização múltipla, em relação aos problemas e soluções ${ }^{31}$.

As conferências internacionais seguintes não apenas reafirmaram os cinco eixos de atuação já apresentados na Carta de Ottawa, mas ampliaram diversos temas. A Conferência de Adelaide, 1988, tinha como tema central as políticas públicas voltadas para a saúde. Quatro áreas foram priorizadas: saúde da mulher; alimentação e nutrição; tabaco e álcool; e criação de ambientes favoráveis ${ }^{26}$.

Em Sundsval (Suécia), 1991, o enfoque maior se deu em relação à criação de ambientes favoráveis à saúde. $\mathrm{O}$ documento sugere o engajamento dos diversos seguimentos sociais em ações que favoreçam o desenvolvimento de ambientes físicos, sociais, econômicos e políticos adequados à saúde. Para isso, quatro aspectos 
necessitam ser englobados: dimensão social, dimensão política, dimensão econômica e o reconhecimento da capacidade e conhecimento dos grupos ${ }^{26}$.

A Conferência de Jacarta, 1997, foi a primeira a convidar pessoas do setor privado para discutir os problemas. O documento final resgata a discussão sobre a ação comunitária, destacando que a Promoção da Saúde precisa ser realizada junto à população, possibilitando a participação desta na tomada de decisão ${ }^{26}$.

No México, em 2000, a quinta Conferência deu ênfase à importância de ações de promoção da saúde em nível local, nacional e internacional, através dos programas e políticas governamentais, confirmando a necessidade de ações intersetoriais ${ }^{26}$.

A última conferência internacional, até o momento, ocorreu em 2005, em Bangkok. O documento enfatizou a necessidade de mudanças no contexto de saúde global. Essa conferência apontou para as iniquidades geradas a partir da globalização da saúde, para a urbanização acelerada e a degradação do ambiente ${ }^{26}$.

Outras conferências aconteceram de forma regional, enfatizando problemas específicos de alguns países das Américas e Europa: Santa Fé de Bogotá (1992): necessidade de criação de estratégias para promoção da saúde na América Latina; Caribe (1993): reforça a promoção da saúde e propõe estratégias; Canadá (1996): destaque para um novo discurso em saúde, com objetivo de reorientação das estratégias de promoção da saúde; Genebra (na Suíça) (1998): enfatiza melhorias na base de informação da promoção, desenvolvimento em saúde, interssetorialidade e distribuição de recursos para a saúde ${ }^{26}$.

Ao analisar a definição de promoção da saúde, proposta na carta de Ottawa, um eixo em especial se destaca: a questão do empowerment. O conceito de empowerment ainda é ambíguo e, até o momento, seu significado não obteve tradução fidedigna em português. Sua origem está no movimento feminista e na ideologia da ação social em meados do século XX; recebeu também influência dos movimentos de auto-ajuda, psicologia comunitária e movimentos de cidadania ${ }^{27}$.

É preciso atenção no uso desse termo, devido à carência de embasamento teórico, além da dificuldade de tradução nos idiomas português e espanhol, pois considera-se como sinônimo de empowerment, empoderamento, apoderamento, emancipacion, palavras estas com significados distintos do que realmente se define 
como conceito de empowerment ${ }^{1}$. Desta forma, diversos autores optam por manter o termo original $^{27}$.

\subsection{FORMULAÇÕES TEÓRICO-CONCEITUAIS PARA A PESQUISA EM PROMOÇÃO DA SAÚDE}

O livro Theory in a nutshell: a practical guide to health promotion theories, forneceu subsídios para este estudo em relação a intervenções no âmbito da Promoção da Saúde. No prefácio, os autores apresentam o motivo para escrever sobre as teorias que fundamentam a promoção da saúde. Esta nasceu da constatação de que, na realidade, nem todos os programas de promoção da saúde dão bons resultados. Essa realidade apontava ainda que os programas de promoção mais exitosos eram aqueles que tinham uma boa compreensão dos determinantes dos problemas de saúde, aqueles que direcionavam seu foco (e eram motivados) para as necessidades de saúde da população alvo e aqueles que compreendiam amplamente o contexto (político, social e de saúde) no qual que o programa estava sendo desenvolvido ${ }^{33}$.

O livro aponta que a utilização de referenciais teóricos adequados na construção e na implantação de programas de promoção da saúde pode ajudar a alavancar o programa de diversas formas, tais como: levando a equipe a entender melhor a natureza do problema que se quer enfrentar; a descrever e explicitar as necessidades e motivações da população que se toma como objeto; a fazer proposições mais adequadas sobre como mudar o perfil de saúde, agindo na mudança de comportamentos e de determinantes e, informando-a sobre métodos e medidas para monitorar problemas e programas de intervenção ${ }^{33}$.

A proposta teórica para as mudanças nas práticas de saúde comunitárias baseia-se no fato de que a saúde pode ser influenciada por diversos fatores. Assim, os comportamentos ligados à sua proposição podem ser traçados por estruturas sociais e pelo ambiente social em geral, pois as pessoas se sentem ligadas ao meio onde

\footnotetext{
${ }^{1}$ Tradução termo empower: dar a alguém a autoridade legal ou o poder de fazer algo. Cambridge dictionary of american english 1999, editado por Sidney I. Landau, Nova York, EUA ${ }^{51}$.
} 
vivem. Quando se busca mudanças de comportamentos, é preciso entender o impacto que as estruturas sociais podem exercer, antes de se buscar (através programas ou ações de Promoção da Saúde) realizar mudanças comportamentais, objetivando comportamentos mais saudáveis. Por isso, as práticas de promoção da saúde para as comunidades devem ser implementadas através de um sistema dinâmico, com utilização de estratégias próprias, e possuirem capacidade de influenciar na melhoria da qualidade de vida de tais comunidades ${ }^{33}$.

O trabalho com comunidades locais ou comunidades de interesse (ex. grupos indígenas, grupos de gays, etc.) tem sido uma estratégia central da promoção da saúde, para aprimorar os perfis de saúde ou para resolver um problema especifico; "organização comunitária" é definida como o processo pelo qual grupos comunitários são "ajudados" a identificar problemas comuns e objetivos, mobilizar recursos e, de alguma forma, desenvolver e implementar estratégias para atingir os objetivos coletivamente construídos. Diversas estratégias para a organização comunitária já foram utilizadas, dentre elas, se destaca a tipologia proposta por Rothman (2001), que identifica três modelos de atuação: desenvolvimento local, planejamento social e ação social ${ }^{33}$.

O desenvolvimento local prioriza a participação comunitária e suas formas de promover a autonomia. É um processo que se baseia no consenso e capacidade de construção comunitária para definir e solucionar problemas da comunidade; o profissional de saúde, neste modelo, assume o papel de facilitador do processo, e não o de líder ${ }^{33}$.

Já o planejamento social define-se por uma tarefa autodirigida e orientada, baseada em uma aproximação empírica-racional da definição de problema. Envolve a participação profissional no planejamento de soluções que possam atingir a epidemiologia dos problemas de saúde ${ }^{33}$.

O modelo de ação social caracteriza-se pela união do desenvolvimento local e planejamento social, construído pela capacidade comunitária e implementação de mudanças na comunidade em favor das desvantagens. A base desse processo é o deslocamento de poder nas relações e recursos, sendo que o profisssional de saúde desempenha o papel de defensor e mediador dos conflitos ${ }^{33}$.

Assim, a tipologia proposta por Rothman (2001) deixa claro que nenhum dos modelos é exclusivo, e enfatiza que a mobilização comunitária pode tender para um 
ou, até mesmo, para os três modelos propostos. Algumas críticas foram feitas em relação ao uso do termo desenvolvimento local, pois este implica em um modelo de organização comunitária aplicável somente para comunidades geograficamente definidas. Uma alternativa sugerida seria a utilização do termo desenvolvimento comunitário, pois, quando se pensa em organização comunitária, entende-se algo que reúne o individual, grupos comunitários, trabalhadores da saúde e líderes comunitários, sendo esta uma estrutura favorável para que intervenções sejam planejadas e implementadas em diversos níveis, ou seja, a base de atuação seria a interssetorialidade ${ }^{33}$.

Tal tipologia também é criticada quanto a apresentar falhas no que se refere à necessidade de ajuda e suporte profissional para o desenvolvimento de abordagens de problemas, além da falha na construção da capacidade das comunidades e no incentivo ao empowerment comunitário. A diferença no conceito de organização comunitária, proposto por Rothman(2001), e construção comunitária, proposto por Minkler(1999), está no conceito de empowerment e construção de capacidade. Minkler define empowerment como um processo de ação social em que o individuo, comunidade e organizações ganham o domínio sobre suas vidas no contexto de mudança de seu envolvimento social e político, para melhorar a equidade e qualidade de vida. O empowerment se torna um recurso fundamental, que pode ser usado em diversas situações na melhoria de oportunidades para a saúde ${ }^{33}$.

Ao pensar na avaliação do empowerment desenvolvido pelas comunidades, Rissel (1994), propõe o empowerment contínuo, que ajuda a diferenciar entre os estágios de desenvolvimento do empowerment, tanto aplicável a indivíduos como a comunidades:

$\rightarrow$ os profissionais de saúde podem trabalhar com pessoas, de forma a aumentar sua autoconfiança na capacidade de gerar mudanças;

$\rightarrow$ o envolvimento em grupos de suporte mútuo, autoajuda ou construção de grupos de ação e expansão de redes sociais, que forneça oportunidades para favorecer o desenvolvimento social ${ }^{33}$.

Nesse processo, as pessoas aprendem novas habilidades, com as quais capacitam-se para utilizá-las em outras situações, além de construir a capacidade das comunidades, de resolver seus problemas. Quando a comunidade se torna mais 
"empoderada" (fortalecida), é possível uni-la para se trabalhar com problemas mais específicos e, assim, obter ações mais engajadas política e socialmente ${ }^{33}$.

A capacidade comunitária se define pela capacidade das comunidades em identificar, mobilizar e chamar a atenção para problemas sociais e de saúde pública. A exemplo disso, pode-se observar o trabalho desenvolvido pelos líderes comunitários, que compartilham informações para a resolução de problemas identificados na comunidade, conforme aponta Goodman e colaborares ${ }^{33}$.

Ao se pensar na capacidade comunitária, deve-se entender o seu desenvolvimento e dominar instrumentos para identificar e monitorar tal desenvolvimento. Assim, o trabalho dos profissionais da saúde no trabalho com a comunidade fica facilitado e interessante, na medida em que são medidos os resultados alcançados, conforme apontam Bush, Dower e Mutch $(2002)^{33}$.

Esses autores identificam quatro domínios da capacidade comunitária:

1) rede de parcerias: são as parcerias entre grupos e organização dentro de uma mesma comunidade; isto inclui a qualidade e a natureza do envolvimento dessa parceria;

2) transferência de conhecimento: define-se como troca de informações dentro de um mesmo grupo, rede ou comunidade;

3) resolução de problemas: é a habilidade de grupos dentro de uma mesma rede ou comunidade de recorrer a métodos já conhecidos para identificar e resolver problemas que possam surgir no desenvolvimento de uma atividade ou programa;

4) infraestrutura: refere-se ao nível de investimento realizado na rede ou grupos, como investimentos em política e protocolos, capital social, humano e financeiro; ao se construir a capacidade comunitária, está-se construindo a sustentabilidade ${ }^{33}$.

Ao se pensar no trabalho na (e com a) comunidade, é preciso atentar para o que foi priorizado por ela como sendo um problema. Mesmo sendo este de baixa relevância epidemiológica, é preciso negociar as diferentes perspectivas e planejar ações efetivas frente às necessidades levantadas ${ }^{33}$. 
Os profissionais na promoção da saúde representam uma figura importante em cada tipo de atividade. Em função de as abordagens terem como base a avaliação das necessidades, bem como o empenho e a capacidade das comunidades, tais profissionais contribuem para o aumento da capacidade comunitária das que são suscetíveis para o alcance da sustentabilidade em longo prazo ${ }^{33}$.

A figura abaixo faz uma síntese das dimensões da organização comunitária e da capacidade de construção. São quatro eixos de atuação que se cruzam e dão a idéia de complementaridade das ações desenvolvidas rumo à Promoção da Saúde. Um dos eixos mostra que as ações tanto podem ser direcionadas à identificação de problemas, como ao fortalecimento das comunidades. Já o outro eixo informa a origem de tais ações, ou seja, da comunidade ou dos serviços de saúde/pessoas especializadas. Ao se pensar na Promoção da Saúde, espera-se que as ações partam da comunidade, no sentido de seu fortalecimento, e não dos serviços de saúde ${ }^{33}$.

Este estudo apoia-se nas teorias sobre Promoção da Saúde propostas nesse livro, mas especificamente as do constructo dois (Teorias que explicam mudanças nas comunidades e ação comunitária para a saúde), para pensar sobre as possibilidades e limites das práticas de promoção da saúde na ESF, a partir do $\mathrm{ACS}^{33}$. 


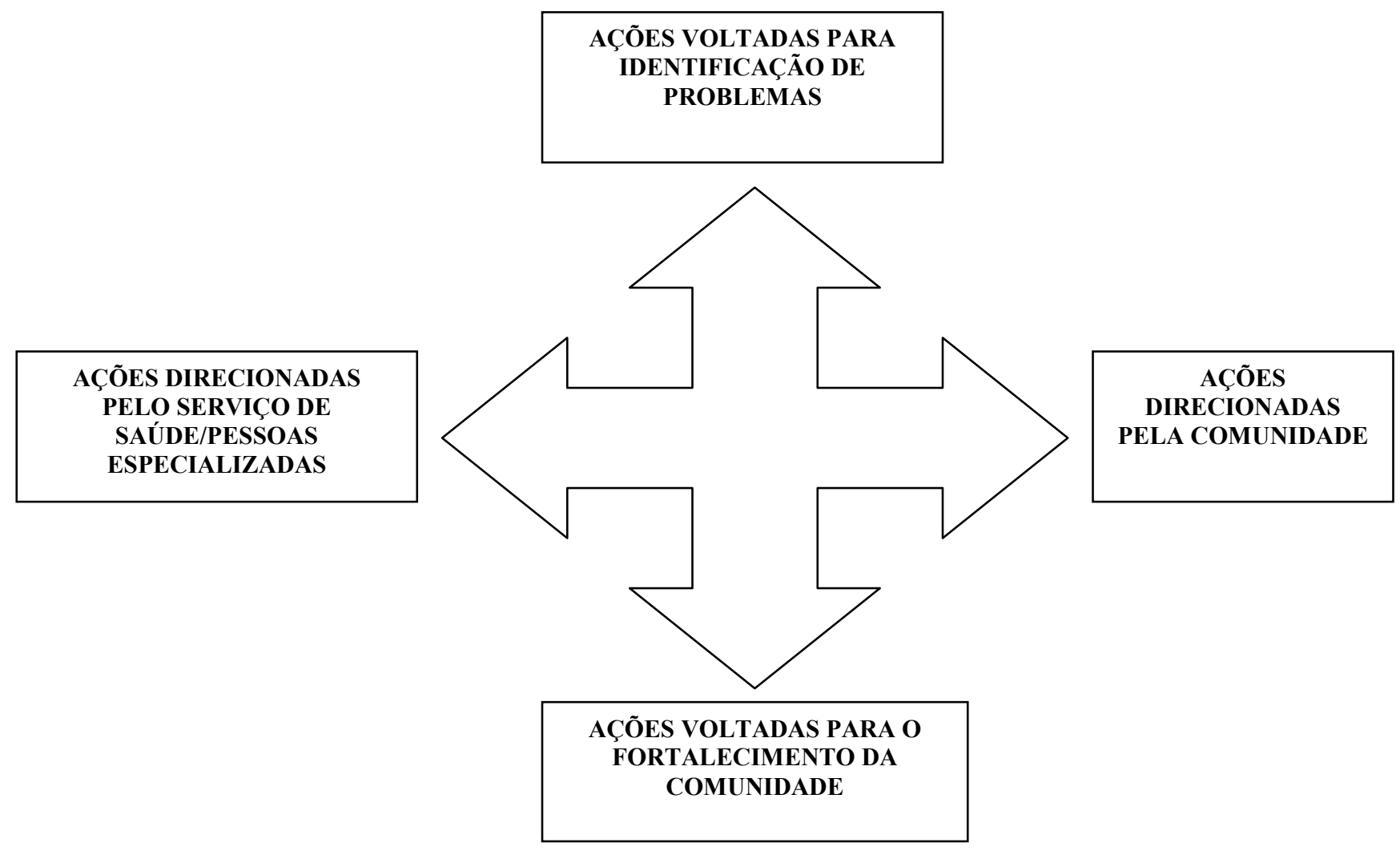

Figura 1- Adaptada de Nutbeam D. Theory in a nutshell: a practical guide to health promotion theories. 2.ed. Austrália: McGraw-Hill; 2004. p.35

Ao final do capitulo três desse livro, pode-se observar que os modelos propostos de organização comunitária não são satisfatórios para o estudo da teoria do desenvolvimento. Não é fácil planejar e controlar todas as variáveis do processo, porém as organizações comunitárias aproximam-se de uma estrutura prática, em que os trabalhadores na promoção da saúde podem se amparar para o planejamento de formas mais efetivas de trabalho com comunidades geograficamente definidas ou grupos de interesse. A abordagem comunitária permite, a esses trabalhadores, identificar o que pode estar além dos determinantes sociais de saúde, e estimular o envolvimento da comunidade na definição e enfretamento de seus problemas ${ }^{33}$.

O empowerment dos indivíduos, grupos e comunidades, mesmo abordado no modelo da organização comunitária, não torna necessário, para os membros das comunidades, a responsabilidade de definir seus problemas ou ter maior responsabilidade no ato de colocar em prática as ações de mudança. É relevante notar que existem críticas ao modelo de organização comunitária por manter seu foco 
apenas nos problemas da comunidade. Assim, a mesma não percebe a força que tem $^{33}$.

A construção comunitária com base no empowerment é bastante atrativa, mas difícil de ser posta em prática. Este processo requer dedicação, alto nível de confiança e compromisso entre os envolvidos e voluntários para o abandono do poder, principalmente pelos trabalhadores da saúde. Existem limitações nos modelos de construção comunitária e capacidade comunitária, pois, ao se focar apenas na necessidade de construção de capacidade comunitária, pode-se, indiretamente, passar às comunidades a responsabilidade de resolução de seus problemas, independentemente das causas. Além disso, mesmo se trabalhando com líderes comunitários, os trabalhadores da saúde podem acrescentar mais poder (empower) aos que já estão "empoderados" e continuar marginalizando aqueles que são desprivilegiados ${ }^{33}$.

Assim, interpretando as Teorias de Promoção da Saúde ${ }^{33}$, precisa-se tomar o cuidado de não transferir toda responsabilidade do processo de fortalecimento das comunidades a um único ator: o ACS. Ela cabe ao conjunto serviço de saúde e comunidade, mediado por aquele que tem o papel de mediar e traduzir os interesses de ambos os lados: o ACS. 
METODOLOGIA 


\section{METODOLOGIA}

\subsection{ASPECTOS METODOLÓGICOS DA PESQUISA}

Ao se definir o objeto de pesquisa, o próximo passo é a seleção da forma de investigação desse objeto. Quando um recorte de uma dada realidade é feito, este representa o campo empírico a ser estudado, denominado campo de pesquisa ${ }^{34}$.

A partir dessas definições, novos conhecimentos podem ser descobertos. $\mathrm{O}$ local de estudo passa a ser o lugar ocupado pelos sujeitos de pesquisa, que convivem dentro de uma dinâmica social de interação, o que torna necessário uma construção teórica para transformar esses grupos em objetos de pesquisa e investigar suas histórias ${ }^{34}$.

$\mathrm{Na}$ busca da aproximação com o objeto de estudo e com o intuito de compreender como os ACS do município de Marília (SP) realizam as ações propostas pelo Ministério da Saúde ${ }^{14}$, e quais são suas potencialidades de efetivação da Promoção da Saúde, partiu-se de um estudo exploratório de caráter descritivo, com uma abordagem do problema de forma quantitativa. Do ponto de vista dos procedimentos técnicos, utilizou-se, para a coleta de dados, um questionário estruturado $^{35}$, aplicado em outras pesquisas com o $\mathrm{ACS}^{23,25}$. Esse questionário é composto por duas partes: a primeira, faz a caracterização do perfil demográfico dos ACS do município de Marília, e a segunda parte avalia a frequência com que as competências propostas pelo Ministério da Saúde ${ }^{14}$ são realizadas.

Conhecer e se aproximar do objeto de estudo no que se refere às ações de Promoção da saúde realizadas pelos ACS estudados remete, também, ao entendimento de como se dá a dinâmica de trabalho das equipes de saúde inseridas na Unidade de Saúde da Família (USF) e na Unidade Básica de Saúde (UBS). Assim, como hipótese desse estudo, tem-se o entendimento de que as ações realizadas pelo ACS estão organizadas de maneira a favorecer o fortalecimento das comunidades em busca de modos de vida saudáveis e mudança nos determinantes sociais. Afinal, 
acredita-se que as equipes de saúde capacitam o ACS para o seu trabalho com base nesses conceitos.

\subsection{CENÁRIO DE ESTUDO: A CONTEXTUALIZAÇÃO DA} HISTÓRIA DE SAÚDE DO MUNICÍPIO DE MARÍLIA NA SUA TRAJETÓRIA DE IMPLEMENTAÇÃO DE UM NOVO MODELO DE ATENÇÃO À SAÚDE.

Juntamente com a mudança do sistema de saúde vigente no século XIX, Marília procurou incorporar as tendências criadas pela nova Constituição federal, de 1998. Naquele momento, a atenção básica de saúde do município contava com 17 UBS, distribuídas conforme os grupos populacionais mais numerosos, realizando atendimentos ambulatoriais a diversas faixas etárias, programáticos e de pronto atendimento. O modelo de atenção à saúde era médico-centrado e a unidade funcionava como porta de entrada no sistema, o que reforçava a procura por atendimento especializado no setor terciário de atenção à saúde. As UBS realizavam as atividades básicas de vigilância epidemiológica, resolviam problemas pontuais e desempenhavam as atividades programáticas preconizadas pelo Governo ${ }^{24}$.

Essa realidade de atendimento sobrecarregava o setor terciário com atendimentos que poderiam ser solucionados pela atenção primária. Por isso, a reorganização dos serviços se mostrava necessária, sendo implementada através da responsabilização da equipe de saúde por um atendimento que realmente contemplava uma abordagem mais ampla.

Frente a isso, a Secretaria Municipal de Higiene e Saúde, hoje Secretaria Municipal de Saúde (SMS) traçou um Plano Municipal de Saúde, que continha as prioridades relacionadas à saúde do município, abrangendo diretrizes, garantindo recursos necessários e, ao final, a avaliação dos resultados alcançados. A proposta feita para as equipes locais de saúde foi a autonomia para organização do processo de trabalho em cada unidade, respeitando os limites pactuados através do Plano Municipal de Saúde ${ }^{36}$.

Todo esse processo de mudança foi realizado em parceria com a comunidade, através de aprovação dos Conselhos Locais de Saúde (CLS), do Conselho Municipal 
de Saúde (COMUS) e a participação ativa destes através de representantes, que acompanharam de perto toda implementação e avaliação dos resultados obtidos ${ }^{24}$.

A SMS propôs mudanças relacionadas ao atendimento do usuário que procurava o serviço de saúde, como a valorização do acolhimento, estabelecimento de vínculo, compromisso e responsabilidade no atendimento prestado. Além disso, iniciou-se a implantação da ESF, de forma a favorecer a mudança no modelo de atenção à saúde ${ }^{24}$.

A princípio, em 1998, apenas duas UBS receberam o PACS. Já no final daquele mesmo ano, quatro Unidades de Saúde da Família (USF) foram implantadas, dando início à trajetória deste modelo de atenção no município de Marília ${ }^{24}$.

Em sequência, outras USF foram surgindo. A demanda reprimida, advinda das UBS e USF, era atendida pelos Pronto-Atendimentos (PA) localizados na Zona Sul e Norte do município. Ao final do ano de 2004, o quadro de unidades de saúde do município já contava com 13 UBS, 25 USF e 100\% de PACS ${ }^{24}$.

A contratação dos funcionários para trabalharem nas USFs era realizada mediante parceria da SMS com instituições como a Maternidade Gota de Leite, a Santa Casa de Misericórdia e o Hospital São Francisco. Todas as contratações obedeceram à Consolidação das Leis Trabalhistas (CLT) mediante aprovação em processo seletivo $^{24}$

Marília é uma cidade localizada no interior do estado de São Paulo, com distância aproximada da capital de $450 \mathrm{~km}$ e fica na região centro-oeste do Estado. Atualmente, existem 225.938 mil habitantes ${ }^{37}$, sendo boa parcela deles formada por estudantes que procuram as universidades, faculdades e as escolas técnicas para aprimoramento do conhecimento e estudo especializado ${ }^{38}$.

A maior fonte de renda gerada no município provém do setor alimentício, visto que existem no município grandes indústrias desse gênero, contribuindo com $12 \%$ da produção nacional de biscoitos ${ }^{26}$. Além do setor alimentício, a indústria local é representada pelo setor metalúrgico, com $27,8 \%$ da produção local; de artigos de vestuário, com 12,2\%; de móveis, com $6,2 \%$; de artefatos de couro, com 2,2\%; produtos de limpeza, com 2,2\%; embalagens, com 1,2\%, e outros, com 21,3\%. Existem na cidade 310 indústrias e 6900 pontos de comércio, com destaque para o setor de bares, lanchonetes, restaurantes, pizzarias e churrascarias ${ }^{36}$. 
O abastecimento de água atinge $98,51 \%$ da população; a coleta de lixo $100 \%$; o esgoto sanitário, não tratado, contempla 96,35\%; a rede de esgoto tratada é de apenas $2 \%$. Não existe no município forma adequada de destino do lixo domiciliar e comercial $^{36,38}$.

A rede pública e particular de ensino (infantil, fundamental e médio) favorece a não ocorrência da evasão escolar: o município possui 36 escolas estaduais, 27 escolas municipais de ensino infantil (EMEI), 16 escolas de ensino fundamental (EMEF), três escolas municipais de ensino fundamental e infantil (EMEFEIs), e quatro berçários. A rede particular conta com 30 unidades entre ensino infantil, fundamental e médio ${ }^{36}$. Existem, ainda, duas unidades de ensino supletivo e duas de ensino supletivo profissionalizante. Já em relação ao ensino superior, Marília conta com duas universidades, um centro universitário e quatro faculdades ${ }^{24}$. O índice de analfabetismo do município em 2000 foi de $5,69 \%{ }^{37}$.

\subsection{CENÁRIO DE ESTUDO: AS ESPECIFICIDADES DO SETOR} SAÚDE

Segundo dados do Instituto Brasileiro de Geografia e Estatística (IBGE), em 2007, o número total de óbitos hospitalares no município de Marília, conforme suas causas foram: 35, por doenças parasitárias e infecciosas; 69, por neoplasias; 21, por doenças endócrinas, nutricionais e metabólicas; 1159, por doenças do aparelho circulatório; 14, por doenças originadas no período perinatal; um, devido a gravidez, parto e puerpério; dois, por malformações congênitas, deformidades e anomalias cromossômicas; 107 , por lesões, envenenamento e causas externas; e nenhum devido a causas externas de morbidade e mortalidade ${ }^{37}$.

O Quadro I abaixo representa o perfil do município apresentado pela Fundação SEADE, conforme o ano, de forma comparativa com o Estado de São Paulo ${ }^{38}$. 
Quadro I - Perfil do Município de Marília em relação ao Estado de São Paulo conforme o ano.

\begin{tabular}{|c|c|c|c|}
\hline TIPO DE DADO & ANO & MARÍLIA & $\begin{array}{l}\text { ESTADO DE SÃO } \\
\text { PAULO }\end{array}$ \\
\hline $\begin{array}{l}\text { Densidade Demográfica } \\
\left(\mathrm{hab} / \mathrm{km}^{2}\right)\end{array}$ & 2008 & 195,71 & 164,54 \\
\hline Grau de Urbanização (\%) & 2007 & 97,26 & 93,75 \\
\hline $\begin{array}{l}\text { Índice de Envelhecimento } \\
(\%)\end{array}$ & 2008 & 54,06 & 43,35 \\
\hline $\begin{array}{l}\text { População com menos de } 15 \\
\text { anos }(\%)\end{array}$ & 2008 & 21,33 & 23,73 \\
\hline $\begin{array}{l}\text { População com } 60 \text { anos ou } \\
\text { mais (\%) }\end{array}$ & 2008 & 11,53 & 10,29 \\
\hline $\begin{array}{l}\text { Taxa de Natalidade (por mil } \\
\text { habitantes) }\end{array}$ & 2006 & 12,07 & 14,92 \\
\hline $\begin{array}{l}\text { Taxa de Fecundidade (Por } \\
\text { mil mulheres entre } 15 \text { e } 49 \\
\text { anos) }\end{array}$ & 2006 & 41,77 & 52,12 \\
\hline $\begin{array}{l}\text { Taxa de Mortalidade Infantil } \\
\text { (por mil nascidos vivos) }\end{array}$ & 2007 & 13,93 & 13,09 \\
\hline $\begin{array}{l}\text { Taxa de Mortalidade da } \\
\text { População entre } 15 \text { e } 34 \\
\text { anos (por mil habitantes) }\end{array}$ & 2006 & 104,25 & 130,41 \\
\hline $\begin{array}{l}\text { Taxa de Mortalidade da } \\
\text { População com } 60 \text { anos ou } \\
\text { mais (por mil habitantes) }\end{array}$ & 2006 & 3550,66 & 3820,17 \\
\hline $\begin{array}{l}\text { Mães adolescentes (com } \\
\text { menos de } 18 \text { anos, em \%) }\end{array}$ & 2006 & 6,92 & 7,59 \\
\hline $\begin{array}{l}\text { Mães que tiveram } 7 \text { e mais } \\
\text { consultas de pré-natal }(\%)\end{array}$ & 2006 & 92,41 & 74,89 \\
\hline
\end{tabular}


Continuação

Quadro I - Perfil do Município de Marília em relação ao Estado de São Paulo conforme o ano.Fonte: Fundação SEADE

\begin{tabular}{|l|c|c|c|}
\hline $\begin{array}{l}\text { Nascimentos de baixo peso } \\
\text { (menos de 2500g, \%) }\end{array}$ & 2006 & 9,35 & 9,06 \\
\hline $\begin{array}{l}\text { Leitos SUS (coeficiente por } \\
\text { mil habitantes) }\end{array}$ & 2003 & 4,30 & 1,97 \\
\hline $\begin{array}{l}\text { Índice Paulista de } \\
\text { Responsabilidade Social } \\
\text { (IPRS) - riqueza }\end{array}$ & 2004 & 41 & 52 \\
\hline $\begin{array}{l}\text { IPRS - longevidade per capita (em } \\
\text { Índice de Desenvolvimento }\end{array}$ & 2000 & 0,821 & 70,814 \\
\hline Humano Municipal (IDHM) & 2004 & 2,77 & 2,92 \\
\hline $\begin{array}{l}\text { Renda pários mínimos) } \\
\text { salárap (em reais }\end{array}$ & 2005 & $10.044,88$ & $17.977,31$ \\
\hline $\begin{array}{l}\text { PIB per capita } \\
\text { correntes) }\end{array}$ & 2005 & 0,303973 & - \\
\hline $\begin{array}{l}\text { Participação do PIB do } \\
\text { estado (\%) }\end{array}$ & & & \\
\hline
\end{tabular}

Fonte: Fundação SEADE

Marília apresenta bons índices em comparação ao estado de São Paulo. Seu grau de urbanização, índice de envelhecimento e de mães que realizaram sete consultas ou mais de pré-natal é maior do que do estado; já em relação aos índices que se interessa que diminuam, como a taxa de fecundidade, natalidade e de mães adolescentes, o município apresenta taxa menor do que do estado. Isso mostra que as ações da atenção básica podem estar se refletindo na mudança de perfil da população, já que neste ano se completa dez anos que o PACS e a ESF foram introduzidos no município.

Atualmente, a atenção básica local conta com 31 USF e 12 UBS, mostrando ainda existir um modelo de atenção à saúde misto. Desta forma, pode haver divergências nas ações realizadas pelos ACS do município; das 31 USFs, quatro se 
localizam na zona rural. $\mathrm{O}$ atendimento da população desta área é feito por uma equipe de saúde que se divide para atender duas unidades localizadas em espaço físico distinto ${ }^{36}$.

A rede municipal conta outros setores de apoio, como dois PA, uma policlínica, um banco de leite, um programa de internação e interação domiciliar (PROIID), um centro de referência de saúde do trabalhador, uma unidade de prevenção e educação em saúde (UPES), uma unidade central de assistência farmacêutica (UCAF), um núcleo de vigilância à saúde, dois centros de atenção psicossocial (CAPS), um centro de treinamento em vigilância à saúde (NEPEM), um serviço de fisioterapia, um centro de especialidades odontológicas (CEO), uma Santa Casa, um hospital de clínicas, com dois prédios, sendo um para a saúde da mulher e da criança, e outro, saúde do adulto ${ }^{36}$.

Em relação aos gastos anuais com o setor saúde do município de Marília, as despesas per capita ficam em torno de $\mathrm{R} \$ 383,00$. Os principais atendimentos básicos foram consulta em clínica médica e consultas de urgência em clínica básica. Já nas especialidades, os principais foram os atendimentos em fonoaudiologia e os de dermatologia ${ }^{36}$.

Em relação aos equipamentos sociais, Marília apresenta nove Casas do Pequeno Cidadão, atendendo 1.200 crianças e adolescentes, tirando-os das ruas; uma unidade abrigo, que tem capacidade para 22 crianças/adolescentes do sexo masculino; um centro profissionalizante - CEPROM, que oferece cursos para pessoas acima de 15 anos nas áreas de construção civil, elétrica, informática, assistente administrativo e manipulação de alimentos, atendendo 230 jovens e adultos; um centro dia Anos Dourados, onde são realizadas atividades com idosos; um centro de referência para atendimento à mulher em situação de violência; um centro de referência de atendimento ao migrante/morador de rua; três centros de referência de assistência social (CRAS), responsáveis pela oferta de serviços continuados de proteção social básica de assistência social, os quais realizam, por ano, atendimento a 1000 famílias; um centro de referência especializado de assistência social (CREAS), que orienta indivíduos que tenham seus direitos violados, como crianças, adolescentes, vítimas de violência sexual, social e física, de maus tratos e pessoas em situação de vulnerabilidade social ${ }^{36}$. 
No Mapa I abaixo, pode-se visualizar a distribuição das unidades de saúde que compõem a atenção básica do município de Marília.

Mapa I: Distribuição das Unidades da Rede de Atenção Básica do Município de Marília e seu projeto de expansão das USF. Marília - 2009.

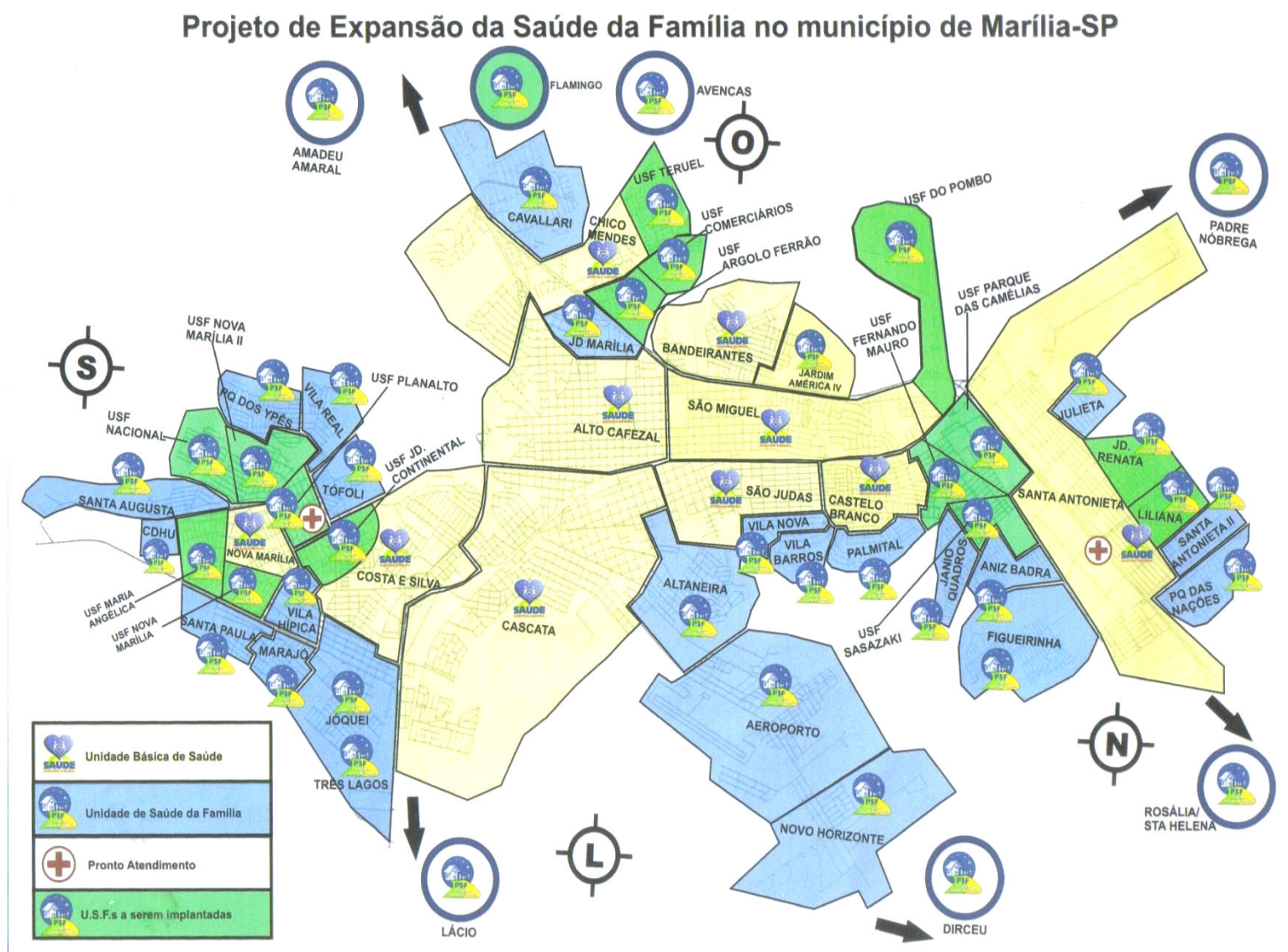

Fonte: Secretaria Municipal de Marília

Após conhecer o cenário de estudo, optou-se por trabalhar com todos os ACS do município de Marília, tanto os pertencentes às UBS como às USF, devido ao número da amostra.

\subsection{SUJEITOS DA PESQUISA}


Os sujeitos deste estudo representam uma população, entre UBS e USF, de 298 ACS. O critério de seleção utilizado foi a voluntariedade em participar da pesquisa. Dos 298 profissionais que fazem parte do quadro de ACS do município, 167 aceitaram participar.

Por existir, ainda em Marília, um modelo misto de atenção à saúde, esta pesquisa buscou entrevistar os ACS tanto inseridos nas UBS como nas USF. Na UBS, existe uma enfermeira responsável por coordenar os ACS, ou seja, uma enfermeira responsável pelo PACS. Já na USF, a enfermeira, o dentista e o médico são responsáveis pelo ACS, o que talvez possa diferenciar o tipo de atuação de cada grupo.

\subsection{COLETA DE DADOS: INSTRUMENTO E PROCEDIMENTOS}

\section{UTILIZADOS}

O instrumento utilizado para coleta de dados foi um questionário formulado por outra autora ${ }^{25}$, que se baseou nas competências propostas pelo $\mathrm{MS}^{14}$ e as codificou em frequências, a fim de facilitar a leitura dos dados para a obtenção de respostas fidedignas e objetivas, sem que haja a participação direta do pesquisador. Outra autora utilizou o mesmo instrumento na coleta de dados, em São Paulo, em 2008 .

Tal questionário estruturado, de questões fechadas (anexo I), foi aplicado a todos os ACS da rede, com o objetivo de mapear as ações realizadas por eles no município.

Para a coleta dos dados, foi feito um contato telefônico com todas as enfermeiras das UBS e USF, explicando do que se tratava a pesquisa e qual era seu objetivo. Após esse contato, foi contratada uma pessoa, que levou pessoalmente os questionários a todas as unidades de saúde e orientou-as, inclusive quanto ao prazo de entrega em 30 dias, via malote. Dos 298 questionários enviados, retornaram 167, o que representa $56 \%$ do total de ACS do municipio.

As respostas obtidas foram organizadas com a utilização do software SPSS (acrônimo de Statistical Package for the Social Sciences - pacote estatístico para as 
Ciências Sociais), e analisados com base nas frequências simples e gráficos gerados pelo programa através dos dados coletados.

Tais gráficos, que seguem ao longo deste trabalho, mostram a frequência com que cada uma das competências ${ }^{14}$ abaixo, vem sendo realizada pelos ACS:

A - integração da equipe com a população local;

B - planejamento e avaliação;

C - promoção da saúde;

$\mathrm{D}$ - prevenção e monitoramento de risco ambiental e sanitário, e

E - prevenção e monitoramento a grupos específicos e morbidades.

Nesta pesquisa, maior ênfase foi dada ao eixo de Promoção da Saúde, ou seja, a Competência C.

\subsection{CONSIDERAÇÕES ÉTICAS SOBRE A PESQUISA}

Antecedendo a coleta de dados, por se tratar de uma pesquisa que envolve seres humanos, a pesquisa foi submetida à avaliação do comitê de pesquisa da Escola de Enfermagem da Universidade de São Paulo e da Secretaria Municipal de Saúde de Marília. 


\section{RESULTADOS E DISCUSSÃO}




\section{RESULTADOS E DISCUSSÃO}

\subsection{CARACTERIZAÇÃO DEMOGRÁFICA DOS ACS DO MUNICÍPIO DE MARÍLIA}

A coleta de dados aconteceu entre abril e maio de 2009. Nesse período, o município de Marília contava com um quadro de 298 ACS, sendo que 151 (50,5\%) trabalhavam nas UBS e 147 (49,3\%) nas ESF; quadro reduzido frente ao número de unidades existentes e o exigido pela normatização do Ministério de Saúde (2006). Afinal, este órgão preconiza que cada ACS tenha sob sua responsabilidade, em média, 400 a 750 pessoas, não passando de, no máximo, 4.500 pessoas por unidade de saúde da família e Marília conta com uma população de aproximadamente 226 mil habitantes ${ }^{6}$.

Em outro trabalho ${ }^{24}$, realizado neste mesmo município, o número total de ACS era de 339 e havia menos unidades (25 USF e 13 UBS) que atualmente (31 USF e 12 UBS). Confirma-se, assim, a redução do quadro de ACS do município em $12 \%$, em apenas quatro anos. Além disso, a maioria dos ACS se encontrava trabalhando nas UBS, o que difere da situação atual. Hoje, a cobertura da ESF gira em torno de $45 \%{ }^{36}$.

Como informado anteriormente, dos 298 ACS apenas $167 \quad(56 \%)$ responderam ao questionário, e esse será o número da amostra. Desse total, 71 $(42,5 \%)$ pertenciam às UBS $(42,5 \%)$ e $96(57,4 \%)$ às USF.

A tabela, abaixo, mostra as características sociodemográficas dessa população.

Tabela 1 - Distribuição dos Agentes Comunitários de Saúde segundo os dados sociodemográficos, Marília - 2009.

\begin{tabular}{l|r|c} 
Variável & Número & Porcentagem \\
\hline Sexo & 8 & 4,8 \\
Masculino & 89 & 95,2 \\
Feminino & 159
\end{tabular}

Continua 
Continuação

Tabela 1 - Distribuição dos Agentes Comunitários de Saúde segundo os dados sociodemográficos, Marília - 2009.

\begin{tabular}{|c|c|c|}
\hline $\begin{array}{l}\text { Raça/Cor } \\
\text { Preta } \\
\text { Branca } \\
\text { Parda }\end{array}$ & $\begin{array}{r}12 \\
111 \\
44\end{array}$ & $\begin{array}{r}7,2 \\
66,5 \\
26,3\end{array}$ \\
\hline $\begin{array}{l}\text { Região de nascimento } \\
\text { Sul } \\
\text { Sudeste } \\
\text { Centro-oeste } \\
\text { Nordeste }\end{array}$ & $\begin{array}{r}15 \\
146 \\
2 \\
3\end{array}$ & $\begin{array}{r}9,0 \\
87,4 \\
1,2 \\
1,8\end{array}$ \\
\hline $\begin{array}{l}\text { Local de nascimento } \\
\text { Zona rural } \\
\text { Zona urbana }\end{array}$ & $\begin{array}{r}32 \\
134\end{array}$ & $\begin{array}{l}19,2 \\
80,2\end{array}$ \\
\hline $\begin{array}{l}\text { Estado civil } \\
\text { Solteiro } \\
\text { Unido } \\
\text { Separado } \\
\text { Viúvo } \\
\text { Não responderam } \\
\end{array}$ & $\begin{array}{r}22 \\
118 \\
22 \\
3 \\
2 \\
\end{array}$ & $\begin{array}{r}13,2 \\
70,7 \\
13,2 \\
1,8 \\
1,2 \\
\end{array}$ \\
\hline $\begin{array}{l}\text { Escolaridade } \\
\text { Ensino fundamental incompleto } \\
\text { Ensino fundamental } \\
\text { Ensino médio } \\
\text { Ensino superior } \\
\text { Não respondeu } \\
\end{array}$ & $\begin{array}{r}1 \\
3 \\
138 \\
14 \\
11 \\
\end{array}$ & $\begin{array}{r}0,6 \\
1,8 \\
82,6 \\
8,4 \\
6,6 \\
\end{array}$ \\
\hline $\begin{array}{l}\text { Tipo de moradia } \\
\text { Própria } \\
\text { Alugada } \\
\text { Cedida } \\
\text { Outros }\end{array}$ & $\begin{array}{r}109 \\
29 \\
11 \\
16\end{array}$ & $\begin{array}{r}65,3 \\
17,4 \\
6,6 \\
9,6\end{array}$ \\
\hline
\end{tabular}

Ao interpretar a tabela 1 , esta mostra, como outras pesquisas ${ }^{23,24,25,39,40}$, a prevalência de profissionais do sexo feminino trabalhando como ACS. Em Marília são 95,2\%, ou seja, 159 mulheres, com predominância da raça branca $(66,5 \%)$, seguida da parda (26,3\%). A região de nascimento referida pelos ACS é a Sudeste $(87,4 \%)$, seguida pela Sul (9\%), com menor incidência de pessoas nascidas na região Centro-Oeste (1,2\%). Do total, $80,2 \%$ nasceram na zona urbana e apenas $19,2 \%$ na zona rural. 
Em São Bernardo do Campo ${ }^{25}$, o perfil dos ACS assemelha-se ao de Marília: a maioria é da cor branca, seguida pela parda, com predomínio de nascimento na região Sudeste. Já na pesquisa ${ }^{24}$ que analisou os ACS do bairro Bela Vista, área central de São Paulo, houve predomínio da cor parda, com a mesma prevalência da região de nascimento.

Em relação ao estado civil, a predominância de ACS casados ou unidos é de $70,7 \%$. Isto se refere a qualquer tipo de união, seja ela oficializada ou não. Já no que se refere à escolaridade dos pesquisados, $82,6 \%$ completaram o ensino médio, $6,6 \%$ têm nível superior completo e apenas $0,6 \%$ tem o ensino fundamental incompleto. Em relação ao tipo de moradia, $65,3 \%$ possuem casa própria.

No trabalho realizado em São Bernardo do Campo ${ }^{25}$, quase a maioria dos respondentes eram solteiros, com ensino médio completo e moradia própria referida em $31 \%$ dos casos; no trabalho de São Paulo $^{23}$, há predomínio da união estável e também, na sua maioria, os ACS possuem o ensino médio completo e casa própria, assemelhando-se ao perfil de Marília. Outro estudo realizado em Marília ${ }^{24}$, registrou dados semelhantes ao apresentado por este trabalho, conclui-se que, em quatro anos, não houve mudanças significativas no perfil dos ACS do município de Marília, porém houve um aumento de profissionais que completaram o ensino superior, de $6,9 \%$ para $8,4 \%$.

Com relação às ocupações anteriores dos ACS, pode-se visualizar a tabela 2, abaixo.

Tabela 2 - Relação das principais profissões citadas pelos respondentes antes de ingressar na profissão de ACS, Marília - 2009.

\begin{tabular}{l|c}
\hline Profissão & \% \\
\hline Secretária/recepcionista & 14,4 \\
"Do lar" & 12,0 \\
Vendedora & 9,0 \\
Empregada doméstica & 6,6 \\
Professora & 6,0 \\
Operadora de caixa & 4,8 \\
Comerciária & 3,6 \\
Auxiliar de escrita/digitadora & 3,6 \\
Babá/cuidadora & 3,6 \\
Costureira & 3,0 \\
Outras & 26,3 \\
Não respondeu & 4,2 \\
\hline
\end{tabular}


Conforme visualizado na tabela acima, a profissão exercida anteriormente, que aparece de forma predominante entre os ACS, é a de recepcionista $(14,4 \%)$, seguida pela de "do lar" (12\%), vendedora (9\%), empregada doméstica $(6,6 \%)$, professora $(6 \%)$, operadora de caixa $(4,8 \%)$. Dos entrevistados, 4,2\% não responderam e a soma entre todas as outras profissões referidas se faz um total de $26,3 \%$. As profissões citadas, de certa forma, possuem certa relação com a profissão de ACS, já que a maioria mantém relação com o quesito comunicação e, para $12 \%$ representou a oportunidade de inserção no mercado de trabalho.

A pesquisa anterior realizada em Marília ${ }^{24}$ demonstrou que os ACS, naquele ano, possuíam, na sua maioria, formação profissional na área da saúde e educação; no trabalho de São Bernardo do $\mathrm{Campo}^{25}$, também houve um predomínio da capacitação profissional relacionada à área da saúde e a função que mais se exercia antes de ser ACS era de empregada doméstica. No trabalho de São Paulo ${ }^{23}$, a maioria dos ACS não realizou curso profissionalizante, e entre os que o fizeram, a maioria estava voltada para a área da saúde; em relação à profissão anteriormente exercida, diferentemente dos trabalhos anteriores, houve um predomínio de profissões relacionadas à área administrativa.

A tabela 3 abaixo mostra como se dava a inserção no mercado de trabalho.

Tabela 3 - Detalhamento da inserção no trabalho dos ACS do município de Marília 2009.

\begin{tabular}{l|l}
\hline Variável & Porcentagem \\
\hline Registro em Carteira antes de ser ACS & $89,2 \%$ \\
Atividade extra ao trabalho de ACS remunerada & $13,8 \%$ \\
Curso profissionalizante? & $68,2 \%$ \\
& \\
\hline
\end{tabular}

A tabela 3 mostra que o ACS, antes de exercer essa função, trabalhava em uma profissão que lhe garantia seus direitos trabalhistas, visto que $89,2 \%$ dos participantes apresentavam registro em carteira. Outro dado obtido foi que, atualmente, apenas 13,8\% realizam outra atividade remunerada além de ser ACS. Muitos dos entrevistados realizaram algum tipo de curso profissionalizante $68,2 \%$, porém, destes, só 15 (9\%) consideraram o Centro de Formação dos Trabalhadores da Saúde (CEFOR) como curso profissionalizante. Em São Bernardo dos Campo ${ }^{25}$, a porcentagem de respondentes que possuíam carteira assinada era de 74,3\% e $27 \%$ exerciam outra função remunerada. Em São $\mathrm{Paulo}^{23}, 87 \%$ de seus respondentes 
possuíam carteira assinada antes de ser ACS e apenas 6\% realizavam outra atividade remunerada.

O CEFOR foi criado por meio do Decreto $n^{\circ} 28625$, de 31 de março de 1990, com a função de aprimorar e formar trabalhadores da saúde com foco na qualificação profissional. O curso para habilitação profissional de Técnico Agente Comunitário de Saúde foi dividido em três módulos, porém no município de Marília somente a primeira etapa foi concluída ${ }^{41}$.

O principal objetivo desse curso é a formação de trabalhadores que busquem a consolidação do SUS através de ações de ensino-aprendizagem que favoreçam as dimensões técnica, ética, política e comunicativa, para melhoria da qualidade de vida da população, além da formação de profissionais que compreendam a importância do trabalho multidisciplinar, que desenvolvam ações de cuidado e proteção à saúde dos grupos sociais e coletividade no campo da Promoção da Saúde e prevenção de doenças, utilizando processos educativos em saúde, promoção social e proteção da cidadania $^{41}$.

Até o momento, para desempenhar a atividade de ACS, não se exige qualquer curso profissionalizante, apenas o ensino médio, 18 anos completos e residir na área de abrangência da unidade de saúde onde pretende atuar, o que acaba atraindo pessoas que identificam-se com as atividades que esse profissional faz, porém não têm qualquer qualificação prévia para o trabalho em saúde. O pequeno nível de exigência atrai, também, pessoas que estão, há tempo, aguardando uma oportunidade de trabalho, seja nessa ou em qualquer área.

Isto pode ser identificado nesse trabalho, já que $28,7 \%$ dos participantes relatam que enxergaram na profissão de ACS uma oportunidade de emprego, 27,5\% porque gostam da área da saúde e 17,4\% por gostarem de trabalhar com pessoas. Os trabalhos de São Bernardo do $\mathrm{Campo}^{25}$ e de São Paulo ${ }^{23}$ também se mostraram semelhantes: a maioria escolheu a profissão como uma oportunidade de trabalho. Nestes mesmos trabalhos ${ }^{25,23}$, o principal motivo de se tornar um ACS foi a falta de oportunidades no mercado de trabalho, o que não difere dos resultados das demais pesquisas citadas.

Em um artigo de revisão bibliográfica, que tinha como objetivo, sistematizar as referências que relacionavam as concepções que integram a formação com o processo de trabalho dos ACS no âmbito do PACS e ESF, os resultados apontaram 
que os respondentes relatam inexperiência em trabalhos anteriores, desconheciam o ofício no qual ingressaram e que não havia anteriormente curiosidade em saber o que era o trabalho daqueles que batiam em suas portas ${ }^{42}$.

Quando questionados se gostam de ser ACS, 97\% responderam que sim e apenas três $(1,8 \%)$ responderam que não, o que mostra que, mesmo identificando essa profissão como uma oportunidade de emprego, a maioria acabou por se identificar e gostar do que faz. Dois participantes deixaram essa questão em branco $(1,2 \%)$. Os trabalhos de São Bernardo do Campo ${ }^{25}$ e São Paulo ${ }^{23}$ confirmam esse mesmo percentual.

Com relação às variáveis idade, número de filhos, renda familiar, número de pessoas que vivem com a renda citada, tempo de moradia e tempo de trabalho no PACS/ESF, o quadro 2, abaixo, retrata estas informações.

Quadro 2 - Caracterização do ACS conforme idade, número de filhos, renda familiar, número de pessoas que vivem com a renda referida, tempo de residência no bairro e tempo de trabalho na ESF e UBS no município de Marília - 2009.

\begin{tabular}{|l|l|l|l|}
\hline Variável & Média & Valor mínimo & Valor máximo \\
\hline Idade & 38,4 & 25 & 63 \\
\hline Número de filhos & 1,7 & 0 & 6 \\
\hline Renda familiar & $\mathrm{R} \$ 1.260$ & $\mathrm{R} \$ 442$ & $\mathrm{R} \$ 3.500$ \\
\hline $\begin{array}{l}\text { Número de pessoas que vivem } \\
\text { com a renda citada }\end{array}$ & 3,5 & 1 & 7 \\
\hline $\begin{array}{l}\text { Tempo de moradia no bairro } \\
\text { (em anos) }\end{array}$ & 16,2 & 0 & 51 \\
\hline $\begin{array}{l}\text { Tempo de trabalho na ESF/UBS } \\
\text { (em anos) }\end{array}$ & 5,2 & 0 & 10 \\
\hline
\end{tabular}

Este quadro retrata um pouco da realidade destes profissionais no município de Marília: a média da renda familiar gira em torno de $\mathrm{R} \$ 1.260$ reais, sendo que 3,5 pessoas vivem com essa renda. A idade média destes ACS é de 38,4 anos, com média de natalidade de 1,7 filhos. A média de idade dos funcionários, nos trabalhos de São Bernardo ${ }^{25}$, Marília ${ }^{24}$ e São Paulo ${ }^{23}$ se assemelham à encontrada em neste estudo.

A totalidade dos ACS entrevistados reside no bairro onde trabalha. Esse é um requisito fundamental para se exercer esta função no município; o tempo médio de 
moradia no bairro é de 16,2 anos e o tempo de inserção no programa é de 5,2 anos, o que caracteriza uma população que já apresenta certa experiência na função que exerce, além de conhecer bem a área de trabalho. Afinal, com 16 anos morando em um mesmo bairro, consegue-se conhecer um pouco de sua dinâmica, das pessoas, lideranças, áreas de risco e possibilidades de parcerias.

Em outros trabalhos que investigaram esse mesmo dado, tem-se o tempo de moradia no bairro de $13,8^{24}$ a $15 \operatorname{anos}^{25,23}$. Quanto ao tempo de inserção no PACS/ESF, tal período variou de 27 meses $(2,3 \text { anos })^{24}$ a 47,7 meses $(3,9 \text { anos })^{25}$ e até de 4 a $6 \operatorname{anos}^{23}$.

Outros estudos ${ }^{8,25,23,43}$, demonstram que o predomínio das mulheres nessa profissão se difunde em todo país, e cada vez mais a mulher vem contribuindo para a renda familiar, dedicando-se, não somente aos afazeres domésticos, mas também a atividades que geram o sustento do lar. Ao se analisar que mais de $13 \%$ dos profissionais pesquisados realizam, ainda, uma atividade extra, percebe-se que há uma necessidade de complementação da renda, pois algumas famílias possuem até sete membros.

A pesquisa realizada em São Paulo (região central, bairro Bela Vista) ${ }^{23}$, 33\% dos respondentes referem uma renda de $\mathrm{R} \$ 500$ a 800 , e $47 \%$, no valor de 1.500 , sendo que $20 \%$ dos respondentes relatam que duas pessoas vivem com essa renda, e $41 \%$, três pessoas; já o trabalho de São Bernardo do Campo ${ }^{25}$ traz que a menor renda apresentada foi de 1,1 salário mínimo (em média de R\$450) e o máximo de 15 salários mínimos (R\$ 6750), tendo como média 3,2 salários (em média de R\$ 1350). O mínimo de pessoas vivendo com essa média de renda é uma pessoa; o máximo, 10, e a média, de 3,6 pessoas.

Esses dados referentes à renda familiar, comparados com o presente trabalho, mostram que a renda no município de São Bernardo do $\mathrm{Campo}^{25}$ é menor do que a apresentada em São Paulo ${ }^{23}$ e a média apresentada por Marília, porém, sendo esta uma cidade do interior do estado de São Paulo, o custo de vida é relativamente menor ao apresentado por São Paulo $^{23}$ e São Bernardo do Campo ${ }^{25}$. Ressalte-se que, esta última, embora seja também cidade do interior, faz parte da grande São Paulo e, assim, tem seu custo de vida aumentado pela influência da capital. O IPRS referente à riqueza, em 2000, de São Bernardo do $\mathrm{Campo}^{25}$, era de 68; o de Marília, em 2004, era de $41^{38}$, e o de São Paulo $^{38}$, também em 2004, era de 52. Isto revela a 
significativa contribuição econômica apresentada por São Bernardo do Campo. O dado mostra maior riqueza em São Bernardo do Campo, porém esta se mostra mal distribuída no município; um dos motivos pode se relacionar à grande concentração industrial $^{25}$.

$\mathrm{Na}$ análise dos quesitos água encanada, coleta de lixo e saneamento básico, todas as cidades pesquisadas apresentam certa semelhança nas coberturas, aproximando-se, bastante, de 100\%. Este dado pode refletir o grau de desenvolvimento apresentado por essas cidades, já que, com tais benfeitorias, muitas complicações de saúde podem ser evitadas.

\subsection{CARACTERIZAÇÃO DAS COMPETÊNCIAS DE ATUAÇÃO DO ACS, CONFORME PROPOSTO PELO MINISTÉRIO DA SAÚDE ATRAVÉS DE FREQUÊNCIAS SIMPLES}

Esta caracterização tomou por base os dados do questionário no anexo 1 referente à frequência de realização das ações conforme as competências do ACS descritas pelo Ministério da Saúde (documento- perfil de competências do Ministério ${ }^{14}$ como sendo de responsabilidade desse profissional de saúde.

5.2.1 Descrição e análise da competência A - "integração da equipe com a população local”

A competência "integração da equipe com a população local" é composta por 10 ações. Em relação à ação "participa das reuniões em equipe", 54,4\% dos entrevistados participam semanalmente, o que percentualmente corresponde ao número de ACS inseridos na ESF (57,4\%). Realmente, nas Unidades de Saúde da Família há reuniões semanais, são sempre no mesmo dia e horário e, nelas, há a participação de todos os membros, mesmo porque, neste período, a unidade fica fechada. O índice encontrado confirma a realidade. No que se refere à participação 
na reunião, 46,1\% responderam "participar expondo suas idéias", o que mostra entrosamento entre os membros das equipes.

Os gráficos abaixo descrevem as ações da competência "integração da equipe com a população local". O primeiro, assinala a frequência de realização das atividades, classificada nos seguintes itens: todos os dias, todas as semanas, todos os meses, raramente, nunca e não respondeu; e o segundo, relaciona, apenas, os que informaram executá-las diária e raramente.

Gráfico 1- Distribuição da Frequência das ações realizadas pelos ACS relacionadas à Competência A -“Integração da equipe com a população local”. Marília - 2009.

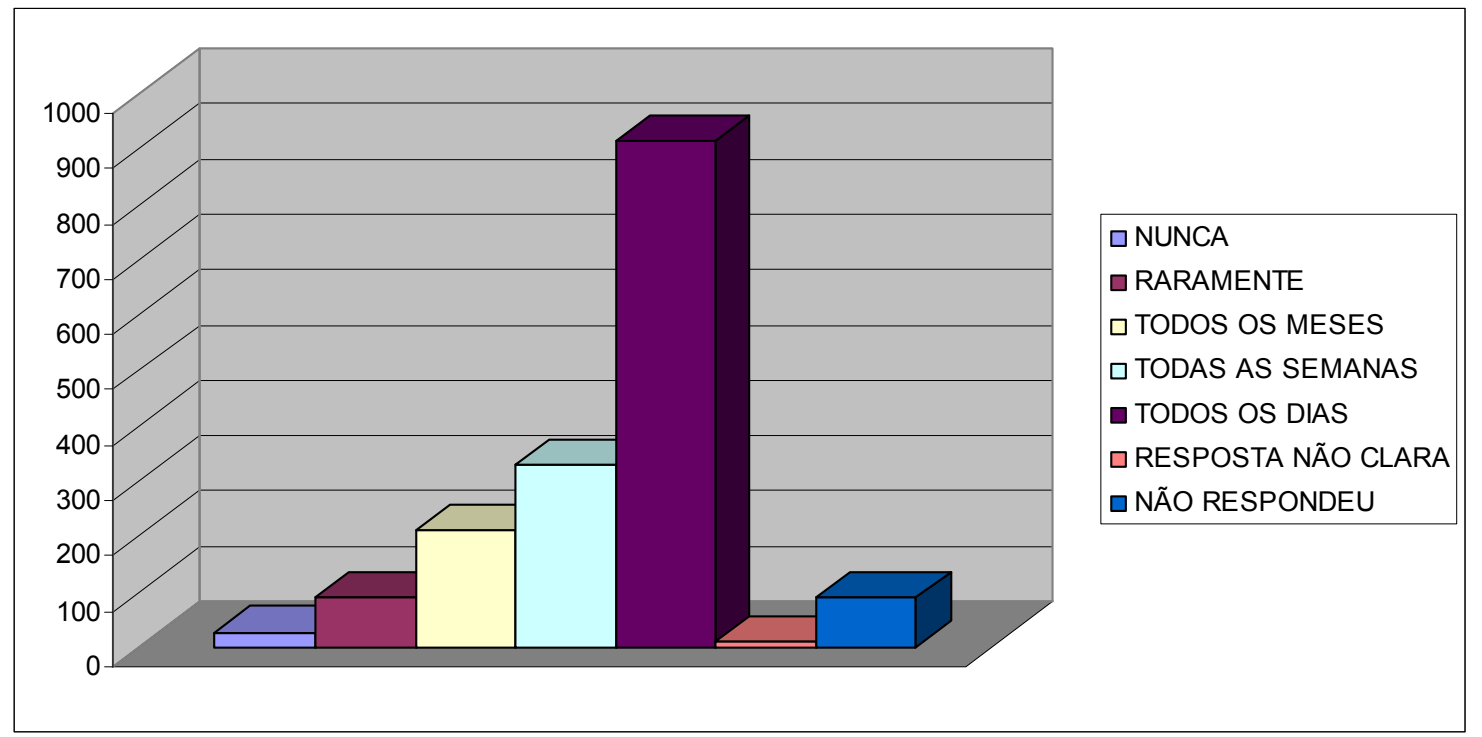

Gráfico 2 - Frequência das ações realizadas raramente e diariamente pelos ACS na competência "Integração com a equipe com a população local". Marília- 
2009

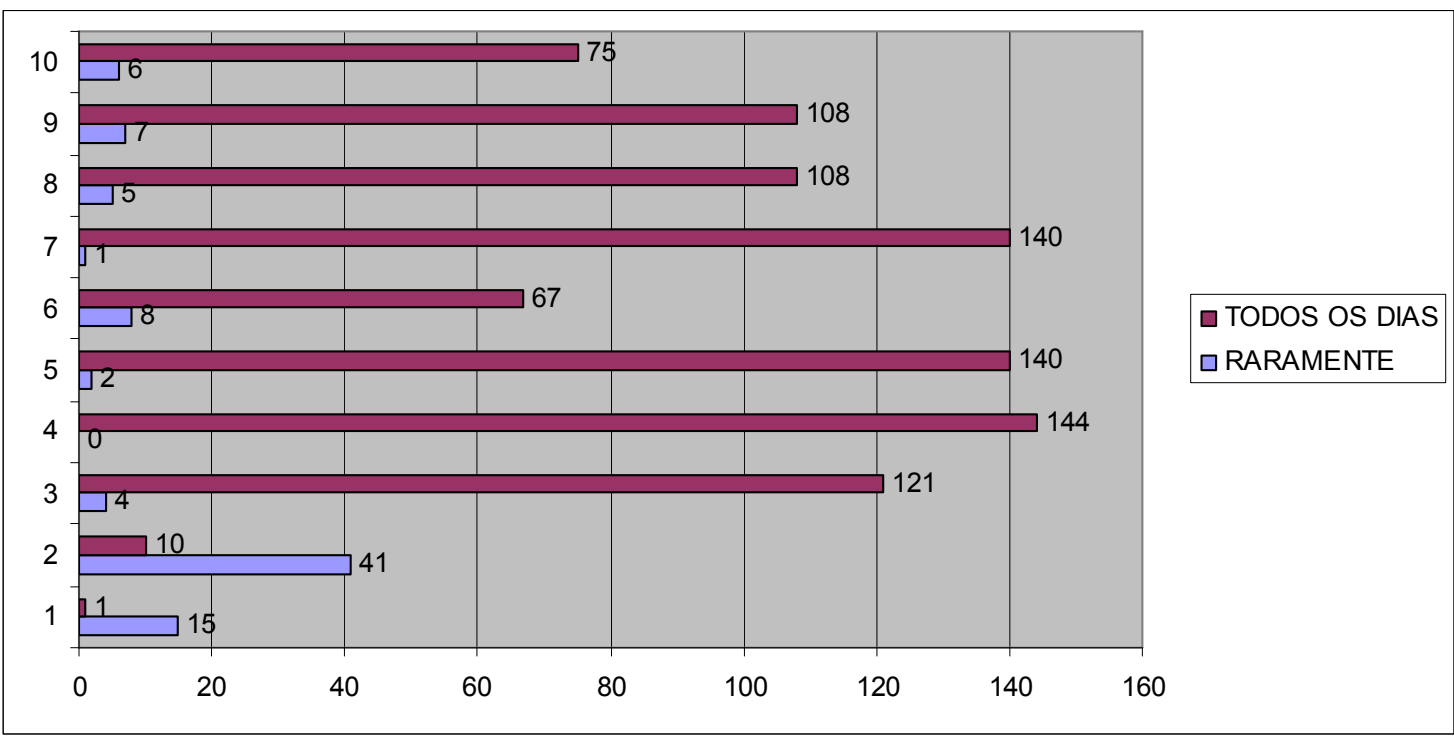

\begin{tabular}{|l|l|}
\hline A1 & Participa das reuniões em equipe \\
\hline A2 & Expõe suas opiniões nas reuniões em equipe \\
\hline A3 & Empenha-se para executar as ações propostas pela equipe \\
\hline A4 & Orienta a comunidade sobre o funcionamento da unidade, atividades e campanhas \\
\hline A5 & Orienta a comunidade quanto às ações desenvolvidas nos diversos serviços de saúde \\
\hline A6 & $\begin{array}{l}\text { Traz as necessidades da comunidade, que julga pertinente, para serem discutidas junto à equipe } \\
\text { de saúde }\end{array}$ \\
\hline A7 & Faz das visitas domiciliares a base para o desenvolvimento das suas ações como ACS \\
\hline A8 & Preenche a ficha A (cadastramento) para todas as famílias visitadas \\
\hline A9 & Preenche a fica B (acompanhamento) para todos os indivíduos dos "grupos de risco" \\
\hline A10 & Preenche a ficha C \\
\hline
\end{tabular}

Em relação à ação A3, “empenhar-se para executar as ações propostas pela equipe", 72,4\% realizam-na todos os dias; 5,9\% assinalaram em branco, e 2,4\% informaram que raramente o fazem. Essa ação faz parte do que se espera que seja realizado pelo ACS, faz parte da sua responsabilidade social; afinal, ele recebe um salário para fazer isso.

A ação A6, "traz as necessidades da comunidade que julga pertinente para serem discutidas junto à equipe de saúde", 41,9\% responderam todas as semanas; $40,1 \%$, todos os dias e 4,8\%, raramente. Esses dados mostram-se condizentes com a prática das equipes de saúde da família, pois, semanalmente, a enfermeira da unidade procura se reunir com os ACS para discussão dos casos que foram detectados nas visitas, e para o planejamento do trabalho, porém diariamente o ACS pode procurar a equipe de referência (médico, dentista e enfermeiro) para passar os casos que julga necessitarem de intervenção mais pontual e imediata. Já nas UBS, o fluxo pode ser diferenciado, pois existem duas enfermeiras (uma gerente e outra assistencial) e a equipe de ACS é maior; o contato com o médico e dentista é mais restrito, pois o 
horário de trabalho dos mesmos na unidade é reduzido e pontual. Somente os ACS e enfermeiros trabalham 8 horas/dia; os demais profissionais possuem carga horária de 3 a 4 horas/dia.

No trabalho de São Bernardo do Campo $^{25}$, 11,6\% dos ACS pesquisados levam essas demandas diariamente para serem discutidas com a equipe e 9,5\% raramente o fazem. Em comparação com a presente pesquisa, os ACS de Marília parecem ter um entrosamento melhor com a equipe de saúde.

Ao pensar nessa diferença apresentada, busca-se, em artigos e trabalhos, entender como esse ACS é visto pela comunidade e pela equipe de saúde. Tal interesse parte do pressuposto que tal profissional veio da comunidade e trouxe dela a visão de saúde ao ingressar na profissão, pois, como já citado, ainda não possuía qualificação técnica para a função de ACS. Já o interesse em entender como é visto pela equipe pode facilitar o entendimento do porque sua prática acaba se voltando para os aspectos mais biológicos do processo saúde-doença; de certa forma, ele reflete o que apreendeu com a prática diária de trabalho e influências da equipe de saúde.

Em um artigo que retrata a percepção de uma comunidade do Estado do Mato Grosso do Sul sobre o trabalho do ACS. Sua conclusão mostra que o ACS é visto como o elo entre o serviço de saúde e a comunidade, ele é referido como fonte de informações sobre o funcionamento da unidade de saúde, doenças, medicamentos ${ }^{22}$.

O mesmo retrato do ACS também pode ser observado, em um estudo realizado em um município do interior do estado de São Paulo, que partiu das relações sociais estabelecidas entre o ACS e a equipe de Saúde da Família, em situações concretas do trabalho. O ACS entende ser um educador de saúde; já a comunidade e a equipe de saúde compreendem-no como um elo entre esses dois polos, ou seja, suas funções se direcionam para atividades técnicas e assistenciais ${ }^{43}$.

Ao pensar na sua função de elo (como é visto pela equipe e comunidade) e de educador em saúde (como é visto por si próprio), pode-se entender os resultados apresentados à ação seis da competência $\mathrm{A}$, isto é, ao fato de não trazer para a equipe, a todo o momento, o que identifica na comunidade como demanda. Ao observar um problema, o ACS pode até perceber tratar-se de uma demanda para a equipe. Porém, como ele se vê como educador, apenas orienta o usuário e, embora não relate o caso, não deixa de agir como elo, pois leva para o usuário um 
conhecimento que vem do que aprendeu com a equipe e que pode evitar uma doença ou complicações. Isto vem ao encontro da forma de avaliação quantitativa do seu trabalho, que se dá através de dados de produção gerados pelo SIAB, o qual fortalece o desempenho de ações direcionadas às doenças prioritárias e não a prática reflexiva.

No item A7, "faz da visita domiciliária a base para o desenvolvimento de suas ações", $83,8 \%$ responderam realizar visitas diariamente, e apenas $0,6 \%$ informaram que raramente o fazem. Sendo assim, o ACS utiliza corretamente seu instrumento de trabalho, mas apenas metade deles discute com a equipe, ao menos semanalmente, o que foi observado, o que mostra que o ACS pode não estar refletindo sobre o seu trabalho, mas, apenas, cumprindo metas. Por outro lado, o número de agentes no município não se encontra adequado (conforme preconizado pelo Ministério da Saúde), podendo sobrecarregar o profissional, que necessita realizar um número maior de visitas para dar cobertura na área e, assim, ele não consegue parar para refletir sobre suas ações e conversar com a equipe.

No que se relaciona à ação A8, "preenche a ficha A para todas as famílias visitadas", 64,6\% dos respondentes realizam essa atividade todos os dias, e 3\%, raramente. Com este dado, consegue-se entender a falha que se encontra no SIAB, pois o número de famílias no sistema não condiz com a realidade. Afinal, ao chegarem novas famílias para a área de abrangência, imediatamente esses usuários deveriam ser cadastrados, alimentando, assim, o sistema. O SIAB também precisaria ser atualizado com relação a mudanças que ocorrem na estrutura e problemas de saúde, mas não o é. $\mathrm{O}$ mesmo ocorre em relação às fichas $\mathrm{B}$ e $\mathrm{C}$ (itens das competências A9 e A10), pois, respectivamente, apenas 64,6\% e 44,9\% referiram preenchê-las diariamente. No município de Marília, algumas equipes optaram por preencher um impresso próprio, baseado nas fichas B e C, para facilitar o trabalho. Talvez por este motivo, a frequência de preenchimento das mesmas esteja reduzida.

O estudo realizado no Mato Grosso do Sul traz também uma discussão sobre a visita domiciliária. Segundo os dados de seu estudo, $75 \%$ da população estudada referem receber a visita dos agentes no intervalo preconizado pelas normas do PACS (semanal, quinzenal e mensal), porém $25 \%$ das famílias entrevistadas disseram ser o intervalo superior a dois meses ou nunca receberam visitas. O estudo traz, como possível justificativa, a atribuição excessiva de tarefas ao ACS como: cadastros do cartão SUS, bolsa família ${ }^{22}$, número maior de famílias por ACS do que o 
preconizado (750 pessoas no máximo $)^{6}$. Em relação ao conteúdo das visitas, as famílias referem conteúdos como orientações sobre prevenção de doenças, funcionamento da unidade, uso de medicações, encaminhamento para a unidade de saúde em caso de doenças, registro das famílias, doenças e verificação do cartão vacinal $^{23}$. Percebe-se que a orientação fica em torno das doenças; não se percebe práticas relacionadas à autonomia dos indivíduos, à participação nos conselhos de saúde, aos instrumentos sociais disponíveis na comunidade, nem ações que favoreçam a promoção da Saúde, apenas prevenção de doenças. Desta forma, a preocupação fica em torno de quais conteúdos estão sendo abordados nas visitas realizadas por esses ACS, visto que a sobrecarga de trabalho não foi observada somente em Marília.

Em relação à avaliação geral do Eixo A, em comparação com o estudo de São Bernardo do $\mathrm{Campo}^{25}$ e São $\mathrm{Paulo}^{23}$, percebe-se haver semelhanças nos resultados, mesmo se tratando de municípios diferentes, com realidades distintas, pois a maioria das ações esperadas desse eixo é desempenhada entre as freqüências "todos os dias/todas as semanas/todos os meses". Isso confirma o achado de Peres $(2006)^{25}$, que traz que o ACS se percebe como interlocutor entre a unidade de saúde e a comunidade.

\subsubsection{Descrição e análise da competência $B$ - "planejamento e avaliação".}

A competência "Planejamento e Avaliação" é composta por 13 ações. Dentre elas, a de "estimular a população a participar de conselhos locais de saúde e/ou conferências municipais" (B1) é realizada por apenas 33,5\% dos ACS todos os dias, e $26,3 \%$, raramente a fazem, fato esse que justifica o que se observa, ou seja, a pouca adesão e envolvimento da população nos conselhos municipais, reuniões de associação de moradores e comunidade. Em contrapartida, 58\% dos ACS que responderam ao questionário, informam que "incentiva $(m)$ diariamente a população a participar de atividades de sua própria comunidade" (B2). 
No município de Marília, já houve algumas conferências de saúde, mas a participação foi pequena, tanto da população, como dos trabalhadores da saúde e de outros setores da Prefeitura. Este espaço se apresenta como uma das formas da população expor e discutir as necessidades apresentadas por suas comunidades, porém não é utilizado. Rothman $(2001)^{33}$ acredita ser, através da teoria de desenvolvimento local, uma forma de mobilização da comunidade para resolução de seus problemas. Algo aproximado disso poderiam ser as conferências de saúde.

$\mathrm{Na}$ análise da ação $\mathrm{B} 3$, "ao identificar riscos sociais, faz a análise da situação", 46,7\% dos respondentes realizam essa atividade diariamente, e 4,1\%, nunca. Pode-se entender que apenas metade dos respondentes está refletindo frente às situações encontradas no dia a dia de trabalho. $\mathrm{Na}$ ação B5, "identifica riscos ambientais em sua área de atuação e faz a análise da situação", os índices dos que informaram executar tal ação diariamente e dos que nunca $o$ fazem são, respectivamente, $48,5 \%$ e 3,5\%; menos da metade dos respondentes. As frequências acima citadas podem ser confirmadas pelo percentual dos que realizam diariamente as ações B6 - “examina criticamente os dados obtidos pelo cadastramento": 46,7\% — e B7 — "realiza ações com base no levantamento sobre saúde da população": $36,5 \%$.

Como geralmente se tem a implantação de uma equipe de saúde da família em áreas de risco, sejam eles ambientais ou sociais, quando o ACS, ao se deparar com tais riscos, não os analisa de forma critica, tal fato pode denotar que ele talvez não saiba o porquê de realizar as ações acima ou talvez não entenda o que esse dado pode mostrar para se planejar ações em seu território. O objetivo final é melhorar a qualidade de vida dessa comunidade, e não apenas identificar problemas, mas, sim, pensar, junto à comunidade, uma solução para os problemas detectados.

Talvez pelo fato do foco de atuação desse profissional estar centrado apenas no modelo biomédico e na cura das doenças, fique mais difícil o ACS entender o quanto o meio pode interferir na qualidade de vida das comunidades e no adoecimento destes. A pesquisa realizada no interior de São Paulo ${ }^{43}$, também constatou: a saúde parece estar dissociada de outros setores, não se misturando com problemas de outras áreas. A visão que os ACS entrevistados apresentam sobre o processo saúde-doença é desarticulada de outras dimensões sociais, e isso pode 
derivar dos referenciais nos quais esses profissionais se espelham, entre eles o da própria equipe de saúde e do modelo biológico predominante.

Os gráficos abaixo representam as respostas dos ACS em relação a essa competência:

Gráfico 3 - Distribuição da Frequência das ações realizadas pelos ACS, relacionadas à competência B - Planejamento e Avaliação. Marília - 2009

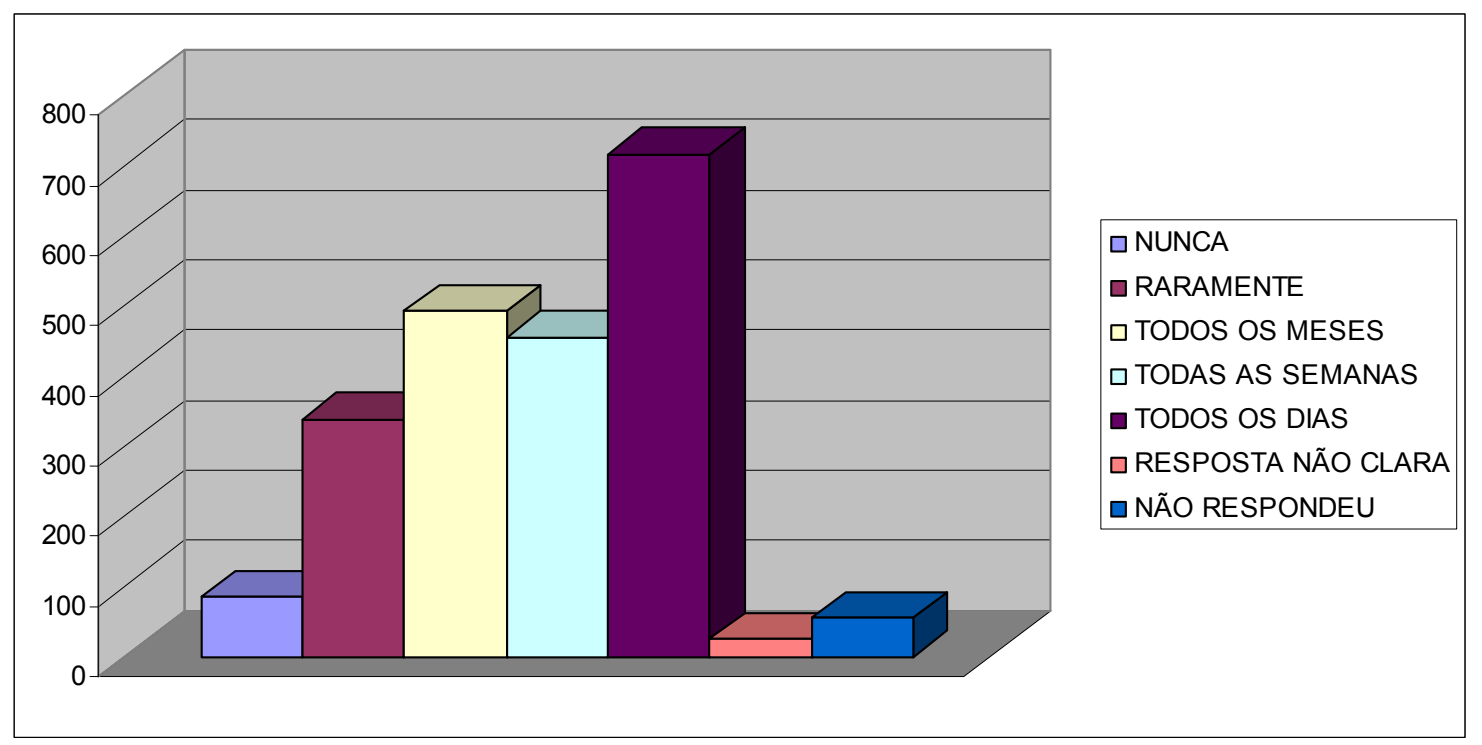

Gráfico 4 - Freqüência das ações realizadas raramente e diariamente pelos ACS na competência Planejamento e avaliação. Marília - 2009.

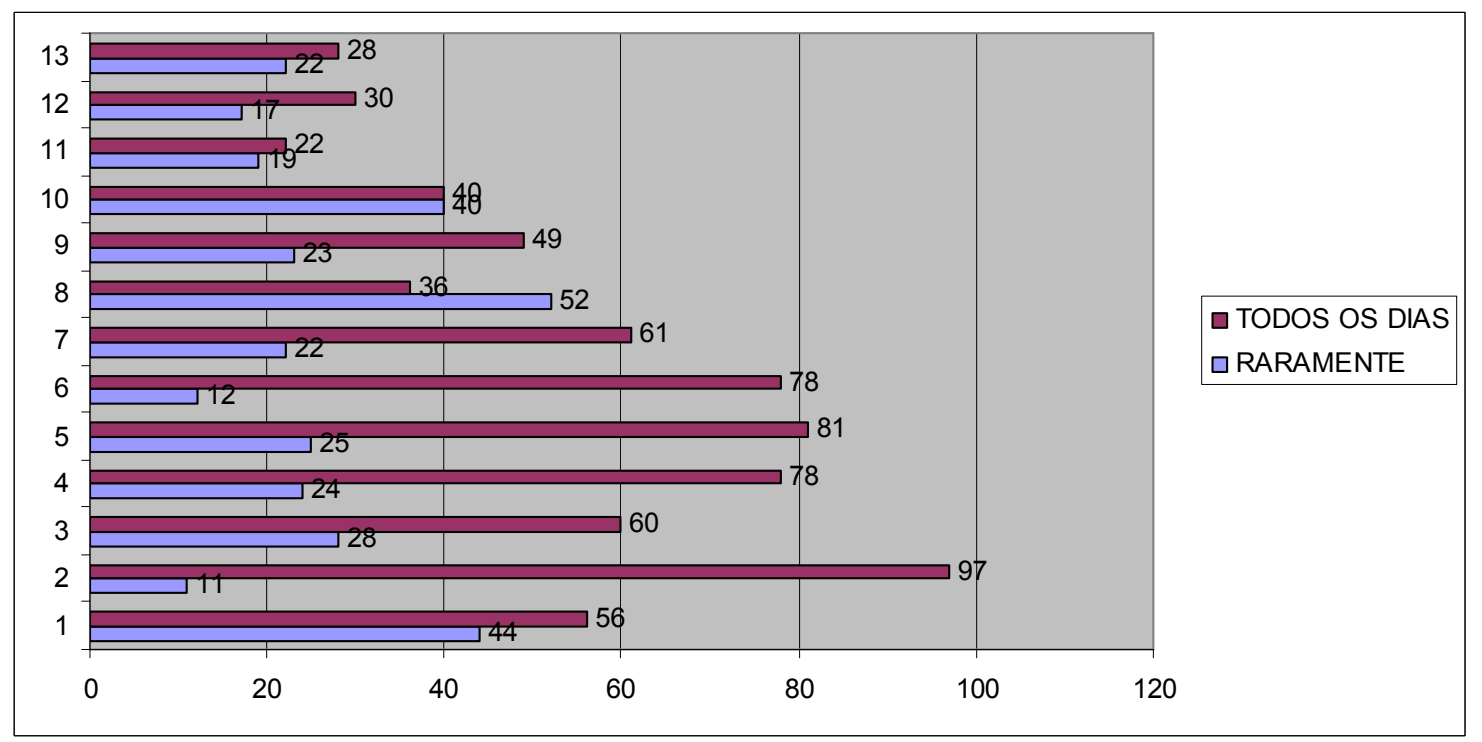




\begin{tabular}{|l|l|}
\hline B1 & Estimula a população a participar de conselhos locais de saúde e/ou conferências municipais de saúde \\
\hline B2 & Incentiva a população a participar de atividades de sua própria comunidade \\
\hline B3 & $\begin{array}{l}\text { Informa ao programa (PACS/ESF) sobre os recursos do território de sua microárea de atuação (creches, } \\
\text { associações, escolas) }\end{array}$ \\
\hline B4 & $\begin{array}{l}\text { Ao identificar riscos sociais (tráfico de drogas, violência doméstica, etc) em sua microárea de atuação, } \\
\text { faz a análise da situação }\end{array}$ \\
\hline B5 & $\begin{array}{l}\text { Ao identificar riscos ambientais (esgoto, grandes avenidas, etc) em sua microárea de atuação, faz a } \\
\text { análise da situação }\end{array}$ \\
\hline B6 & Examina criticamente os dados obtidos pelo cadastramento \\
\hline B7 & Realiza ações com base no levantamento sobre a saúde da população \\
\hline B8 & Informa à comunidade os resultados obtidos no levantamento sobre a saúde da população \\
\hline B9 & $\begin{array}{l}\text { Estabelece ações para resolução dos problemas de saúde da sua microárea de atuação, segundo critérios } \\
\text { estabelecidos pela equipe de saúde }\end{array}$ \\
\hline B10 & $\begin{array}{l}\text { Estabelece ações para resolução dos problemas de saúde de sua microárea de atuação, segundo critérios } \\
\text { estabelecidos pela população local. }\end{array}$ \\
\hline B11 & Elabora junto a sua equipe o plano de ação para atuar na comunidade \\
\hline B12 & Avalia os planos de ação desenvolvidos junto à equipe de saúde \\
\hline B13 & Reprograma os planos de ação junto à equipe de saúde \\
\hline
\end{tabular}

Ao considerar que a reunião de equipe e com a enfermeira se dá semanalmente, o que se espera é que o ACS planeje suas ações para resolução dos problemas de sua microárea nesta mesma frequência, mas, ao se analisar os dados da ação B9 "estabelece ações para resolução dos problemas de saúde de sua microárea de atuação conforme critérios estabelecidos pela equipe de saúde", observa-se que essa ação é desempenhada diariamente por 29,3\%; semanalmente, por $31,7 \%$; e raramente, por $13,8 \%$ dos respondentes. São frequências baixas, dado que diariamente o ACS se depara com problemas em suas visitas, porém não se articula para resolvê-los. Mais uma vez percebe-se que o ACS acaba apenas cumprindo metas, não refletindo sobre seu trabalho. No dia a dia de trabalho na unidade de saúde, o que vemos são, cada vez mais, atendimentos em que o usuário procura o serviço para resolução de problemas pontuais, e não para acompanhamento de sua saúde. Mais uma vez certifica-se a visão biologicista da equipe de saúde e usuários, em detrimento da promoção da saúde.

Essa questão da demanda espontânea que procura a unidade de saúde, pode ser decorrente do ACS não planejar e nem discutir, com a equipe, ações para resolução dos problemas encontrados, fragilizando o trabalho em equipe. Esse fato foi também levantado em um artigo, que discute a inserção do ACS na ESF, na perspectiva da Promoção da Saúde, e traz, como resultado de sua pesquisa, a discussão da doença como modalidade de organização do trabalho, evidenciada nas contradições dos discursos e ações dos ACS. Neles, há o reconhecimento da importância da vigilância à saúde, principalmente no que refere às ações, que deveriam ser de promoção à saúde, porém ainda estão muito voltadas para a doença, 
o que entra em contradição com o papel que é atribuído ao ACS. Por outro lado, torna-se um desafio para as equipes de saúde manter-se em constante capacitação em relação às particularidades do contexto social, político, cultural e econômico da sua microárea. Ao se pensar na lógica da prevenção de agravos e promoção da saúde, consequentemente deve-se pensar na construção social de um novo sistema de saúde, em que o trabalho do ACS tenha relação de complementaridade a dos outros profissionais da equipe de saúde. Até o momento, não há evidências de que a ESF seja suficiente para reorientar as práticas sanitárias atuais; o que poderia contribuir para isso seria a vontade política e a integração de diversas áreas do governo com olhar interssetorial para entendimento da promoção da saúde ${ }^{44}$.

\subsubsection{Descrição e análise da competência $C$ - "promoção da} saúde"

A competência "Promoção da Saúde" é composta por 16 ações e se constitui no foco principal desta pesquisa, pois o objetivo geral dela é analisar a potencialidade dos ACS na efetivação da Promoção da Saúde no município de Marília. Assim sendo, deve-se conhecer como estão sendo desempenhadas as ações de Promoção da Saúde pelos ACS que atuam tanto nas UBS, quanto nas USF do município. Por essa razão, as ações realizadas nessa competência serão analisadas utilizando-se o modelo proposto por Nutbeam $(2004)^{35}$, que se baseia nas dimensões de organização comunitária e construção de capacidade para avaliar a Promoção da Saúde (figura 1, pag. 54 apresentada no quadro teórico).

Os gráficos abaixo expressam como as ações que compõem a competência em tela estão sendo desempenhadas, e a frequência com que as respostas "diariamente" e "raramente" acontecem: 
Gráfico 5 - Distribuição da Frequência das ações realizadas pelos ACS relacionadas à competência C - "Promoção da Saúde". Marília - 2009.

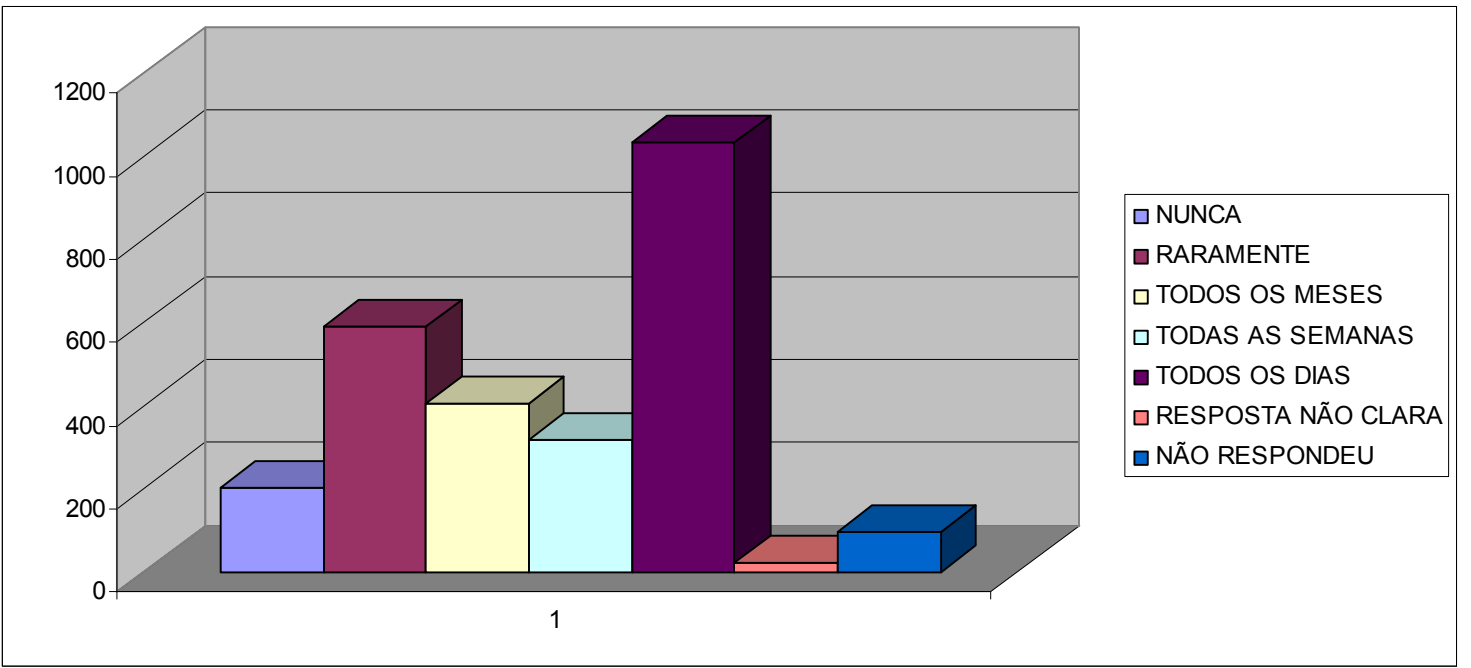

Gráfico 6- Frequência das ações realizadas raramente e diariamente pelos ACS na competência "Promoção da Saúde". Marília - 2009.

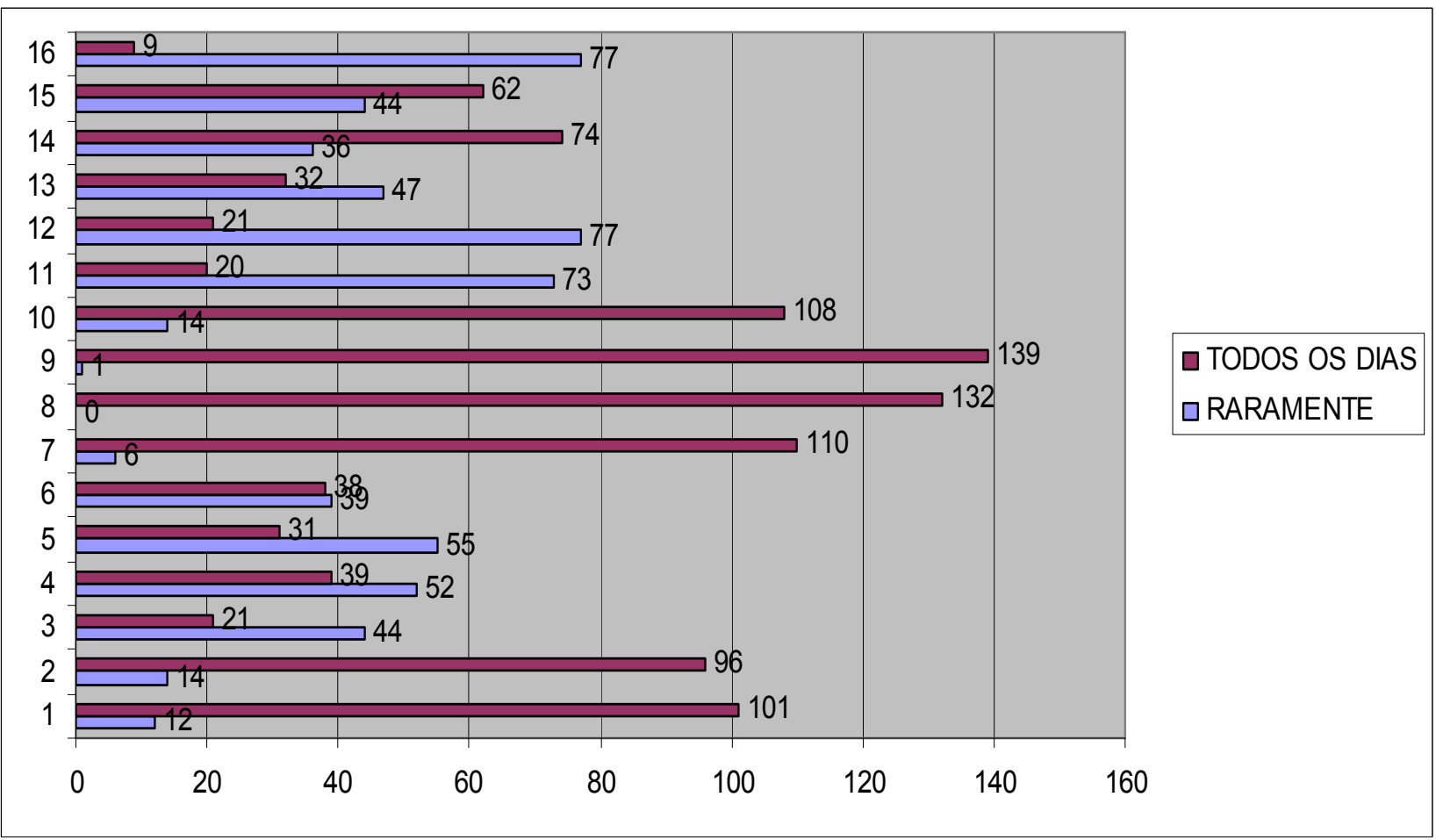

\begin{tabular}{|l|l|}
\hline C1 & Identifica a relação entre problemas de saúde e condições de vida \\
\hline C2 & Identifica exemplos positivos que promovem a saúde na comunidade \\
\hline C3 & $\begin{array}{l}\text { Realiza atividades educativas para a comunidade (palestras, campanhas, mutirões, etc) juntamente com o } \\
\text { enfermeiro }\end{array}$ \\
\hline
\end{tabular}




\begin{tabular}{|l|l|}
\hline C4 & Realiza atividades educativas com os outros ACS \\
\hline C5 & Realiza atividades educativas para a comunidade sozinho \\
\hline C6 & Utiliza recursos de informação e comunicação (faixas, panfletos, etc) adequados à realidade local \\
\hline C7 & Estimula os indivíduos e a comunidade a refletirem sobre as suas condições de saúde e doença \\
\hline C8 & Orienta indivíduos quanto ao autocuidado \\
\hline C9 & $\begin{array}{l}\text { Orienta a população quanto a medidas de proteção à saúde (alimentação, higiene pessoal, limpeza, } \\
\text { acondiciomento e destino do lixo, cuidados com a água e dejetos, outras) }\end{array}$ \\
\hline C10 & Orienta indivíduos e família quanto a medidas de prevenção de acidentes domésticos \\
\hline C11 & Propõe ações que utilizem as diversas secretarias existentes no município \\
\hline C12 & Executa ações que atua em parceria com outras secretarias no município \\
\hline C13 & Estabelece parcerias com creches, asilos, escolas, comerciantes, grupos sociais e outros \\
\hline C14 & $\begin{array}{l}\text { Orienta família e/ou portador de necessidades especiais quanto às medidas facilitadoras para a sua máxima } \\
\text { inclusão social }\end{array}$ \\
\hline C15 & Apoia ações sociais de alfabetização de crianças, adolescentes, jovens e adultos \\
\hline C16 & Participa de reuniões do Conselho Local de Saúde ou de outros conselhos locais \\
\hline
\end{tabular}

Ao avaliar os gráficos da competência $\mathrm{C}$, percebe-se haver um equilíbrio das ações realizadas nas frequências "diariamente" e "raramente". O mesmo foi observado em São Bernardo do Campo ${ }^{25}$. Na análise das competências A "Integração da equipe com a população local", B - "Planejamento e Avaliação", D "Prevenção e Monitoramento de Risco Ambiental Sanitário" e E - "Prevenção e Monitoramento a Grupos Específicos e Morbidade", houve a prevalência das ações realizadas diariamente. Isso é um bom sinal, pois, de certa forma, como o ACS sai diariamente para realizar visitas nos domicílios, espera-se que diariamente ele identifique e realize ações descritas pelo MS. Em comparação com o trabalho de São Bernardo do Campo ${ }^{25}$, os dados foram um pouco alterados, pois, houve prevalência da frequência "diariamente" apenas nas competências A, D e E. No trabalho realizado em São Paulo ${ }^{23}$ prevaleceram ações na frequência "mensalmente". Outro fato observado é a polaridade entre diariamente/semanalmente e raramente/nunca, o que pode refletir diferentes condutas nas equipes de saúde; no estudo realizado em São Bernardo do Campo ${ }^{25}$, isso também foi observado.

No que se refere à "identificação da relação entre problemas de saúde e condições de vida" $(\mathrm{C} 1), 60,5 \%$ dos respondentes afirmam realizá-la diariamente, e $7,2 \%$, raramente. Uma análise provisória parece mostrar que o ACS, a todo o momento, identifica os problemas da sua microárea, mas não os leva à equipe. Disso, pode-se, talvez, concluir que ele ainda não reflete sobre seu papel ou, pior ainda, talvez nem compreenda sua maior definição: "elo entre equipe de saúde e comunidade", ou talvez seja que a equipe de saúde não o ouça, não dê espaço para o ACS falar. 
Ao analisar estas ações, utilizando o modelo de dimensão baseado na organização comunitária e na capacidade de construção ${ }^{33}$, percebe-se que estas ficam voltadas para os problemas da comunidade identificados pelo eixo dos representantes do serviço de saúde (C1). Isto está um pouco distante do que seria o ideal para fortalecer as comunidades, pois as ações deveriam partir da comunidade em busca de seu próprio fortalecimento, para assim haver a resolução de suas necessidades.

Em um artigo, que teve como propósito a construção de um Programa de Educação para capacitar os ACS de Sorocaba, foi possível constatar que, através da capacitação, o ACS pode modificar sua tendência para a dimensão teórica. O estudo mostrou a necessidade de aprendizagem do grupo de ACS, no que se refere a exercer seu papel de líder na comunidade, participação comunitária e construção de parcerias junto da comunidade para melhoria da qualidade de vida ${ }^{17}$.

Os autores tomaram como base as competências propostas pelo Ministério da Saúde (mesma fonte utilizada nesta pesquisa) ${ }^{14}$ para identificar a atuação do ACS. Estavam presentes nos discursos dos entrevistados apenas as ações de "identificação de situações de risco", "encaminhamento de doentes para a unidade de saúde" e a “orientação para a promoção e proteção da saúde". Já no que se refere a "ações de interssetorialidade" e "mobilização da comunidade para a conquista de ambientes e condições favoráveis à saúde", elas não foram citadas, e nem observado o perfil de liderança. Isso reflete o porquê de seus discursos não apresentarem a luta para modificar determinantes de saúde, sendo o foco maior de atuação direcionado para ações preventivas de caráter individual, com ênfase na higiene. Afinal, a teoria presente nos discursos é a do modelo biológico e problemas como miséria, desemprego, falta de higiene e fome não são de "cura" imediata ${ }^{17}$.

Pode-se perceber que a atuação desses ACS resume-se a repassar conhecimento, sem a preocupação de promover qualquer transformação na comunidade. Assim, os autores apontam para necessidade de construção de um programa de educação que amplie a visão do processo saúde-doença. Este, após aplicado, gerou mudanças significativas, pois estimulou um trabalho participativo, reflexivo e transformador nos ACS de Sorocaba ${ }^{17}$.

Já o livro, que propõe um guia prático de teorias de promoção da Saúde, destaca-se que, a estratégia principal para se promover a saúde, seria o trabalho com comunidades locais ou grupos de interesses como indígenas, homossexuais, 
adolescentes, e não através do recorte por patologias, como é feito atualmente, pois essa ótica reforça ainda mais o modelo biológico. Este autor sugere a organização comunitária como forma de identificar os principais problemas de uma comunidade e, assim, mobilizar recursos para se alcançar um objetivo planejado por todos. $\mathrm{O}$ levantamento do problema deve partir da comunidade, junto com a equipe de saúde, e não apenas dos dados epidemiológicos avaliados pelos serviços de saúde. A partir desse levantamento, diz o autor, é possível tomar como base as diferentes teorias presentes em seu livro, pois possuem como objetivo a Promoção da Saúde com o intuito do fortalecimento das comunidades, para assim gerar mudanças sustentáveis ${ }^{33}$.

Já referente à "identificação de exemplos positivos que promovem a saúde na comunidade" (C2), 57,5\% realizam-na diariamente, e 8,4\%, raramente. Mais da metade dos respondentes entende que não cabe apenas à unidade de saúde a promoção da saúde. Essa ação citada acima se classifica no quadro (pag 44 quadro teórico $)^{33}$, como presente no eixo das ações voltadas para problemas partindo do serviço de saúde, e o que se espera é que isso parta da comunidade também.

Em relação à ação $\mathrm{C} 3$, "realiza atividades educativas para a comunidade junto do enfermeiro", há um equilíbrio entre as frequências "todas as semanas" (22,2\%), "todos os meses" $(28,1 \%)$, e "raramente" $(26,3 \%)$, o que pode refletir que não há um padrão único para realização dessas atividades, podendo ser conforme a necessidade da comunidade assistida. Todavia, a soma das frequências "toda semana" e "todos os meses" reflete um montante satisfatório (50,3\%). Essa ação se classifica como direcionada para o fortalecimento da comunidade, partindo de pessoas qualificadas para isso $^{33}$

Quando se analisa a ação C4, "realiza atividades educativas com outros ACS", 23,4\% fazem-na diariamente; $22,2 \%$, semanalmente, e 31,1\%, raramente. Em relação à C5: "atividades educativas sozinho para a comunidade", 18,6\% realizam-na diariamente; $18,6 \%$, todas as semanas, e $32,9 \%$, raramente. O que se pode perceber é que, sem a presença de alguém que possa auxiliá-lo no momento dessa atividade, a frequência da realização diminui. Talvez o ACS não se sinta preparado para isso, afinal, seu curso profissionalizante (CEFOR) ainda não foi concluído no município, e a própria equipe não capacita o ACS para a educação em saúde para grupos, porque também ela se encontra com uma visão biologicista do processo saúde-doença, não 
se importando com esses tipos de atividade e seus benefícios. O recorte dos grupos gira sempre em torno do que o Ministério da Saúde define como prioritário, ou seja, o recorte por patologias e não por grupos afins, como poderia ser. Então, essa conjunção de fatores dificulta a realização de ações de Educação em Saúde. Entretanto, como ACS recebeu subsídios para discutir formas de aumento da renda familiar, ele estimula o grupo nesse sentido, mostrando, por exemplo, quais parceiros buscar na sociedade para que isso aconteça. É uma outra visão de grupo, em que a base se encontra no fortalecimento das comunidades.

Este resultado difere do trabalho realizado em São Paulo ${ }^{23}$, que apresentou que, sozinho, o ACS realiza mais atividades educativas com a comunidade. No trabalho realizado em São Bernardo do Campo ${ }^{25}$, todas as ações que se relacionavam com atividades educativas, fossem elas com enfermeiro, sozinho ou com outro ACS, houve predominância das respostas na frequência "raramente". Pode-se observar que, mesmo o ACS sendo orientado por uma lista de competências padronizadas no país, ele não consegue realizar o que é esperado para sua função, o que fortalece a conclusão de que não basta atribuir-lhe tarefas; é preciso construir, junto dele, a importância em se trabalhar baseado na organização e construção comunitária para a Promoção da Saúde. É preciso estar alerta para isso ${ }^{33}$.

Não se pode esquecer que as ações de educação em saúde devem ser realizadas conforme a necessidade das diferentes comunidades, de maneira não prescritiva, estimulando o autoconhecimento, buscando criar consciência crítica, favorecendo o coletivo e estimulando a autonomia dos sujeitos ${ }^{45}$ e o ACS parece não estar muito preparado para essa prática educativa mais autônoma e de empowerment. Segundo as teorias de mudanças comunitárias ${ }^{33}$, levar a comunidade a refletir sobre quais são seus problemas de saúde e sobre formas de superá-los, através de ações conjuntas com profissionais de saúde, é uma forma de se realizar programas efetivos de promoção da saúde. Se o próprio ACS - que é um morador da comunidade e teoricamente mais "empoderado"- tem dificuldades em conduzir discussões desse tipo, torna-se óbvia a dificuldade em se desenvolver ações efetivas de promoção da saúde. Talvez esse devesse ser um trabalho dos médicos e enfermeiros junto aos ACS.

Diariamente, o ACS "estimula os indivíduos e comunidade a refletir sobre suas condições de saúde e doença" (C7): (65,3\%); "orienta o autocuidado" (C8): 
79\%, e "orienta medidas de proteção à saúde diariamente" (C9): 83,2\%. Quando se trata de algo mais diretamente relacionado à saúde-doença (biológico), o ACS, em sua maioria, executa tais tarefas muito bem. Porém, ao mesmo tempo, ele não entende que também promove a saúde quando, por exemplo, incentiva um indivíduo a participar do conselho de saúde ou de atividades na comunidade, principalmente porque, com isso, existe a possibilidade de se intervir sobre os determinantes do processo saúde-doença. Pode-se perceber isso mais claramente no que se refere às ações que contemplam a interssetorialidade, pois $43,7 \%$ raramente propõem "ações que utilizem as diversas secretarias existentes no município" (C11), e 46,1\% raramente executam "ações que atuam em parceria com outras secretarias" (C12).

O ACS consegue, apenas, estabelecer parcerias com algo que se encontra mais próximo de seu ambiente de trabalho e vivência, pois $21 \%$ conseguem toda semana "estabelecer parceria com creches, asilos, escolas, comerciantes e grupos sociais" (C13); 19,2\% referem fazer isso diariamente, e 17,4\%, todos os meses. Ainda se tem a impressão que a Secretaria de Saúde e Prefeitura são entidades muito distantes dos trabalhadores e usuários, mas já é um bom resultado se articular com a comunidade em que se vive. Nos estudos de São Bernardo do Campo ${ }^{25}$ e São $\mathrm{Paulo}^{23}$, os ACS não realizam qualquer parceria com secretarias e meios sociais da área de abrangência, o que difere deste trabalho em relação ao último item.

A dificuldade de articulação, principalmente com órgãos locais, se confirma ao ver que $46,1 \%$ dos respondentes raramente participam "de reuniões do conselho local de saúde ou outros conselhos locais" (C16), e 23,4\% nunca participam. Essas reuniões acontecem mensalmente na Secretaria de Saúde e são abertas ao público. Também mensalmente acontece, nas unidades de saúde da família, a reunião de comunidade, em horários definidos pela mesma (manhã, tarde ou noite). A participação da comunidade e equipe é pequena, embora, se a mesma for realizada fora do horário de trabalho, são computadas horas (banco de horas) para os funcionários que participam.

O ACS, de certa forma, consegue identificar a importância de parcerias, pois $44,3 \%$ orientam "família e/ou portador de necessidades especiais quanto a medidas facilitadoras para sua inclusão social" (C14) diariamente, e 19,8\%, mensalmente. No que refere a "apoia ações sociais de alfabetização de crianças, jovens e adultos" (C15) $37,1 \%$ realizam essa atividade diariamente. Esses dados corroboram com o 
trabalho realizado em São Paulo ${ }^{23}$. Em outro estudo realizado em São Paulo, que discutiu a concepção dos ACS em relação à Promoção da Saúde, também foi constatado a interssetorialidade como sendo um enorme desafio para a prática do ACS na perspectiva da Promoção da Saúde ${ }^{46}$.

A análise desta competência, Promoção da Saúde, pelo modelo proposto pelo livro que traz um guia pratica de teorias de Promoção da $S_{a u ́ d e}{ }^{33}$, demonstrou que as respostas à maioria das ações encontram-se no eixo direcionado para os problemas da comunidade, com o apoio de pessoas qualificadas para execução, ou seja, pelo serviço de saúde. Algumas ações, porém, já se encontram mais próximas do eixo comunidade e fortalecimento. Como exemplos, temos as ações C13, C14, C15 e C16, que são ações que buscam parcerias na comunidade, estímulo à inserção social de pessoas portadoras de necessidades especiais, apoio a ações de alfabetização e participação das reuniões do conselho local de saúde.

5.2.4 Descrição e análise da competência D - "prevenção e monitoramento de risco ambiental e sanitário".

A competência "Prevenção e Monitoramento de Risco Ambiental e Sanitário", é composta por cinco ações, através das quais se espera que o ACS identifique os problemas, informe a equipe e oriente os usuários. Conforme já observado no outros eixos, há a prevalência das ações realizadas diariamente, com um número relativamente menor dos que informaram que nunca ou raramente as realizam, fato também observado no trabalho em São Bernardo do Campo ${ }^{25}$.

Gráfico 7 - Distribuição da Frequência das ações realizadas pelos ACS relacionadas à competência D - Prevenção e monitoramento de risco ambiental e sanitário. 
Marília-2009.

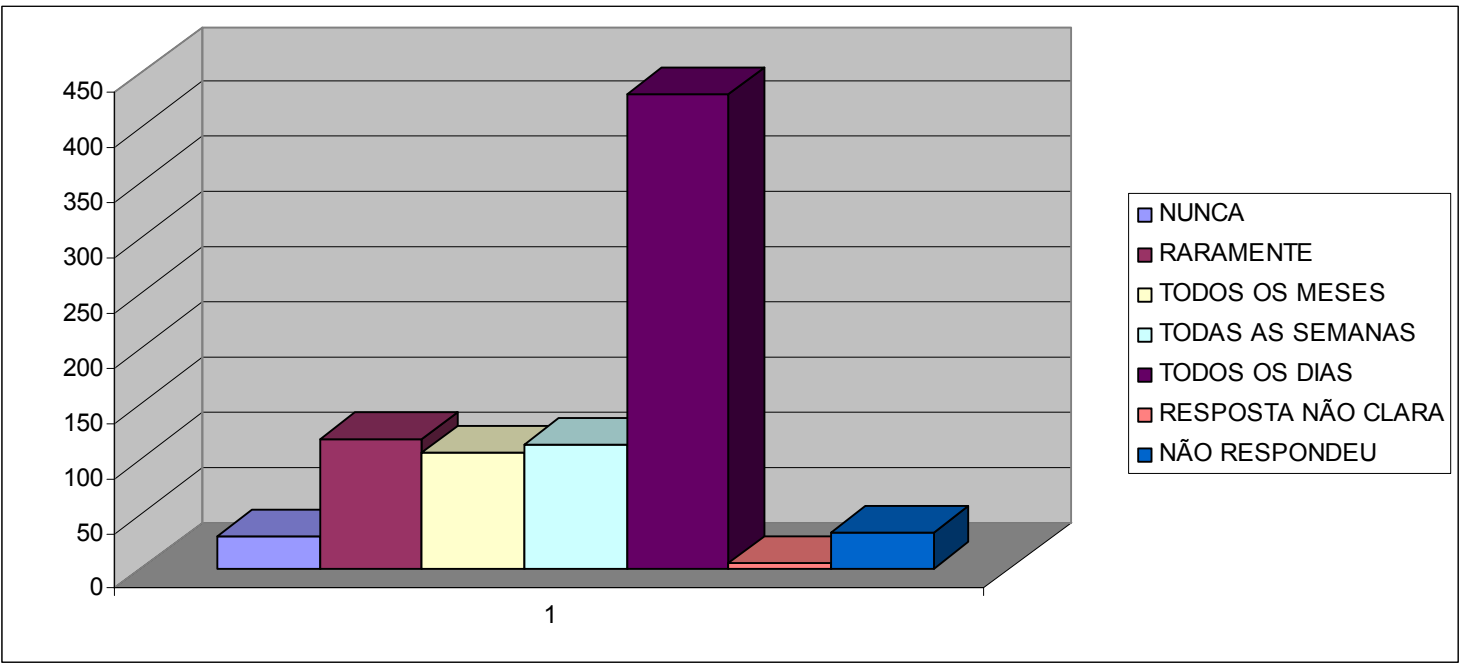

Gráfico 8- Frequência das ações realizadas raramente e diariamente pelos ACS na competência D - Prevenção e monitoramento de risco ambiental e sanitário. Marília-2009

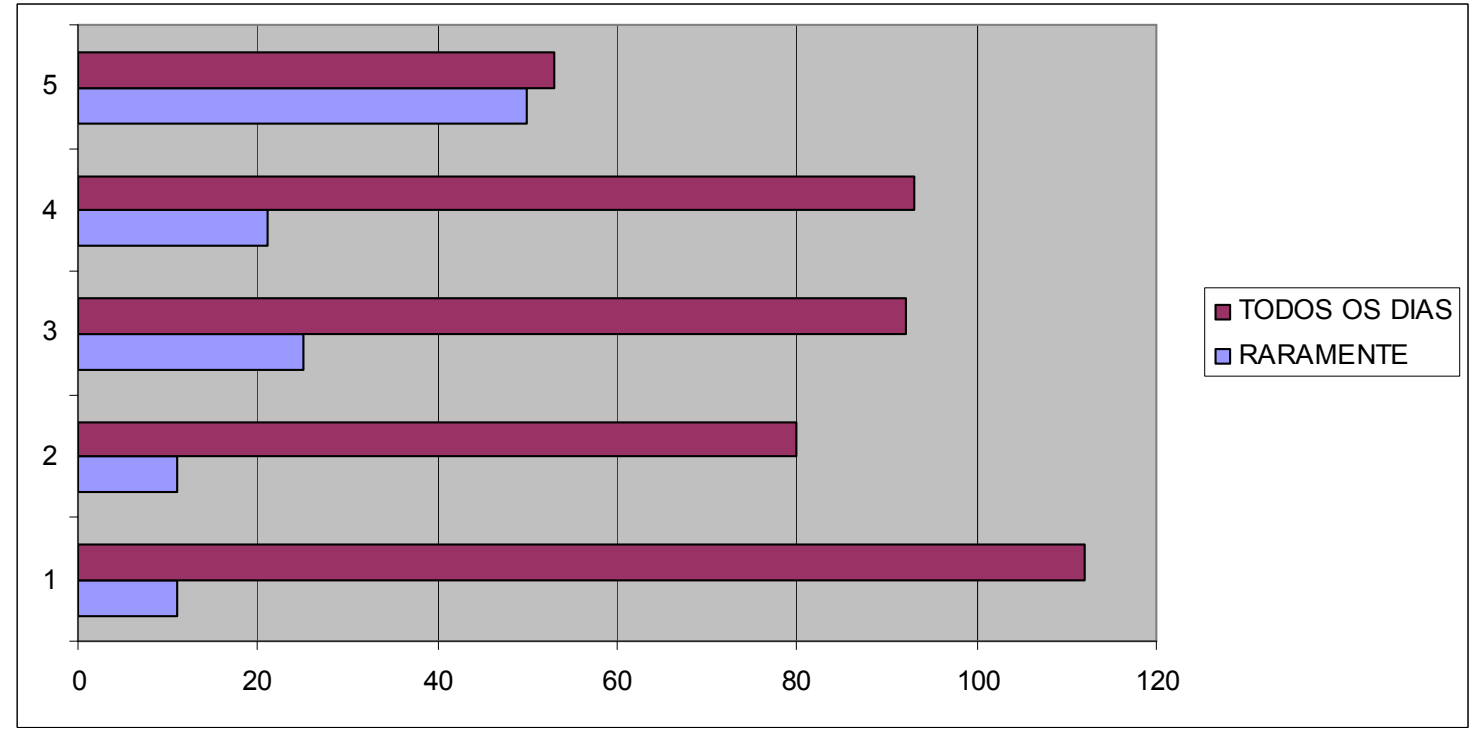

\begin{tabular}{|l|l|}
\hline D1 & Identifica as condições ambientais e sanitárias que promovem riscos para a saúde da comunidade \\
\hline D2 & Informa a equipe de saúde sobre a ocorrência de situações de risco, na microárea de atuação \\
\hline D3 & Informa a população sobre a ocorrência de situações de risco, na microárea de atuação \\
\hline D4 & $\begin{array}{l}\text { Orienta indivíduos e grupo quanto a medidas de redução ou prevenção de riscos ambientais e } \\
\text { sanitários em saúde }\end{array}$ \\
\hline D5 & Orienta moradores e famílias quanto a cuidados relacionados ao ambiente hospitalar \\
\hline
\end{tabular}


De certa forma, os ACS estão conseguindo realizar a ação de identificar "os problemas ambientais e sanitários que podem provocar riscos para a saúde da comunidade" (D1), pois $67,1 \%$ dos respondentes realizam-na diariamente. Entretanto, essa porcentagem cai para $47,9 \%$ e $55,1 \%$, respectivamente, para as ações D2 e D3: "informa à equipe e à comunidade sobre a ocorrência de situações de risco, na microárea de atuação". Na avaliação se o ACS “orienta os indivíduos em relação à redução ou prevenção de riscos ambientais e sanitários para a saúde" (D4), $55,7 \%$ realizam tal ação diariamente, e $12,6 \%$, raramente.

Em outro estudo de São Paulo, já citado, conclui-se que os ACS têm compreensão do processo saúde-doença e dos determinantes sociais desse processo. Porém, têm dificuldade em desenvolver ações de reflexão junto aos indivíduos e coletividades acerca de suas condições de saúde e doença, os seus determinantes e as formas de enfrentá-los, na perspectiva do empowerment individual e coletivo. Essa autora considera que tais dificuldades derivam da capacitação que os ACS recebem e do fato de as equipes da ESF ainda trabalharem tendo, como referencial, o modelo biomédico $^{46}$.

Já em relação à ação “orienta moradores e famílias quanto aos cuidados relacionados ao ambiente hospitalar" (D5), uma porcentagem pequena dos respondentes realiza-a diariamente $(31,7 \%)$. Possivelmente isso se justifica pelo fato de o ACS ter pouca proximidade a assuntos relacionados ao ambiente hospitalar, acompanhado do fato de ele ter pouca vivência neste ambiente, tornando-se uma tarefa dificultosa orientar o que não se conhece. Geralmente são poucos os usuários que necessitam cuidados hospitalares que podem ser realizados em domicílio; quando essa necessidade fica em torno de 30 dias, conforme o caso, o município conta com um programa de internação e interação domiciliar chamado (PROIID), composto por uma equipe multiprofissional, que vai até o domicílio, após a alta, orientar a família como proceder em relação aos cuidados básicos que esse usuário necessita. Nestes casos, a unidade de referência é acionada para ter conhecimento do caso e dar seguimento aos cuidados junto com a família. E o ACS é orientado como proceder e identificar situações que necessitem intervenções pontuais e imediatas. Esse resultado referente à orientação sobre cuidados relacionados ao ambiente hospitalar condiz com os achados em São Bernardo do Campo ${ }^{25}$. 
De certa forma, o ACS é capacitado para identificar, a todo o momento, problemas ambientais, seja na visita da dengue ou das prioridades. Aqui no município de Marília, o cumprimento de metas sobre as visitas da dengue são cobradas diariamente pelo supervisor da dengue.

Quando se questiona os usuários sobre quem é o ACS da sua área, os mesmos dificilmente sabem dizer o nome, reconhecem os ACS como "o(a) moço(a) que faz a visita da dengue". Talvez nem os usuários nem os próprios ACS saibam verdadeiramente qual é o papel deste profissional junto à comunidade, pois quem tem a responsabilidade de trabalhar isso junto da equipe de saúde é a equipe de referência - enfermeiro, médico e dentista, que também não têm clareza sobre o assunto.

5.2.5 Descrição e análise da competência E - "prevenção e monitoramento a grupos específicos e morbidades".

A competência "Prevenção e Monitoramento a Grupos Específicos e Morbidades" é composta por 23 ações. As respostas mostraram, mais uma vez, a prevalência da frequência "diariamente", com pequena incidência de "raramente" e "nunca", diferentemente dos outros eixos, em que os números encontrados na frequência "raramente" eram significativos. Em São Bernardo do Campo ${ }^{25}$, ocorreu a mesma semelhança.

Gráfico 9 - Distribuição da Frequência das ações realizadas pelos ACS relacionadas à competência E - Prevenção e monitoramento a grupos específicos e morbidades. Marília - 2009. 


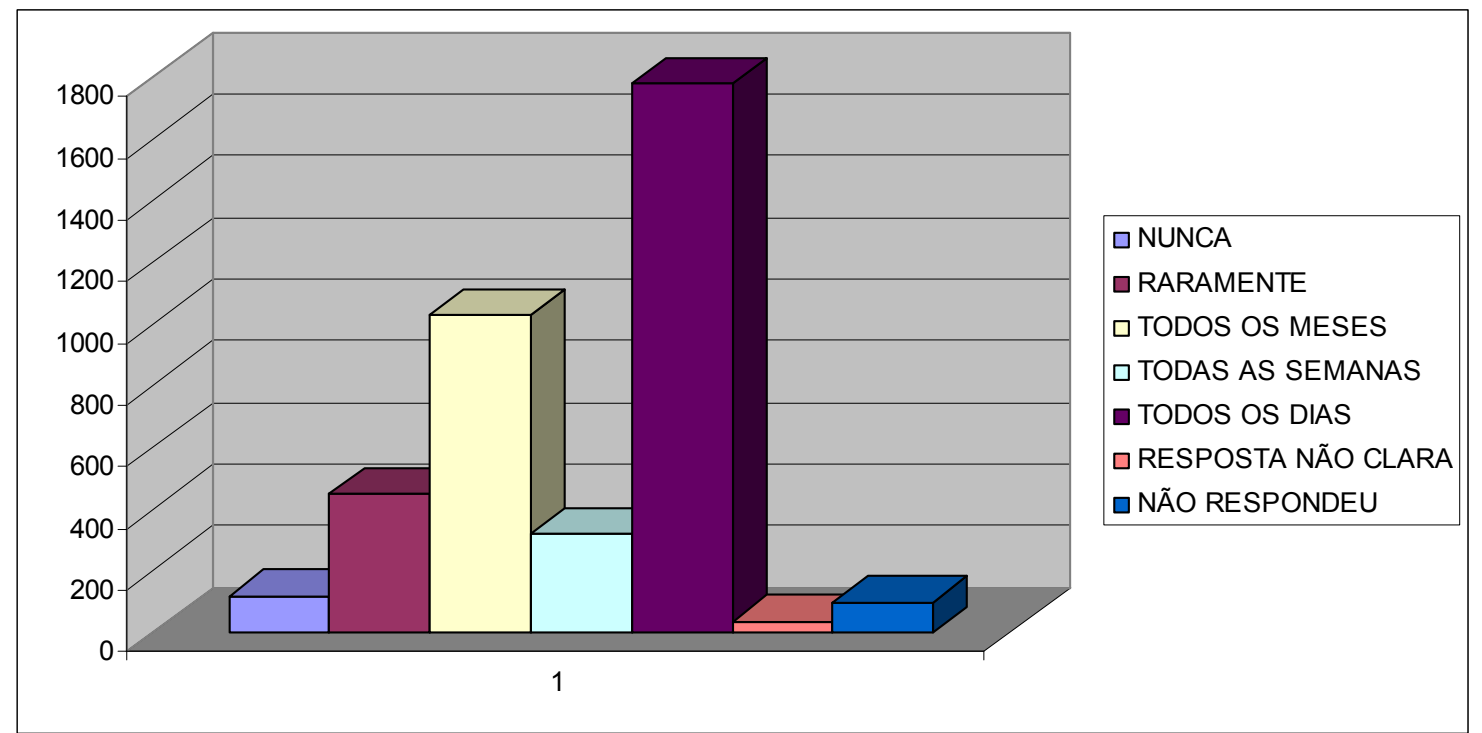

Gráfico 10- Frequência das ações realizadas raramente e diariamente pelos ACS na competência E - Prevenção e monitoramento a grupos específicos e morbidades. Marília-2009.

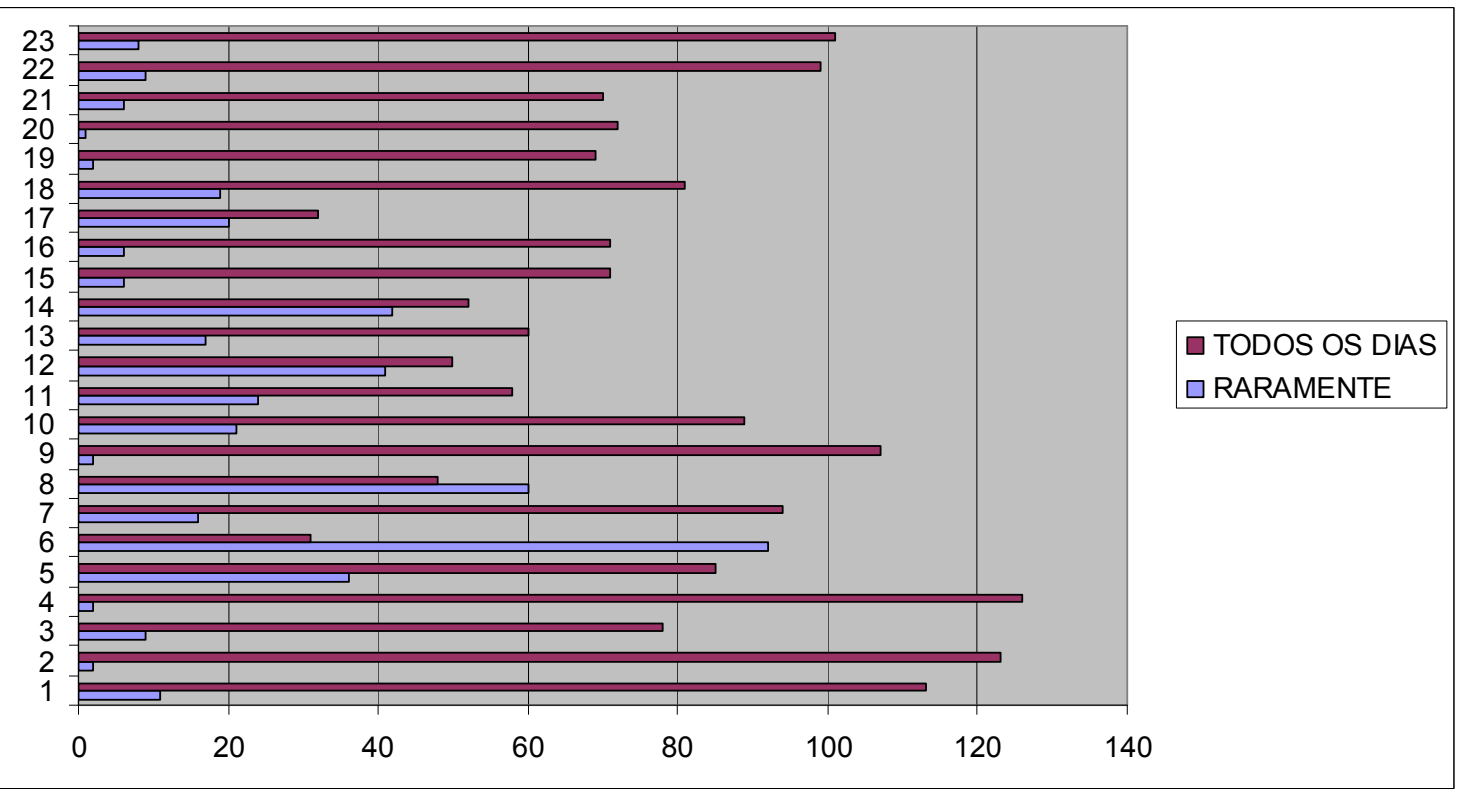

\begin{tabular}{|l|l|}
\hline E1 & Identifica indivíduos e grupos que demandam cuidados especiais de saúde \\
\hline E2 & Orienta a comunidade sobre sinais que indicam problemas de saúde \\
\hline E3 & $\begin{array}{l}\text { Comunica a equipe sobre casos existentes de indivíduos ou grupos que necessitem de cuidados } \\
\text { especiais ("grupos de risco", portadores de necessidades especiais e outros) }\end{array}$ \\
\hline E4 & $\begin{array}{l}\text { Ao identificar um problema de saúde nos indivíduos ou grupos, encaminha a UBS/ESF para } \\
\text { atendimento }\end{array}$ \\
\hline E5 & Agenda ou remarca consultas para a comunidade \\
\hline E6 & Leva medicação (conforme prescrição médica ou de enfermagem) para alguém da população \\
\hline E7 & $\begin{array}{l}\text { Sensibiliza os familiares e seu grupo social para a convivência com os indivíduos que necessitam } \\
\text { de cuidados especiais }\end{array}$ \\
\hline E8 & $\begin{array}{l}\text { Estimula indivíduos, famílias e grupos a participarem de programas sociais locais que envolvam } \\
\text { orientação e prevenção da violência intra e interfamiliar }\end{array}$ \\
\hline E9 & Orienta as gestantes sobre os cuidados relativos à gestação \\
\hline
\end{tabular}




\begin{tabular}{|l|l|}
\hline E10 & Orienta os familiares da gestante sobre os cuidados relativos à gestação \\
\hline E11 & Orienta as gestantes sobre os cuidados relativos ao parto \\
\hline E12 & Orienta os familiares da gestante sobre os cuidados relativos ao parto \\
\hline E13 & Orienta as gestantes sobre os cuidados relativos ao puerpério \\
\hline E14 & Orienta os familiares da gestante sobre os cuidados relativos ao puerpério \\
\hline E15 & Orienta gestantes, puérperas e grupo familiar quanto ao aleitamento materno \\
\hline E16 & Orienta gestantes, puérperas e grupo familiar quanto aos cuidados com o recém-nascido \\
\hline E17 & Solicita o passaporte materno-infantil nas visitas domiciliares \\
\hline E18 & Orienta indivíduos quanto à saúde sexual e reprodutiva \\
\hline E19 & Acompanha o crescimento infantil \\
\hline E20 & Acompanha o desenvolvimento infantil \\
\hline E21 & Solicita cartão de vacina nas visitas domiciliares \\
\hline E22 & $\begin{array}{l}\text { Orienta indivíduos e famílias sobre medidas de prevenção e controle das doenças não } \\
\text { transmissíveis }\end{array}$ \\
\hline E23 & Orienta indivíduos e famílias sobre medidas de prevenção e controle das doenças transmissíveis \\
\hline
\end{tabular}

$\mathrm{Na}$ análise relativa ao fato de o ACS identificar "indivíduos ou grupos que demandam cuidados especiais de saúde" (E1) e orientar "a comunidade sobre os sinais que indicam problemas de saúde" (E2), houve prevalência da frequência “diariamente", com respectivamente, 67,1\% e 73,7\%; quando se analisa se o ACS "comunica à equipe de saúde sobre os casos existentes de indivíduos ou grupos que necessitam de cuidados especiais" (E3), 46,7\% fazem-no diariamente, e 35,3\%, semanalmente. Uma baixa porcentagem de ACS, (3,6\%), ao identificar esses casos, não os encaminha para atendimento; a maioria, $(75,4 \%)$, diariamente encaminha-os para a unidade.

De uma maneira geral, o ACS é induzido a atentar mais aos grupos de risco e a realizar a visita domiciliária em busca de criadouros da dengue; mesmo as fichas A, $\mathrm{B}$ e C direcionam o trabalho deste profissional a sempre perguntar sobre tais problemas específicos. Percebe-se o fato acima na própria fala do profissional, ao cadastrar uma nova família: se ela não apresentar hipertenso, diabético, gestante, criança menor de cinco anos, alcoolista, portador de necessidade especial, caso de tuberculose ou hanseníase (exemplos de dados da ficha A, B e C), esta família é classificada como "normal".

O profissional não consegue entender que a saúde vai muito além da ausência das situações acima relatadas, pois a saúde vai muito além da ausência de doenças; é preciso que se enxergue a pessoa na sua totalidade, nas suas necessidades de saúde, como acesso ao lazer, moradia, trabalho, serviços de saúde, boa alimentação, bom relacionamento familiar, informação, levando-se em conta sua inserção nos grupos sociais e o quanto isso pode influenciar o processo saúde-doença dos indivíduos e famílias. 
A avaliação dos resultados mostra que, no município de Marília, existe a prática da ação "agenda ou remarca consultas para a comunidade" (E5) pelo ACS. Pode-se confirmar essa informação ao verificar que 50,9\% realizam-na diariamente e só $21,6 \%$ o fazem raramente. O ACS acaba fazendo essa tarefa ao ficar na recepção e ao agendar os retornos para a verificação de resultados dos exames realizados na unidade. No estudo realizado em São Bernardo ${ }^{25}$, os ACS não realizavam esse tipo de atividade. No estudo realizado em São Paulo aponta-se que os ACS também assumem tarefas nem sempre condizentes com suas atribuições. Algumas dessas tarefas são: agendamento/ remarcação de consultas e receitas do programa "remédio em casa". Os ACS também consideraram que ações como o recenseamento ou estatística de pessoas internadas, nascimentos, óbitos, etc., além do preenchimento de mapas de trabalho, demandam um tempo muito grande para execução e disputam com o tempo destinado às atividades na comunidade sob o olhar mais amplo da promoção da saúde ${ }^{46}$.

Geralmente o usuário procura a unidade quando sente necessidade de atendimento, seja ele espontâneo ou caso para agendamento, o qual é garantido apenas para retornos de acompanhamento da HAS, DM, pré-natal e puericultura; nesses casos, o usuário sai com o agendamento das próximas consultas em mãos.

Atualmente no município de Marília está se utilizando uma classificação de risco, por cores, para definição dos casos que devem ser atendidos em nível primário, secundário e terciário. Para as unidades de saúde, fica definido o atendimento das classificações de cor azul e verde (conforme o caso), verde para o prontoatendimento e amarelo e vermelho para o pronto-socorro. Foi uma tentativa de desafogar o sistema, que ainda se depara com o atendimento de nível terciário como porta de entrada em diversos momentos. Por outro lado, tal classificação sobrecarregou o atendimento das USF, que possuem apenas um médico para dar conta da demanda espontânea e agendada, além dos que recebem classificação azul, que não demandam atendimento imediato, mas cujo agendamento necessita ser feito para curto prazo.

Outra ação também não realizada com frequência pelos ACS é levar “medicação para alguém da população" (E6). Dos respondentes, 55,1\% relatam realizar essa ação raramente. Devido ao número reduzido de ACS, fica muito difícil essa prática; assim, a entrega na residência é feita apenas aos usuários que possuem 
dificuldades de locomoção e que não tenham ninguém para retirar a medicação. No trabalho realizado em São Bernardo do Campo $^{25}$, esse número foi de 24,9\%.

Os respondentes se preocupam com a inclusão social dos portadores de necessidades especiais, pois $56,2 \%$ dos respondentes procuram, diariamente, realizar a ação de sensibilizar "os familiares e seu grupo social para a convivência com indivíduos que necessitam de cuidados especiais" (E7); mas quando se trata do tema violência familiar apenas 28,7\% estimulam "indivíduos, família e grupos a participarem de programas sociais locais que envolvam orientação e prevenção da violência intra e interfamiliar" (E8), fato que pode ser justificado pela presença de diversas unidades de saúde que se localizam próximas a favelas, onde há domínio do tráfico de drogas. A interferência nessa dinâmica, ou até mesmo a ajuda à mulher de um líder do tráfico, para denúncia da violência doméstica, torna-se algo extremamente delicado e arriscado. No município de São Bernardo do Campo ${ }^{26}$, esse fato também foi observado.

Infelizmente a ajuda das autoridades nesses casos é escassa, e até mesmo inexistente; a lei do silêncio prevalece. Não existem casas de abrigo para aonde essa mulher possa ir para se proteger, ficando a mesma junto de seu agressor e nada é resolvido; essa mulher acaba sendo silenciada pela força do viver ou morrer, pelo medo de perder os filhos.

$\mathrm{O}$ trabalho junto às gestantes e puérperas se dá de forma satisfatória. O ACS procura quase mensalmente visitar essa família e "dar informações relativas ao prénatal, parto, puerpério, cuidados com o recém-nascido e aleitamento materno exclusivo até o sexto mês de vida, para a mulher e família", ações descritas nos itens 9 a 16 desta competência. Entretanto, é relevante notar que, respectivamente, 24,5\% e $25,1 \%$ dos respondentes relataram que raramente executam as ações relacionadas em E12: "orienta os familiares da gestante sobre cuidados relativos ao parto" e E14: “orienta os familiares da gestante sobre cuidados relativos ao puerpério". Esse fato é interessante, já que a maioria dos ACS são mulheres em idade adulta, com média de filhos de 1,7, variando entre as que não têm filhos e as que têm até seis. Assim, visto que elas detêm o conhecimento popular sobre a questão, o qual não entrou em contradição com o científico, questiona-se o motivo dessa falta de abordagem do puerpério, tanto para ser discutida na equipe, como trabalhada na comunidade. 
Talvez seja, mais uma vez, o fazer por fazer, sem reflexão sobre a prática. Ou, talvez, elas subestimem seu conhecimento popular.

A saúde sexual e reprodutiva (E18) é algo bem trabalhado pelos ACS, visto que o assunto é abordado nas visitas diariamente por 48,5\%; todos os meses, por $24 \%$, e raramente, por apenas $11,4 \%$. Eles estão bem subsidiados, pois as equipes de saúde sempre procuram trabalhar com os ACS a questão do planejamento familiar, coleta de material para exame de Papanicolau, mamografia anual e métodos contraceptivos disponíveis na unidade de saúde.

Na saúde da criança (E19), o ACS se mostra executando um trabalho satisfatório, pois 41,3\% fazem o acompanhamento diariamente, e 50,9\%, mensalmente; apenas $0,6 \%$ raramente acompanha o crescimento das crianças. $\mathrm{Na}$ continuidade da atenção à saúde da criança, o ACS executa a ação "solicita o cartão de vacina das crianças nas visitas domiciliárias" (E21) nos seguintes índices: 41,9\%, diariamente; $47,3 \%$, mensalmente, e $0,6 \%$, raramente.

Finalizando o acompanhamento das famílias, em 59,2\% e 60,4\% das visitas, o ACS “orienta indivíduos e famílias sobre as medidas de prevenção e controle de doenças transmissíveis e não transmissíveis” (E22, E23), respectivamente. Os índices dos que raramente realizam essas ações ficaram em apenas em 1,2\% e $0,6 \%$ das visitas, ou seja, no geral o ACS realiza de forma satisfatória tudo o que se relaciona a ações preventivas.

Ao se levar em conta as teorias de Promoção a Saúde ${ }^{33}$ e adotadas como quadro teórico para a presente pesquisa, percebe-se ser importante o ACS saber orientar o que se relaciona à saúde da mulher, da criança, doenças transmissíveis e não-transmissíveis, comunicar a equipe sobre usuários portadores de necessidades especiais; enfim, o que está previsto para ser cumprido pelo ACS na competência. Porém o ACS necessita ir um pouco mais além de tudo isso. Além de seu papel de orientar os indivíduos, ele precisa despertar, na comunidade, o reconhecimento de suas necessidades, e aí, partindo desse pressuposto, buscar maneiras de fortalecê-la no intuito de resolver essas demandas e buscar formas sustentáveis de intervenção. A proposta deste autor é a construção de uma comunidade organizada, que parte, não do recorte biológico para formação de grupos de atuação, mas, sim, de grupos que se unam em busca de um mesmo objetivo que não a cura das doenças, e, sim, da mudança dos determinantes sociais do processo saúde-doença. 


\subsubsection{Análise, com base em cruzamentos de ações complementares.}

No decorrer da análise dos dados apresentados pela pesquisa, foi possível identificar ações que, embora se complementassem, pertenciam a competências diferentes. Assim, avaliando essas possibilidades, foram realizados cruzamentos, que mesmo não possuindo valor estatístico, fornecem dados importantes para 0 entendimento de ações que, ora são realizadas, ora não, pelos ACS; principalmente no que se refere à Promoção da Saúde.

Pode-se observar, através destes cruzamentos complementares, que o ACS não consegue fazer a relação entre identificar problemas e informar isso a alguém, seja a equipe ou comunidade. Comprova-se tal assertiva ao comparar a ação D1: “identifica as condições ambientais e sanitárias que provoquem riscos para a saúde da comunidade" (D1) — que apresenta $67,1 \%$ na frequência "diariamente" —, com as ações D2 e D3: “informa à equipe de saúde e à população sobre a ocorrência de situações de risco na microárea de atuação"- cujas respostas para a freqüência "diariamente" foram de, respectivamente, $47,9 \%$ e 55,1\%. A diminuição da porcentagem confirma que, se o ACS identifica algo, não divide isso nem com a equipe e nem com a comunidade, fato de pode ser explicado por ainda ser mantida a ótica de atuação em torno da doença, e não dos determinantes sociais.

Comparando-se a porcentagem dos ACS que responderam que diariamente executam as ações D2 e D3: informa à equipe de saúde e à população sobre a ocorrência de situações de risco na microárea de atuação (índices acima), D4: orienta indivíduos e grupos quanto a medidas de redução ou prevenção de riscos ambientais e sanitários de saúde (55,7\%, número significativo) com a ação da Promoção de Saúde C7: "estimula os indivíduos e comunidade a refletir sobre suas condições de saúde e doença" - que apresenta um porcentual também significativo de ACS que realizam essa atividade diariamente $(65,2 \%)$ - fica o questionamento de como, e com qual qualidade, esse profissional realiza tais comunicações, e, por outro lado, como isso é trabalhado nas equipes de saúde. Será que o ACS não está apenas reproduzindo o que ele vive diariamente?

Com relação à comparação da ação "realiza atividades educativas sozinho para comunidade" (Competência Promoção da Saúde - C5), que apresenta 18,6\% na 
frequência "diariamente", com as ações D2 e D3 (informa à equipe de saúde e à população sobre a ocorrência de situações de risco na microárea de atuação), esse número se mostra bastante pequeno frente às ações D2 e D3 (47,9\% e 55,1\%, respectivamente). O ACS parece não conseguir utilizar seu maior instrumento de trabalho de maneira adequada: a comunicação! Fica então a dúvida de como ele realiza essas ações sem se comunicar com a comunidade.

Além dos cruzamentos das ações de algumas competências, também foram realizados outros cruzamentos de dados, com o intuito de entender se o modelo de atenção à saúde, em cada um dos órgãos, pode influenciar as ações de Promoção da Saúde. Para isso, utilizou-se a frequência de algumas ações da competência C Promoção da Saúde, realizadas por ACS da UBS, em comparação com seus colegas da ESF, sendo elas: $\mathbf{C 1}$ - Identifica a relação entre problemas de saúde e condições de vida, C2 - Identifica exemplos positivos que promovem a saúde na comunidade, C7 - Estimula indivíduos e a comunidade a refletirem sobre as suas condições de saúde e doença, C9 - Orienta a população quanto a medidas de proteção a saúde, C11 - Propõe ações que utilizem diversas secretarias existentes no município de Marília, C12 - Executa ações que atuam em parceria com outras secretarias existentes no município de Marília, C13 - Estabelece parcerias com creches, asilos, escolas, comerciantes, grupos sociais e outros e C16 - Participa de reuniões do conselho local de saúde ou de outros conselhos.

As tabelas abaixo mostram a frequência com que os ACS das UBS e das ESF, isoladamente, realizam cada uma das ações acima selecionadas. Para facilitar a análise, foram unidas as frequências "nunca" e "raramente", bem como "todos os dias/todas as semanas".

Tabela 4 - Distribuição da ação "Identifica a relação entre problemas de saúde e condições de vida" (C1) realizada pelos ACS da UBS e ESF isoladamente. Marília 2009.

\begin{tabular}{l|c|c|c|c} 
& Nunca/raramente & Porcentagem & $\begin{array}{c}\text { Todas as semanas/todos os } \\
\text { dias }\end{array}$ & Porcentagem \\
\hline UBS & 7 & 9,8 & 48 & $67,6 \%$ \\
\hline ESF & 6 & 6,2 & 77 & $80,2 \%$
\end{tabular}


Os dados percentuais acima, em relação à frequência diária/semanal das atividades, parecem indicar que os ACS que trabalham na ESF podem conceber seu trabalho e o processo saúde doença da comunidade de uma forma mais ampliada.

Realmente, a ESF pode auxiliar nessa maior amplitude de se conceber o trabalho em saúde e o processo saúde-doença. O trabalho nas USFs está baseado no acolhimento e no vínculo, bem como na co-responsabilização pela saúde; maneira esta de pensar o trabalho bem diferente das UBS tradicionais, onde há diversos especialistas da área médica, que trabalham, no máximo três horas por dia, no atendimento da demanda espontânea que procura a unidade e número definido de consultas. Nas sete horas restantes do dia, os casos são encaminhados para um dos PA, sendo que o da Zona Sul da cidade funciona das 7 às 19h, de segunda a sexta, e o da Zona Norte, 24h por dia. Esta é a situação da cidade, que tem uma média de 218 mil habitantes, além da população flutuante de duas universidades, um centro universitário e quatro faculdades. A lógica do atendimento, na maioria das vezes, é por ordem de chegada à unidade. Sendo assim, tem mais chance de ser atendido aquele que chega mais cedo, e não o que apresenta o pior quadro clínico. Isso fere os princípios do SUS relacionados à equidade e universalidade, já que não se leva em conta, ao menos, o porquê desse usuário ter procurado o serviço de saúde.

Tabela 5 - Distribuição da ação "Identifica exemplos positivos que promovem a saúde na comunidade" (C2) realizada pelos ACS da UBS e ESF isoladamente. Marília - 2009.

\begin{tabular}{l|c|c|c|c} 
& Nunca/raramente & Porcentagem & $\begin{array}{c}\text { Todas as semanas/todos os } \\
\text { dias }\end{array}$ & Porcentagem \\
\hline UBS & 7 & 9,8 & 48 & $67,6 \%$ \\
\hline ESF & 8 & 8,3 & 75 & $78,1 \%$
\end{tabular}

A análise comparativa mostra que os ACS da ESF parecem ter maior facilidade na identificação de potenciais parceiros no quesito interssetorialidade. Quando se fala em interssetorialidade, os ACS apresentaram certa dificuldade em identificar parcerias e lideranças em sua comunidade, e que, somente após o trabalho de educação permanente, isso começou a ser visto com um outro olhar e a ser percebido como algo fundamental no trabalho do ACS no reconhecimento dos 
determinantes de saúde e resolução dos problemas da comunidade. Essa dificuldade não foi identificada nessa pesquisa ${ }^{17}$.

Tabela 6 - Distribuição da ação "Estimula indivíduos e a comunidade a refletirem sobre suas condições de saúde e doença" (C7) realizada pelos ACS da UBS e ESF isoladamente. Marília - 2009.

\begin{tabular}{c|c|c|c|c} 
& Nunca/raramente & Porcentagem & $\begin{array}{c}\text { Todas as semanas/todos os } \\
\text { dias }\end{array}$ & Porcentagem \\
\hline UBS & 7 & 9,8 & 47 & $66,2 \%$ \\
\hline ESF & 3 & 3,1 & 78 & $81,2 \%$
\end{tabular}

Na comparação dos ACS de UBS e ESF, mais uma vez ficou demonstrado que, mais que os colegas da UBS, o ACS da ESF procura estimular nas comunidades o autocuidado, um ponto forte a ser trabalhado na busca pela Promoção da Saúde. Isso é discutido nas teorias de Promoção da Saúde utilizadas neste estudo ${ }^{33}$, que parte do princípio de que o levantamento dos problemas de saúde deve ser feito junto com a comunidade, com o objetivo de promover a autonomia dos sujeitos, na ótica da Promoção da Saúde. Neste cenário, o profissional de saúde apenas participa do processo como facilitador, analista/implementador ou mediador/defensor, com intuito de auxiliar o processo de autonomia dos sujeitos.

Tabela 7 - Distribuição da ação "Orienta a população quanto a medidas de proteção à saúde" (C9) realizada pelos ACS da UBS e ESF isoladamente. Marília 2009.

\begin{tabular}{c|c|c|c|c} 
& Nunca/raramente & Porcentagem & $\begin{array}{c}\text { Todas as semanas/todos os } \\
\text { dias }\end{array}$ & Porcentagem \\
\hline UBS & 1 & 1,4 & 58 & $81,6 \%$ \\
\hline ESF & 1 & 1,0 & 91 & $94,7 \%$
\end{tabular}

Na análise dessa ação, embora os ACS das duas unidades realizem-na com bastante frequência, há o predomínio, também, dos ACS da ESF, com 94,7\% contra $81,6 \%$ da UBS. Ao utilizar o modelo de dimensões de organização comunitária e construção de capacidade para análise ${ }^{33}$, percebe-se que o ACS da ESF, orientado pelo serviço de saúde, tende mais para o eixo do fortalecimento da unidade, porém o 
dado referente à UBS não se encontra tão discrepante. O ACS, ao praticar essa ação com maior frequência, pode contribuir para a diminuição de usuários que procuram a unidade de saúde em situações de demanda espontânea, fortalecendo a necessidade de acompanhamento da saúde antes de se adoecer, mas, de certa forma, são ações que ainda esbarram no modelo biológico de atuação. O ACS poderia realizar essa mesma ação com foco maior no eixo da comunidade e deixar que esta percebesse a necessidade de trabalhar formas para alcançar melhor qualidade de vida através da mudança dos determinantes sociais, como, por exemplo, uma forma de melhorar o desemprego, buscando alternativas de qualificação profissional.

Tabela 8 - Distribuição da ação "Propõe ações que utilizem as diversas secretarias existentes no município de Marília" (C11) realizada pelos ACS da UBS e ESF isoladamente. Marília - 2009.

\begin{tabular}{c|c|c|c|c} 
& Nunca/raramente & Porcentagem & $\begin{array}{c}\text { Todas as semanas/todos os } \\
\text { dias }\end{array}$ & Porcentagem \\
\hline UBS & 35 & 49,3 & 18 & $25,3 \%$ \\
\hline ESF & 61 & 63,5 & 13 & $13,5 \%$
\end{tabular}

Ao avaliar a ação acima, percebeu-se que os resultados foram pífios tanto nas UBS como ESF, donde se conclui que a relação com a esfera municipal do SUS se encontra fragilizada no município em questão.

De certa forma, esperava-se que o ACS da ESF tivesse maior facilidade para essas ações, pois, na maior parte do tempo, esse profissional tem um maior estímulo para se aprofundar nessas questões. Afinal, na efetivação da Promoção da Saúde não se pode trabalhar sozinho. Mesmo sendo o processo de construção comunitária empowerment algo interessante, existe a dificuldade de se colocar em prática essa ação, por ser este um processo que requer tempo integral de ação, confiança e compromisso dos atores nele envolvidos, e que comunidade e profissionais da saúde abandonem o poder ${ }^{33}$. Talvez, por isso, percebe-se que, às vezes, espera-se do ACS mais do que ele pode desempenhar, pois não basta estimular, é preciso que toda a equipe de saúde trabalhe com o mesmo objetivo, e não transfira a responsabilidade da resolução dos problemas para as comunidades, isentando o Estado de suas 
responsabilidades. Contudo, talvez o ACS seja a peça chave desse processo, por ser, ao mesmo tempo, profissional de saúde e integrante da comunidade.

Tabela 9 - Distribuição da ação "Estabelece parcerias com creches, asilos, escolas, comerciantes, grupos sociais e outros" (C13) realizada pelos ACS da UBS e ESF isoladamente. Marília - 2009.

\begin{tabular}{l|c|c|c|c} 
& Nunca/raramente & Porcentagem & $\begin{array}{c}\text { Todas as semanas/todos os } \\
\text { dias }\end{array}$ & Porcentagem \\
\hline UBS & 25 & 35,2 & 32 & $45,0 \%$ \\
\hline ESF & 37 & 38,5 & 35 & $36,4 \%$
\end{tabular}

Analisando-se os resultados, verifica-se que, de certa forma, o ACS da UBS tem maior facilidade em identificar em seu território as parcerias de que trata a ação acima. Esse dado complementa a discussão da ação C11 - Propor ações que utilizem as diversas secretarias existentes no município.

A fala de um trabalhador entrevistado, em um estudo realizado em um município do interior de São Paulo, mostra que os próprios trabalhadores do serviço de saúde não visualizam haver diferenças entre o trabalho da ESF e da UBS, a não ser em relação à definição de territórios prevista pela ESF. O profissional relatou perceber a unidade de saúde da família como um pronto atendimento, ou seja, um espaço essencialmente de doenças, e não de se buscar formas de intervenção direcionadas às necessidades da comunidade. Esta fala se mostra preocupante, pois se a ESF surgiu como uma forma de reorientar o modelo de atenção à saúde, isso parece não estar acontecendo e, muito menos, a realização de ações voltadas para a Promoção da Saúde e fortalecimento das comunidades ${ }^{43}$.

Tabela 10 - Distribuição da ação "Executa ações que atuam em parceria com outras secretarias existentes no município de Marília" (C12) realizada pelo ACS da UBS e ESF. Marília - 2009.

\begin{tabular}{l|c|c|c|c} 
& Nunca/raramente & Porcentagem & $\begin{array}{c}\text { Todas as semanas/todos os } \\
\text { dias }\end{array}$ & Porcentagem \\
\hline UBS & 43 & 60,5 & 17 & $23,9 \%$ \\
\hline ESF & 61 & 63,5 & 21 & $21,8 \%$
\end{tabular}


O ACS mostra-se capaz de identificar as parcerias na comunidade, mas quando precisa executar intervenções junto a essas secretarias, esse número cai abruptamente na frequência "todos os dias" e "todas as semanas" (você pode trocar essas aspas pelos adjetivos: frequência diária e semanal. Em relação à freqüência "raramente", talvez possa modificar para frequência rara. Entre os que responderam que raramente (ou nunca) realizam a ação, o índice foi maior para os profissionais da ESF. O esperado era que essa ação fosse muito mais realizada pelos ACS da ESF, mas não é isso o que essa pesquisa demonstra: as ações de interssetorialidade, no município em geral, se encontram fragilizadas.

Tabela 11 - Distribuição da ação "Participa de reuniões de conselho local de saúde ou de outros conselhos locais" (C16) realizada pelos ACS da UBS e ESF. Marília - 2009.

\begin{tabular}{c|c|c|c|c} 
& Nunca/raramente & Porcentagem & $\begin{array}{c}\text { Todas as semanas/todos os } \\
\text { dias }\end{array}$ & Porcentagem \\
\hline UBS & 40 & 56,3 & 28 & $39,4 \%$ \\
\hline ESF & 79 & 79,1 & 18 & $18,7 \%$
\end{tabular}

Os dados acima mostram que é grande a quantidade de ACS que nunca/raramente participam de reuniões de conselho, seja ele de saúde ou não. Esperava-se o contrário em relação aos ACS da ESF, vez que eles possuem a prática mensal da reunião da comunidade. Dos dados apresentados, é possível levantar, pelo menos, duas hipóteses de conclusão: a) estes profissionais estão cansados de reuniões em que muito se discute e nada muda; ou b) eles não têm, ainda, grande consciência de cidadania, e preferem deixar que outros tomem a iniciativa de resolver os problemas que o afetam diretamente.

Deve-se ter o cuidado, também, para não colocar sob total responsabilidade da comunidade a resolução de seus problemas. Ao se focar nas necessidades da comunidade para a construção da capacidade comunitária, o governo tem a responsabilidade de divulgar os direitos e deveres dos cidadãos. Outro cuidado que se deve tomar ao se trabalhar com as lideranças da comunidade refere-se a “empoderar" quem já está "empoderado" e continuar marginalizando aqueles que são desprivilegiados ${ }^{35}$. 
Ao retomar o modelo de dimensões de organização comunitária e construção de capacidade, percebemos que as ações de cidadania se encontram no eixo do fortalecimento comunitário, o qual deve ser realizado pela comunidade, porém, ao mesmo tempo, pelos serviços qualificados. Assim, a cidadania pode auxiliar as comunidades, se for utilizada de maneira a fortalecê-las, partindo de sua necessidade de conhecimento e aplicação $\mathrm{O}$ ato de realizar algo, sem saber ao certo o que significa, que origens tem e que consequências terá, revela uma ausência do sentimento de cidadania, revela um ser autômato, conhecido popularmente como pau mandado, facilmente transformável em massa de manobra.

Pouca ou nenhuma participação dos ACS foi constatada, em um estudo realizado em São Paulo, nas reuniões e atividades do conselho local de saúde e demais conselhos das áreas sociais, incluindo o conselho tutelar. Observou também que não havia um trabalho do ACS de mobilização da população para participar dessas reuniões. A autora considera que a participação em instâncias colegiadas de decisão e fiscalização é fundamental para exercer o controle cidadão sobre os órgãos e serviços públicos e, dessa forma, exercer poder e expressar a cidadania ${ }^{46}$.

$\mathrm{Na}$ análise geral desses cruzamentos, envolvendo algumas ações da competência C e os ACS de UBS e ESF, houve um predomínio do trabalho do ACS da ESF nas ações de identificar a relação entre os problemas de saúde e condições de vida $(\mathrm{C} 1)$, identificar exemplos positivos que promovem a saúde na comunidade (C2), estimular os indivíduos e a comunidade a refletirem sobre as suas condições de vida e doença $(\mathrm{C} 7)$ e orientar a população quanto a medidas de proteção a saúde (C9). O esperado era que, a todo o momento, o ACS inserido na ESF apresentasse melhor desempenho, pois estariam melhores preparados para lidarem com o atendimento à comunidade de forma mais integral, levando em conta todo o processo saúde-doença na construção do cuidado.

Já no que se refere a propor ações que utilizem as diversas secretarias existentes no município (C11), executar ações que atuam em parceria com outras secretarias existentes no município (C12), estabelecer parcerias com creches, asilos, escolas, comerciantes, grupos sociais e outros $(\mathrm{C} 13)$ e participar de reuniões do conselho local de saúde ou de outros conselhos locais (C16), houve um predomínio dos ACS da UBS, ou seja, no que se refere às ações de interssetorialidade e controle social, esses ACS mostram ter maior facilidade e articulação. 
Nos trabalhos realizados em São Bernardo do $\mathrm{Campo}^{25}$ e São Paulo ${ }^{23}$, percebe-se, também, que as ações de Promoção à Saúde não são realizadas como deveriam ser, pois observou-se o predomínio das ações individuais em detrimento das coletivas. Merece destaque a discussão sobre o trabalho em equipe, que aponta que sua limitação está atrelada à falta de comunicação entre seus membros, devido à falta de tempo e sobrecarga de atividades. O trabalho em equipe aumenta o reconhecimento das necessidades da comunidade e a produção de ações de saúde com foco na integralidade. Com isso, pode-se concluir que a mudança deve ocorrer na equipe como um todo, e não somente no trabalho do ACS, sendo tal trabalho reflexo da equipe e, ao mesmo tempo, da comunidade ${ }^{43}$, lembrando, ainda, que não é fácil implementar a construção comunitária baseada no empowerment ${ }^{33}$.

Em seu estudo, realizado em São Paulo, que caracteriza o que seria uma prática "empoderadora" do ACS, utilizou-se para sua análise o modelo analítico elaborado por Labonte, que consiste em cinco esferas, a partir das quais os indivíduos vão ampliando seu poder: autocuidado, desenvolvimento grupal, organização comunitária, coalizão para reivindicação e ação política. Ao relacionar a prática "empoderadora" com os ACS, o autor avalia que o vínculo que o ACS deve estabelecer com sua comunidade é um dos pontos importantes para que possa contribuir com o "empowermnent" de indivíduos, grupos e da própria comunidade. Nesse estudo também fica marcado que, na integração dos ACS com os grupos sociais, a prática "empoderadora" esperada fica prejudicada se os grupos ficam focados apenas em relação a agravos à saúde e se a abordagem do ACS for normativa e prescritiva (como foi observado na pesquisa). Tal situação reproduz a prática pouco transformadora e emancipatória dos demais profissionais da $\mathrm{ESF}^{47}$.

Um caminho para a efetivação da Promoção da Saúde seria o desenvolvimento do "empowerment comunitário", o qual se encontra relacionado às estratégias que promovem a participação social e o controle das pessoas sobre suas próprias vidas. Com isso, pode ocorrer um aumento da capacidade dos indivíduos e da coletividade de intervir nos problemas de saúde. Tal intervenção seria organizada a partir de uma postura reflexiva sobre seus próprios problemas ${ }^{27}$. 
CONSIDERAÇÕES FINAIS 


\section{CONSIDERAÇÕES FINAIS}

Esta pesquisa buscou descrever e analisar as ações realizadas pelos ACS no município de Marília (SP), buscando enfocar mais especificamente o potencial do ACS para a promoção da saúde na perspectiva do fortalecimento da comunidade. Para tanto a pesquisa buscou traçar o perfil demográfico dos ACS do município de Marília, além de descrever a frequência com que esses profissionais realizam as ações que compõem as cinco competências propostas pelo Ministério da Saúde ${ }^{14}$ para esse novo profissional de saúde. Buscou-se ainda neste estudo identificar como o modelo de atenção à saúde pode interferir no desempenho das ações de promoção saúde. O quadro teórico utilizado para a análise dos dados baseou-se no livro "Theory in a Nutshell - A practical guide to health promotion theories", mais especificamente a teoria que toma como base a organização comunitária e a construção comunitária ${ }^{33}$.

Assim encontrou-se que o retrato do ACS no município de Marília não se diferencia do de outros municípios ${ }^{10,25,24,23,43}$. Os ACS, na sua maioria, são do sexo feminino, nascidos na Região Sudeste, cor branca, casados ou com relação estável, com ensino médio completo. Possuem casa própria, morando no bairro em que trabalham há 16 anos, em média; idade média de 38 anos e enxergaram na profissão de ACS uma oportunidade de emprego. A média de tempo de trabalho na ESF/PACS ficou em torno de 5,2 anos. Anterior à profissão de ACS, a profissão mais citada como exercida foi a de recepcionista, sendo que, na sua maioria, possuíam carteira assinada e média salarial familiar em torno de R\$1.260,00.

Já em relação às cinco competências propostas pelo MS (2004) ${ }^{14}$ - Integração da equipe com a população local (A), Planejamento e Avaliação (B), Promoção da Saúde (C), Prevenção e Monitoramento de Risco Ambiental e Sanitário (D) e Prevenção em Monitoramento a Grupos Específicos e Morbidades (E), a frequência prevalente foi a realização diária das ações, havendo somente na competência $\mathrm{C}$ um empate nas frequências "todos os dias" e "raramente". O que mostrou que de modo geral os ACS executam ações relacionadas as competências para ele desenhadas pelo 
MS (2004), com uma pequena confusão no que tange a competência de promoção da saúde .

$\mathrm{Na}$ avaliação da competência A (integração da equipe com a população local), houve prevalência das ações na frequência "todos os dias" e a ação mais realizada foi "orienta a comunidade sobre o funcionamento da UBS/USF, atividades e campanhas". Conforme a classificação das dimensões de organização comunitária e capacidade de construção ${ }^{33}$, percebe-se ser esta ação fortemente direcionada ao eixo voltado às doenças, sendo realizada, principalmente, pelos serviços de saúde. No oposto de participação, a ação que mais raramente é executada é: “expõe suas opiniões nas reuniões em equipe". Assim, é possível perceber falhas na comunicação entre os profissionais de uma mesma equipe de saúde, principalmente no que tange ao ACS, que, ao que parece, pratica ações mecanizadas buscando, apenas, o cumprimento de metas estabelecidas.

Fica o questionamento: se o Ministério da Saúde propõe atribuições baseadas em cinco competências de atuação para direcionar o trabalho do ACS, por que então não reformular o instrumento de trabalho do ACS e da equipe para algo que realmente reflita os perfis de saúde-doença da área adscrita e proporcione ações de vigilância à saúde e não a doenças? Talvez seja essa uma estratégia que desperte, na equipe, formas diversas de enxergar a realidade de um território e, assim, trabalhar dando mais voz ao ACS.

Na avaliação geral da competência B (Planejamento e Avaliação), também prevaleceu a frequência "diariamente"; a ação que sobressaiu nessa competência foi "Incentiva a população a participar de atividades de sua própria comunidade". Tal resultado é interessante, visto que o ACS não consegue expor suas opiniões em equipe, mas na comunidade consegue realizar ações que divulgam as potencialidades da própria comunidade (grupos na unidade de saúde ou ONG, por exemplo). As questões que se levantam são: como isso é feito na prática? De que forma o ACS aborda um usuário para participar de algo disponível na sua comunidade?

Quando se avalia a principal competência dessa pesquisa, a Promoção da Saúde (C), percebe-se um empate nas frequências "todos os dias" e " raramente". O que isso pode refletir? O esperado era que houvesse um predomínio na frequência diária. Afinal, acredita-se ser a Promoção da Saúde um "campo de saberes e práticas" que fortalece a comunidade no entendimento dos determinantes do processo saúde- 
doença para, a partir daí, ocorrer a busca de ambientes mais saudáveis e formas de vida mais estruturada. E o ACS não tem um conhecimento "clinico - biológico"e sim um conhecimento "sobre hábitos e modos de viver da comunidade" o que implicaria em se esperar dele mais ações voltadas para a promoção da saúde do que para a prevenção da doença.

Assim, tomando como base as dimensões de organização comunitária e capacidade de construção (pag. 44, quadro teórico), as ações de Promoção da Saúde, deveriam estar no eixo de fortalecimento da comunidade, fortalecimento esse direcionado pela própria comunidade, mas, na realidade, o que se tem são ações voltadas principalmente para os problemas de saúde ${ }^{33}$. A ação "orienta a população quanto a medidas de proteção à saúde" merece destaque pela frequência "diariamente", e as ações "executa ações que atuem em parceria com outras secretarias existentes no município" e "participa de reuniões do conselho de saúde ou de outros conselhos", pela frequência "raramente", o que afirma que o ACS está preparado apenas para identificar problemas na sua comunidade, mas não está preparado para refletir e intervir sobre eles, muito menos identificar estratégias para a construção da interssetorialidade. Talvez toda a equipe de saúde não esteja preparada para isso. Como fortalecer a comunidade se seu principal representante não está preparado para isso?

No levantamento bibliográfico realizado para definir o objeto de estudo desta pesquisa, observou-se que o ponto chave é a capacitação do ACS, porém não se pode atribuir toda essa responsabilidade a um único integrante da equipe de saúde, principalmente se trabalhamos em equipe. De que forma poderia ser feita essa capacitação? A teoria de Promoção da $S^{2}$ úde $^{33}$, adotada nesse estudo, fala que o levantamento dos problemas da comunidade seja feito juntamente com ela; ao se transferir esse mesmo raciocínio para a realidade dos ACS e das equipes das unidades de saúde da família, a sugestão fica então em se iniciar, juntamente com os ACS, a partir do levantamento das necessidades desses profissionais, a construção de um programa de capacitação, utilizando-se metodologias ativas de aprendizado.

$\mathrm{Na}$ competência D (Prevenção e monitoramento de risco ambiental), o que prevalece são as ações na freqüência "todos os dias", com destaque para a ação "identifica as condições ambientais e sanitárias que provoquem riscos para a saúde da comunidade". Por outro lado, a ação "orienta moradores e famílias quanto aos 
cuidados relacionados ao ambiente hospitalar" destaca-se na frequência "raramente". Como tais cuidados não fazem parte da prática do ACS, percebe-se a razão das respostas encontradas. Além disso, como seu trabalho é somente de identificação, quando ele se depara com algo que não conhece, aquilo se torna sem sentido, até mesmo para buscar informações sobre o quanto tais cuidados podem interferir na qualidade de vida de um usuário, nos riscos ambientais e condutas falhas da equipe de saúde.

Ao avaliar a competência E (Prevenção e monitoramento a grupos específicos e morbidades), observa-se a ação “ao identificar um problema de saúde nos indivíduos ou grupos, encaminha à UBS/USF para atendimento" como a que apresenta maior porcentagem na frequência "todos os dias" e a ação "leva medicação para alguém da população" como a de maior prevalência na freqüência "raramente". A lógica de trabalho do ACS mantém-se centrada em ações que buscam sanar o problema relacionado à patologia ou alteração física; desta forma, nada mais que natural encaminhar este usuário para o serviço de saúde.

Em artigo, que busca analisar o processo de construção da identidade do ACS, a partir de sua inserção na equipe da ESF e da interação com moradores do bairro onde reside, os autores tomam como base duas ações propostas pelo Ministério da Saúde e, com base na avaliação dessas ações, fazem a discussão do movimento bi-direcional realizado pelo ACS: o que se relaciona à informação sobre "modos de fazer", informação essa orientada pelo modelo biomédico, e o que se relaciona ao direcionamento dado à equipe de saúde para o entendimento dos problemas de saúde e necessidades da comunidade. Em outra discussão presente neste mesmo artigo, os autores falam sobre a capacitação do ACS para a realização de procedimentos técnicos como verificação de peso, altura, cartão vacinal, além do desenvolvimento de práticas educativas (hábitos de higiene, alimentação) ${ }^{48}$. O que se observa é que, a todo o momento, o ACS é direcionado para lidar com os aspectos biológicos do processo saúde-doença. Assim, provavelmente o que ele irá conseguir identificar em seu território serão somente problemas relacionados à doença, e não aos determinantes sociais da saúde.

Em relação à questão de o ACS levar medicamentos nas residências, essa prática só é realizada no município de Marília em extrema necessidade, devido ao número reduzido de recursos humanos (ACS) das unidades de saúde. Por outro lado, 
essa ida ao domicílio para levar a medicação, poderia ser um espaço para o ACS despertar no usuário o interesse em mudar sua condição de vida, momento no qual este profissional poderia propor o que é possível fazer para melhorar sua situação atual, convidá-lo para as reuniões de comunidade, conselhos de saúde, divulgar as atividades disponibilizadas pela unidade de saúde e comunidade, fazer o usuário pensar um pouco sobre suas práticas de lazer, relacionamento familiar; enfim, explorar aspectos que em outras visitas não são abordados com tanta frequência.

Ao refletir sobre as ações desempenhadas pelos ACS de Marília - SP e o observado em outros trabalhos citados nessa pesquisa ${ }^{10,25,24,23,43}$, conclui-se que o ACS deste município, quando começou a desempenhar suas funções, mal sabia o que realmente deveria fazer; somente com a prática diária, foi se aproximando do que se tem hoje.

Não basta a publicação de suas competências pelo Ministério da Saúde para que o profissional comece a desempenhar algo que nem mesmo a equipe de saúde tem o conceito correto. Com isso, o ACS não consegue no trabalho do dia a dia, através da visitas domiciliárias, desempenhar seu papel de protagonista na construção de vínculos, bem como não consegue ser o intermediador entre o conhecimento cientifico e popular, nem pautar seu trabalho no fortalecimento da relação comunidade e serviços de saúde ${ }^{49}$. Dessa maneira, seu trabalho se resume no fazer por fazer, sem a reflexão da ação e, desse modo, o que isso pode contribuir para melhorias na qualidade de vida das comunidades?

Uma explicação para isso, pode se relacionar ao processo de formação, inserção e prática do ACS, pois existe a dificuldade desse profissional em se inserir nas equipes de saúde e a definição de sua função; já que, muitas vezes, seu processo de capacitação é realizado separadamente dos demais membros da equipe. Esse sentimento também se encontra presente nos auxiliares de enfermagem ${ }^{49}$.

$\mathrm{O}$ que se percebe atualmente é a presença de modelos assistenciais complementares ou contraditórios, tal como o modelo médico assistencial privatista, prática consolidada há anos na sociedade, com enfoque basicamente biologicista e de ações curativas $^{44}$.

Em paralelo coexiste um modelo assistencial sanitarista, orientado por ações epidemiológicas e sanitárias, que enfatiza a importância de se explicar o processo saúde-doença, e articula ações interssetoriais gerando intervenções específicas na 
promoção da saúde ${ }^{44}$. A existência de dois ou mais modelos de atenção pode interferir, de certa forma, no trabalho da equipe de saúde. Afinal, se cada profissional olhar o indivíduo de uma maneira particular, as práticas de saúde serão as mais diversas possíveis e dificilmente complementares, o que difere do que se busca com a ESF.

Ao assumir a proposta do modelo assistencial sanitarista, a ESF se destaca por ser uma proposta de mudança da concepção tradicional do processo saúdedoença. Nele, o ACS também ajuda na descentralização da figura do médico, pois a população passa a procurar o ACS para falar o que está acontecendo com sua saúde ${ }^{44}$.

$\mathrm{Na}$ ESF, pelo trabalho ser organizado multiprofissionalmente, o médico e enfermeiro não assumem apenas o papel de atender o paciente doente, mas são feitas visitas domiciliárias e, ao identificar alterações na casa de um usuário, torna-se necessário fortalecer o papel do ACS em estimular a mudança do estilo de vida. Esse discurso é compartilhado por toda a equipe de saúde ${ }^{44}$.

Um artigo procurou retratar a percepção do ACS sobre o programa Família Saudável, com o objetivo de identificar as potencialidades e fragilidades para a mudança do modelo de atenção. As autoras também observaram haver o predomínio de ações de identificação e resolução de problemas de saúde pautados na recuperação do corpo físico, mas, por outro lado, notaram que, ao realizar a visita domiciliária, mesmo não sendo o objeto de atuação dos ACS as necessidades de saúde, há indícios da um conceito de saúde mais ampliado, o que sugere um momento de transição nas concepções e práticas com base na saúde pública tradicional, para uma forma de entender o processo saúde-doença conforme proposto pelo $\mathrm{SUS}^{50}$.

Outro fator importante presente na fala do ACS, que pode estar interferindo no trabalho da ESF, relaciona-se à alta rotatividade de profissionais, aspecto que dificulta a criação de vínculo, tanto junto à equipe como à comunidade. E este é um problema: o ACS deseja maior segurança no seu trabalho para desempenhar seu papel na consolidação do SUS. As autoras concluem que a ESF tem alcançado seu objetivo de mudança no modelo de atenção à saúde atual, porém ainda precisa se consolidar técnica e politicamente, para promover mudanças nas práticas de saúde. Elas destacam, também, a importância do trabalho do ACS para que isso se efetive realmente ${ }^{49}$. 
São diversas as percepções sobre a ESF e as ações desempenhadas pelos ACS; a todo o momento há esforços para a mudança da concepção biomédica do processo saúde-doença, mas por que o conceito de saúde, em muitos momentos, é entendido como ausência de doenças?

Discorrendo sobre esse problema, percebe-se existir uma forte ligação entre a Medicina e Biologia; isto porque, no decorrer da história, estas caminharam juntas, havendo na Medicina uma forte tendência mecanicista da vida, tendência essa que foi estabelecida pela Biologia. Assim, a Medicina sofreu grande influência dos pensamentos cartesianos, o que resultou no modelo biomédico, que domina até hoje as práticas dos trabalhadores da saúde. O corpo humano é visto, então, como uma “máquina" composta por peças, e a doença representa um defeito passível de "conserto" " Sendo visto de forma fracionada, o corpo humano resulta nas diversas especialidades médicas. Esta é, também, a visão da comunidade, que prefere ser avaliada pelo especialista (que olha as "partes") do que pelo médico da família (que olha o todo). A finalidade do trabalho da equipe de saúde se resume a tratar a doença, e não o ser humano, ressaltando os aspectos biológicos e alívio da dor ${ }^{43}$. O que é possível perceber no dia a dia de trabalho é que esse pensamento, baseado na doença, ainda está presente nas equipes de saúde; afinal, é difícil a mudança de conceitos enraizados.

Como modificar tal situação? Através de um trabalho com toda a equipe de saúde, com base nos princípios da educação permanente, com foco na Promoção da Saúde proposta no livro Theory in a nutshell: a practical guide to health promotion theories $^{33}$, como já evidenciado nessa pesquisa. A sugestão, então, é partir da realidade de cada equipe de saúde, cada território, e levantar as demandas, tanto da equipe quanto da comunidade, a fim de se partilhar saberes científicos e populares, na busca da mudança do entendimento do processo saúde-doença, com vistas a mudanças nos determinantes sociais e ao fortalecimento da comunidade e dos profissionais da saúde, sem, obviamente, esquecer que todos são protagonistas nesse processo, inclusive o Estado, e, assim, devem participar ativamente do processo. 


\section{REFERÊNCIAS}




\section{REFERÊNCIAS}

1. Franco T, Merhy EE. PSF: contradições e novos desafios. In: Conferência Nacional de Saúde On-Line. Tribuna Livre. 1999 [citado 2008 jun. 19]; [cerca de 9 p.]. Disponível em: http://www.datasus.gov.br/cns/temas/tribuna/PsfTito.htm

2. Dowbor TP. O trabalho com determinantes sociais de saúde no Programa Saúde da Família no município de São Paulo. [Tese]. São Paulo: Faculdade de Saúde Pública, Universidade de São Paulo, 2008.

3. Brasil. Ministério da Saúde. Portaria no 648, de 28 de março de 2006. Aprova a política nacional de atenção básica, estabelecendo a revisão de diretrizes e normas para organização da atenção básica para o programa saúde da família (PSF) e o programa de agentes comunitários de saúde (PACS). [legislação na internet]. Brasília; 2006 [citado 2010 jan. 28]. Disponível em: http://dtr2004.saude.gov.br/dab/legislacao/portaria_648_28_03_2006.pdf. Acesso em 28 jan. 2010.

4. Sousa MF. A enfermagem reconstruindo sua prática: mais que uma conquista no PSF. Rev Bras Enferm. 2000;53(n. esp):25-30.

5. Brasil. Ministério da Saúde. Guia prático do Programa Saúde da Família. [citado 2010 jan.28]. Disponível em: http://www.saude.gov.br/psf/index.htm(publicações).

6. Brasil. Ministério da Saúde. Secretaria de Atenção Básica. Departamento de Atenção Básica. Política Nacional da Atenção Básica (PNAB). Série Pactos pela a Vida, vol 4, 2006. [citado 2010 jan. 30]. Disponível em: http://bvsms.saude.gov.br/bvs/publicacoes/politica_nacional_atencao_basica_ 2006.pdf.

7. Brasil. Ministério da Saúde. Promoção da Saúde. Brasília; 2001.

8. Silva JA, Dalmasso ASW. O agente comunitário de saúde e suas atribuições: desafios para os processos de formação de recursos humanos em saúde. Interface Comum. Saúde Educ. 2002;6(10):75-83. 
9. Morosini MV, Corbo A D'Andrea, Guimarães CC. O agente comunitário de saúde no âmbito das políticas voltadas para atenção básica: concepções do trabalho e da formação profissional. Trab. Educ. Saúde. 2007;5(2):261-80.

10. Silva JA. O agente comunitário de saúde do Projeto Qualis: agente institucional ou agente de comunidade? [Tese]. São Paulo: Departamento de Prática de Saúde Pública, Universidade de São Paulo; 2001.

11. Carvalho VLM. A prática do Agente comunitário de saúde: um estudo sobre sua dinâmica social no município de Itapecerica da Serra [dissertação]. São Paulo: Faculdade de Saúde Pública, Universidade de São Paulo; 2002.

12. Silva JA, Dalmaso ASW. Agente comunitário de saúde: o ser, o saber, o fazer.Rio de Janeiro:Fiocruz;2002. [Resenha de: Mendonça MHN, Cad Saúde Pública. 2004;20(5):197-203]

13. Chiesa AM, Fracolli LA. O trabalho dos agentes comunitários de saúde nas grandes cidades: análise do seu potencial na perspectiva da promoção da saúde. Rev Bras de Saúde da Fam (Brasília)2004;2:42-9.

14. Brasil. Ministério da Saúde. Perfil de competências do agente comunitário de saúde. Brasília; 2004.

15. Brasil. Lei $\mathrm{n}^{\circ} 11.350$, de 5 de outubro de 2006. Dispõe sobre as atividades do agente comunitário de saúde e o agente de combate às endemias e dá outras providências. [legislação na internet]. Brasília; 2006 [citado 2010 jan.30]. Disponível em: http://www.planalto.gov.br/ccivil_03/_Ato20042006/2006/Lei/L11350.htm.

16. Kluthcosky ACGC, Takayanagui AMM. Community health agent: a literature review. Rev. latinoam. enferm 2006;14(6):957-63.

17. Duarte LR, Silva DSJR, Cardoso SH. Construindo um programa de educação com agentes comunitários de saúde. Interface Comum. Saúde Educ. 2007;11(23):439-47.

18. Martines WRV, Chaves EC. Vulnerabilidade e sofrimento no trabalho do agente comunitário de saúde no Programa de Saúde da Família. Rev. Esc. Enferm. USP 2007;41(3):426-33.

19. Rosa AS, Cavicchioli MGS, Brêtas ACP. O significado que o agente comunitário de saúde atribui ao seu trabalho no processo de construção do Sistema Único de Saúde no Brasil. Acta Paul.enferm. 2004;17(3):255-61. 
20. Zanchetta MS, Leite LC, Perreault M, Lefebvre H. Educação, crescimento e fortalecimento profissional do agente comunitário de saúde - estudo etnográfico. Online braz. j. nurs. (Online). 2005;4(3).

21. Ferraz L, Aerts DRGC. O cotidiano de trabalho do agente comunitário de saúde no PSF em Porto Alegre. Cienc. Saúde Coletiva 2005;10(2):347-55.

22. Oliveira RG, Nachif MCA, Matheus, MLF. O trabalho do agente comunitário de saúde na percepção da comunidade de Anastácio, Estado do Mato Grosso do Sul. Acta Sci., Health Sci 2003;25(1):95-101.

23. Almeida EZ. As concepções do agente comunitário de saúde sobre promoção da saúde [dissertação]. São Paulo: Escola de Enfermagem, Universidade de São Paulo; 2008.

24. Peres CRFB. O trabalho do agente comunitário de saúde no município de Marília - SP [dissertação]. Botucatu: Faculdade de Medicina, Universidade Estadual Paulista; 2006.

25. Santos LPGS. A atuação do agente comunitário de saúde em São Bernardo do Campo: possibilidades e limites para a promoção da saúde [dissertação]. São Paulo: Escola de Enfermagem, Universidade de São Paulo; 2005.

26. Heidmann ITSB, Almeida MCP, Boebs AE, Wosny AM, Monticeli M. Promoção à saúde: uma trajetória histórica de suas concepções. Texto \& contexto enferm. 2006; 15(2): 352-58.

27. Carvalho SR. Os múltiplos sentidos da categoria "empowerment" no projeto de promoção à saúde. Cad Saúde Pública. 2004; 20(4):1088-95.

28. Buss PM. Promoção da saúde e qualidade de vida. Ciência \& Saúde Coletiva. 2000;5(1):163-77.

29. Freitas CM. Promoção da saúde: conceitos, reflexões, tendências. Rio de Janeiro: Fiocruz; 2003. A vigilância da saúde para a promoção da saúde; p.141-59.

30. Lopes AL. Processo de educação em saúde na cessação do tabagismo: revisão sistemática e metassíntese [dissertação]. São Paulo: Escola de Enfermagem, Universidade de São Paulo; 2008.

31. Buss PM. Promoção da saúde: conceitos, reflexões, tendências. Rio de Janeiro: Fiocruz; 2003. Uma introdução ao conceito de promoção da saúde; p.15-38. 
32. Chiesa AM. A promoção da saúde como eixo estruturante do tratamento de enfermagem no Programa de Saúde da Família. Nursing. 2003; 64(6): 40-46.

33. Nutbeam D, Haris E. Theory in a nutshell: a practical guide to health promotion theories. 2 nd ed. [S.I.]: McGraw-Hill Austrália; 2005.

34. Neto OC. Pesquisa social: teoria, método e criatividade. Rio de Janeiro: Vozes; 1999. O trabalho de campo como descoberta e criação; p.51-66.

35. Minayo MCS. O desafio do conhecimento: pesquisa qualitativa em saúde. São Paulo: Hucitec; 2004. Introdução à metodologia em pesquisa social; p.19-88.

36. Brasil. Instituto Brasileiro de Geografia e Estatística. [base de dados na internet]. Brasília; 2000-08 [citado 2008 dez 12]. Disponível em http: www.ibge.gov.br/cidadesat/topwindow.htm?1

37. São Paulo. Fundação sistema estadual de análise de dados. [base de dados na Internet]. São Paulo; 2008. [citado 2008 dez dia 12]. Disponível em http: www.sead.gov.br/produtos/perfil/perfil.php.

38. Secretaria municipal de Marília. Plano diretor 2009.

39. Vasconcellos NPC, Costa-Val R. Avaliação da qualidade de vida dos agentes comunitários de saúde de Lagoa Santa-MG. Rev. APS. 2008;11(1):17-28.

40. Bezerra AFB, Espírito Santo ACG, Batista Filho M. Concepções e práticas do agente comunitário na atenção à saúde do idoso. Rev. Saúde pública. 2005;39(5):809-15.

41. São Paulo. Decreto municipal n ${ }^{0} 28625$, de 31 de março de 90. Dispõe sobre a criação do centro de formação dos trabalhadores de saúde (CEFOR). [legislação na internet]. São Paulo; 1990 [citado 2010 jan.30]. Disponível em http://portal.prefeitura.sp.gov.br/secretarias/saude/cefor/0001/portal/secretaria s/saude/legislacao/0136. (item 8.10.6

42. Bornstein VJ, Stotz EN. Concepções que integram a formação e o processo de trabalho dos agentes comunitários de saúde: uma revisão de literatura. Ciênc. saúde coletiva. 2008; 13(1):259-68.

43. Sakata KN. A inserção do agente comunitário de saúde na equipe de saúde da família. [Dissertação]. Ribeirão Preto: Escola de Enfermagem de Ribeirão Preto, Universidade de São Paulo; 2009. 
44. Silveira MR, Sena RR. Diversidades de práticas e saberes: o caso do agente comunitário de saúde no Programa de Saúde da Família de Nova Contagem Minas Gerais. REME rev. min. enferm. 2005;9(1):59-64.

45. Jesus MCP, Santos SM, Amaral AMM, Amaral AMN, Costa DMN, Aguilar KSM. O discurso do enfermeiro sobre a prática educativa no Programa Saúde da Família em Juiz de Fora, Minas Gerais, Brasil. Rev. APS. 2008;11(1):5461 .

46. Silva MMF. Promoção da saúde: percepções dos ACS a partir de sua formação e da sua prática. [Dissertação]. São Paulo: Faculdade de Saúde Pública, Universidade de São Paulo; 2009.

47. Bedin N. O agente comunitário de saúde e o empoderamento: o caso da cordenadoria de saúde da Lapa. [Tese]. São Paulo: Faculdade de Saúde Pública, Universidade de São Paulo; 2006.

48. Nunes MO, Trad LB, Almeida BA, Homem CR, Melo MSIC. O agente comunitário de saúde: construção da identidade desse personagem híbrido e polifônico. Cad. Saúde pública. 2002;18(6):1639-46).

49. Nascimento EPL, Correa CRS. O agente comunitário de saúde: formação, inserção e práticas. Cad. Saúde pública. 2008; 24(6): p. 1304-13.

50. Hildebrand SM, Shimizu HE. Percepção do agente comunitário sobre o Programa Família Saudável. Rer Bras Enferm. 2008;61(3):319-24.

51. Landau SI, editor. Cambridge dictionary of American English. Cambridge University Press: 2000. p. 279. 
ANEXO 


\section{ANEXO I}

Nome:

Telefone para Contato e e-mail:

ANEXO I - Questionário Para Caracterização do Perfil do ACS

QUESTIONÁRIO PARA CARACTERIZAÇÃO DO PERFIL DO ACS

Qual é o seu sexo?

1. ( ) Feminino

2. ( ) Masculino

Qual é a sua idade?

Qual a sua raça/cor?

1. ( ) Branca

2. ( ) Preta

3. ( ) Parda

4. ( ) Amarela

5. ( ) Indígena

Qual a sua região de nascimento?

1. ( ) Região Sul (Rio Grande do Sul, Santa Catarina,Paraná)

2. ( ) Região Sudeste (São Paulo, Minas Gerais, Rio de Janeiro, Espírito Santo)

3. ( ) Região Centro-Oeste (Mato Grosso , Mato Grosso do Sul, Goiás, Distrito Federal)

4. ( ) Região Norte (Acre, Amazonas, Roraima, Rondônia, Pará, Amapá, Tocantins)

5. ( ) Região Nordeste (Maranhão, Piauí, Rio Grande do Norte, Ceará, Paraíba, Pernambuco Alagoas Sergipe, Bahia)

Qual o seu local de nascimento?

1. ( ) Zona Rural

2. ( ) Zona Urbana

Qual é o seu estado civil?

1. ( ) Solteiro(a)

2. ( ) Unido(a)

3. ( ) Separado(a)

4. ( ) Viúvo(a)

Qual a última série escolar que você concluiu com aprovação?

Fez algum curso profissionalizante?

1. ( ) Sim

0. ( ) Não

Caso a resposta anterior seja afirmativa, escreva o nome do curso realizado:

Quantos filhos vivos você possui?

Qual é a sua renda familiar? (total bruto) $R \$$

Quantas pessoas vivem com esta renda, incluindo você?

Você mora em casa:

1. ( ) Própria

2. ( ) Alugada

3. ( ) Cedida

4. ( ) Outros

Há quanto tempo é morador(a) do bairro onde reside?

Trabalha no bairro em que mora?

1. ( ) Sim

0. ( ) Não

Qual era sua ocupação antes de ser Agente Comunitário de Saúde (ACS)?

Possuiu carteira assinada antes de ser ACS?

1. ( ) Sim 
0. ( ) Não

Realiza alguma outra atividade remunerada além a de ACS?

1. ( ) Sim

0. ( ) Não

O que primeiramente o(a) motivou a ser ACS?

1. ( ) Gostar da área de saúde

2. ( Já conhecia o trabalho do ACS e quis trabalhar nesta área

3. ( ) Gostar de trabalhar com pessoas

4. ( ) Colaborar para melhorar a saúde da comunidade onde vive

5. ( ) Visualizou uma oportunidade de emprego, mesmo não sabendo muito bem o que iria fazer.

6. ( ) Outros. Quais?

Você gosta de trabalhar como ACS?

1. ( ) Sim

0. ( ) Não

Há quanto tempo trabalha no PACS?

Participa ou já participou de alguma atividade na comunidade? (Pode assinalar mais de 01 resposta)

1. ( ) Associação de bairro/moradores

2. ( ) Associação de pais e mestres

3. ( ) Conselho tutelar

4. ( ) Igreja/ comunidade religiosa

5. ( ) Outros. Qual? 
FORMULÁRIO DE ATIVIDADES DO AGENTE COMUNITÁRIO DE SAÚDE

Marque com um "X" a alternativa escolhida

\begin{tabular}{|c|c|c|c|c|c|c|c|}
\hline & & & Freqüênci & com que $r$ & & & \\
\hline & Atividade & & $\begin{array}{l}\text { Todos os } \\
\text { dias }\end{array}$ & $\begin{array}{l}\text { Todas as } \\
\text { semanas }\end{array}$ & $\begin{array}{l}\text { Todos os } \\
\text { meses }\end{array}$ & Raramente & Nunca \\
\hline & $\begin{array}{l}\text { Participa das reuniões } \\
\text { em equipe }\end{array}$ & A1 & & & & & \\
\hline & $\begin{array}{l}\text { Expõe suas opiniões nas } \\
\text { reuniões em equipe }\end{array}$ & A2 & & & & & \\
\hline & $\begin{array}{l}\text { Empenha-se para } \\
\text { executar as ações } \\
\text { propostas pela equipe }\end{array}$ & A3 & & & & & \\
\hline & $\begin{array}{l}\text { Orienta a comunidade } \\
\text { sobre o funcionamento } \\
\text { da UBS, atividades e } \\
\text { campanhas }\end{array}$ & A4 & & & & & \\
\hline $\begin{array}{l}\text { Integração } \\
\text { da equipe } \\
\text { com a }\end{array}$ & $\begin{array}{l}\text { Orienta a comunidade } \\
\text { quanto às ações } \\
\text { desenvolvidas nos } \\
\text { diversos serviços de } \\
\text { saúde }\end{array}$ & A5 & & & & & \\
\hline $\begin{array}{l}\text { local } \\
\text { (A) }\end{array}$ & $\begin{array}{l}\text { Traz as necessidades da } \\
\text { comunidade, que julga } \\
\text { pertinente, para serem } \\
\text { discutidas junto à equipe } \\
\text { de saúde }\end{array}$ & A6 & & & & & \\
\hline & $\begin{array}{l}\text { Faz das visitas } \\
\text { domiciliares a base para } \\
\text { o desenvolvimento das } \\
\text { suas ações como ACS }\end{array}$ & A7 & & & & & \\
\hline & $\begin{array}{l}\text { Preenche a ficha A } \\
\text { (cadastramento) para } \\
\text { todas as famílias } \\
\text { visitadas }\end{array}$ & A8 & & & & & \\
\hline & $\begin{array}{l}\text { Preenche a ficha B } \\
\text { (acompanhamento) para } \\
\text { todos os indivíduos dos } \\
\text { "grupos de risco" }\end{array}$ & A9 & & & & & \\
\hline & Preenche a ficha $\mathrm{C}$ & A10 & & & & & \\
\hline & $\begin{array}{l}\text { Estimula a população a } \\
\text { participar de conselhos } \\
\text { locais de saúde e/ou } \\
\text { conferências municipais } \\
\text { de saúde }\end{array}$ & B1 & & & & & \\
\hline & $\begin{array}{l}\text { Incentiva a população a } \\
\text { participar de atividades } \\
\text { de sua própria } \\
\text { comunidade }\end{array}$ & B2 & & & & & \\
\hline
\end{tabular}




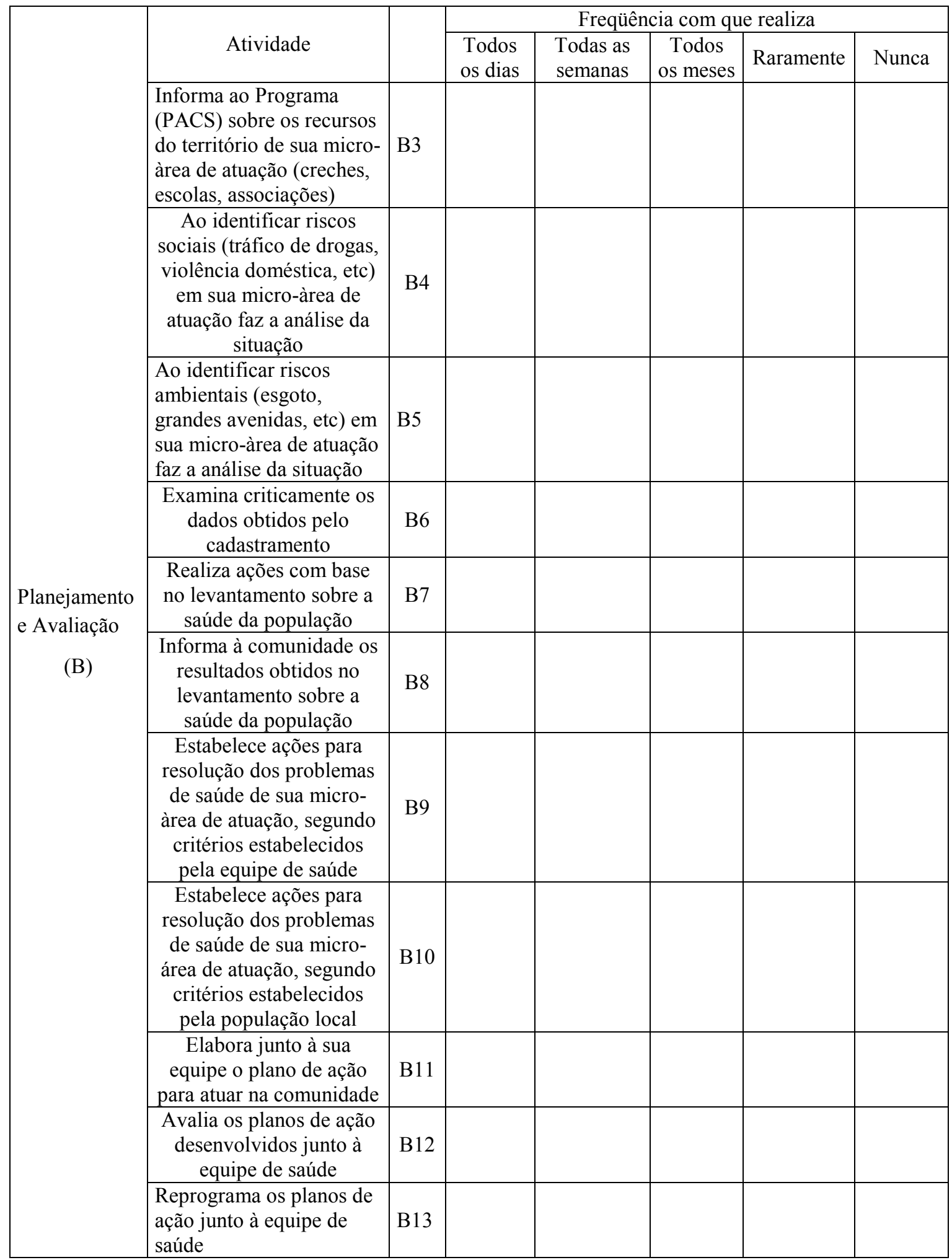




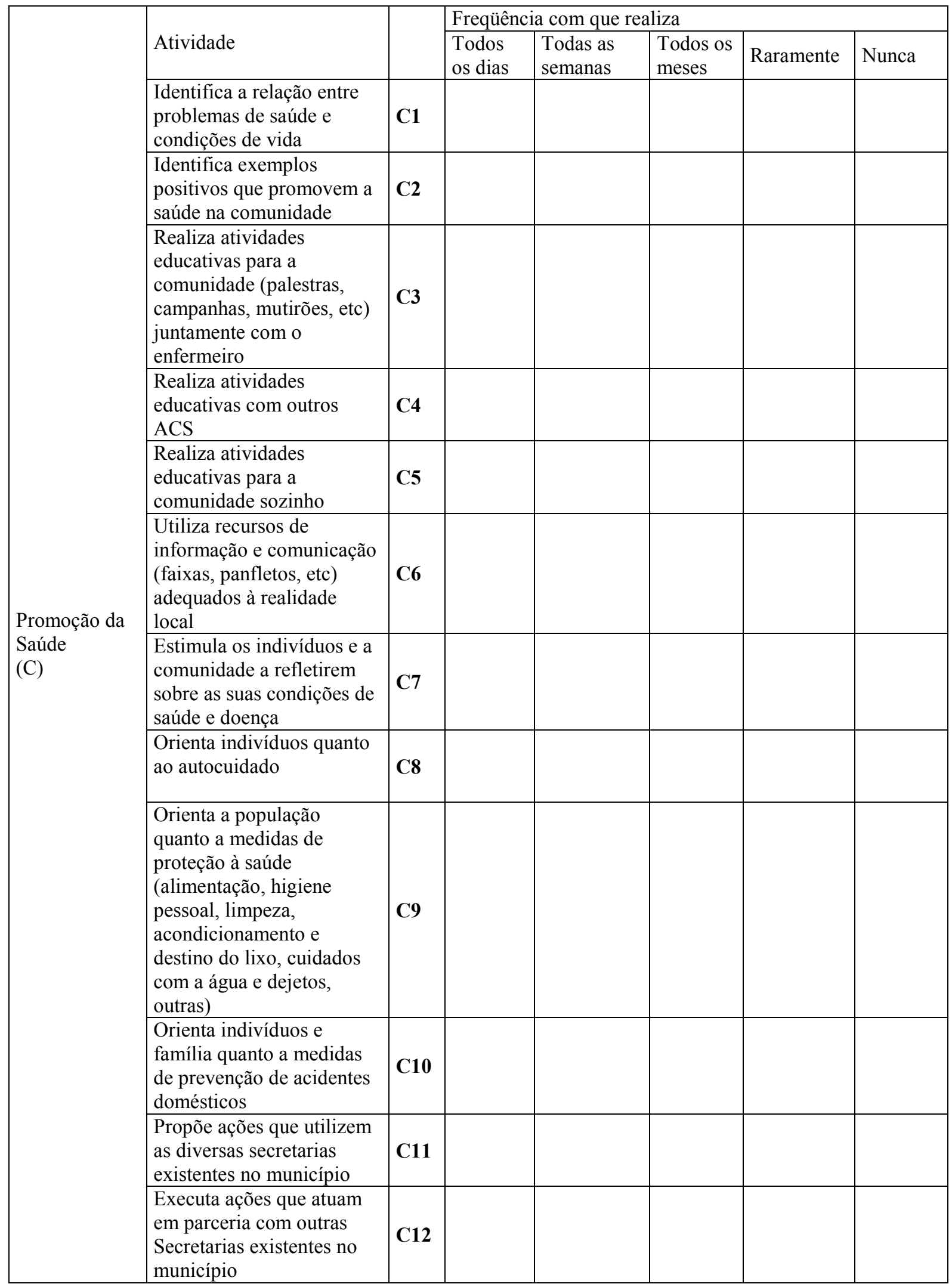


Promoção da Saúde

(C)

\begin{tabular}{|c|c|c|c|c|c|c|}
\hline \multirow[b]{2}{*}{ Atividade } & & \multicolumn{5}{|c|}{ Freqüência com que realiza } \\
\hline & & \begin{tabular}{|l|} 
Todos \\
os dias
\end{tabular} & $\begin{array}{l}\text { Todas as } \\
\text { semanas }\end{array}$ & \begin{tabular}{|l|} 
Todos \\
os meses \\
\end{tabular} & Raramente & Nunca \\
\hline $\begin{array}{l}\text { Estabelece parcerias com } \\
\text { creches, asilos, escolas, } \\
\text { comerciantes, grupos } \\
\text { socias e outros }\end{array}$ & C13 & & & & & \\
\hline $\begin{array}{l}\text { Orienta a família e/ou } \\
\text { portador de necessidades } \\
\text { especiais quanto às } \\
\text { medidas facilitadoras } \\
\text { para a sua máxima } \\
\text { inclusão social }\end{array}$ & C14 & & & & & \\
\hline $\begin{array}{l}\text { Apóia ações sociais de } \\
\text { alfabetização de crianças, } \\
\text { adolescentes, jovens e } \\
\text { adultos }\end{array}$ & C15 & & & & & \\
\hline $\begin{array}{l}\text { Participa de reuniões do } \\
\text { conselho local de saúde } \\
\text { ou de outros conselhos } \\
\text { locais }\end{array}$ & C16 & & & & & \\
\hline
\end{tabular}

Prevenção e monitoramento de risco ambiental e sanitário

(D)

\begin{tabular}{|c|c|c|c|c|c|c|}
\hline \multirow[b]{2}{*}{ Atividade } & & \multicolumn{5}{|c|}{ Freqüência com que realiza } \\
\hline & & $\begin{array}{l}\text { Todos } \\
\text { os dias }\end{array}$ & $\begin{array}{l}\text { Todas as } \\
\text { semanas }\end{array}$ & $\begin{array}{l}\text { Todos os } \\
\text { meses }\end{array}$ & Raramente & Nunca \\
\hline $\begin{array}{l}\text { Identifica as } \\
\text { condiçóes ambientais } \\
\text { e sanitárias que } \\
\text { provoquem riscos } \\
\text { para a saúde da } \\
\text { comunidade }\end{array}$ & D1 & & & & & \\
\hline $\begin{array}{l}\text { Informa à equipe de } \\
\text { saúde sobre a } \\
\text { ocorrência de } \\
\text { situações de risco, na } \\
\text { micro-área de atuação }\end{array}$ & D2 & & & & & \\
\hline $\begin{array}{l}\text { Informa à população } \\
\text { sobre a ocorrência de } \\
\text { situações de risco, na } \\
\text { micro-área de atuação }\end{array}$ & D3 & & & & & \\
\hline $\begin{array}{l}\text { Orienta indivíduos e } \\
\text { grupos quanto a } \\
\text { medidas de redução } \\
\text { ou prevenção de } \\
\text { riscos ambientais e } \\
\text { sanitários em saúde }\end{array}$ & D4 & & & & & \\
\hline $\begin{array}{l}\text { Orienta moradores e } \\
\text { famílias quanto aos } \\
\text { cuidados relacionados } \\
\text { ao ambiente } \\
\text { hospitalar }\end{array}$ & D5 & & & & & \\
\hline $\begin{array}{l}\text { Identifica indivíduos } \\
\text { ou grupos que } \\
\text { demandam cuidados } \\
\text { especiais de saúde }\end{array}$ & E1 & & & & & \\
\hline
\end{tabular}




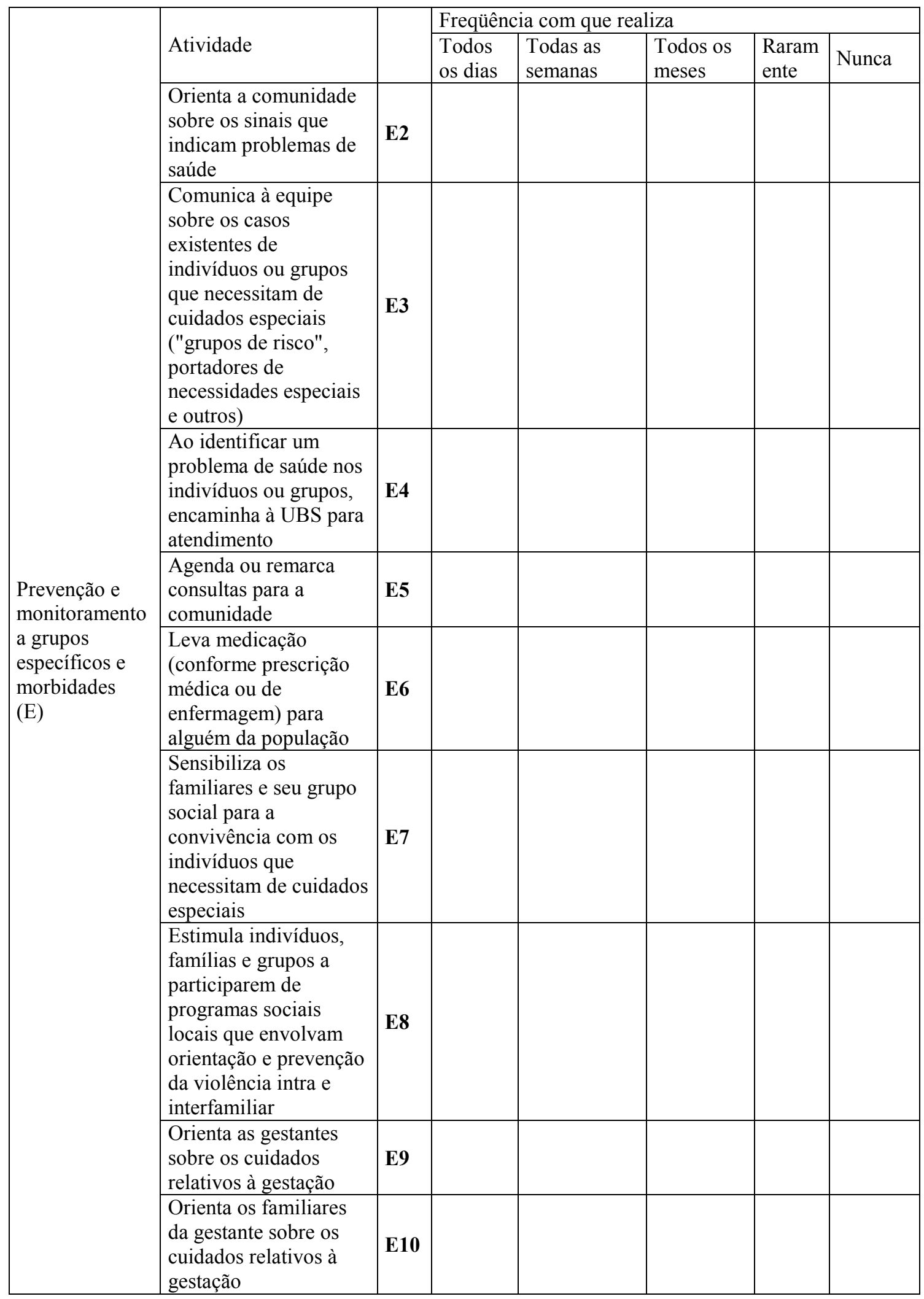




\begin{tabular}{|c|c|c|c|c|c|c|c|}
\hline & & & Freqüêr & ia com qu & ealiza & & \\
\hline & Atividade & & \begin{tabular}{|l|} 
Todos \\
os dias \\
\end{tabular} & $\begin{array}{l}\text { Todas as } \\
\text { semanas }\end{array}$ & \begin{tabular}{|l|} 
Todos os \\
meses
\end{tabular} & Raramente & Nunca \\
\hline & $\begin{array}{l}\text { Orienta as gestantes } \\
\text { sobre os cuidados } \\
\text { relativos ao parto } \\
\end{array}$ & E11 & & & & & \\
\hline & $\begin{array}{l}\text { Orienta os familiares } \\
\text { da gestante sobre os } \\
\text { cuidados relativos ao } \\
\text { parto }\end{array}$ & E12 & & & & & \\
\hline & $\begin{array}{l}\text { Orienta as gestantes } \\
\text { sobre os cuidados } \\
\text { relativos ao puerpério }\end{array}$ & E13 & & & & & \\
\hline & $\begin{array}{l}\text { Orienta os familiares } \\
\text { da gestante sobre os } \\
\text { cuidados relativos ao } \\
\text { puerpério }\end{array}$ & E14 & & & & & \\
\hline & $\begin{array}{l}\text { Orienta gestantes, } \\
\text { puérperas e grupo } \\
\text { familiar quanto ao } \\
\text { aleitamento materno }\end{array}$ & E15 & & & & & \\
\hline $\begin{array}{l}\text { Prevenção e } \\
\text { monitoramento } \\
\text { a grupos } \\
\text { específicos e }\end{array}$ & $\begin{array}{l}\text { Orienta gestantes, } \\
\text { puérperas e grupo } \\
\text { familiar quanto aos } \\
\text { cuidados com o recém- } \\
\text { nascido }\end{array}$ & E16 & & & & & \\
\hline $\begin{array}{l}\text { morbidades } \\
\text { (E) }\end{array}$ & $\begin{array}{l}\text { Solicita o passaporte } \\
\text { materno-infantil nas } \\
\text { visitas domiciliares }\end{array}$ & E17 & & & & & \\
\hline & $\begin{array}{l}\text { Orienta indivíduos } \\
\text { quanto à saúde sexual e } \\
\text { reprodutiva }\end{array}$ & E18 & & & & & \\
\hline & $\begin{array}{l}\text { Acompanha o } \\
\text { crescimento infantil }\end{array}$ & E19 & & & & & \\
\hline & $\begin{array}{l}\text { Acompanha o } \\
\text { desenvolvimento } \\
\text { infantil }\end{array}$ & E20 & & & & & \\
\hline & $\begin{array}{l}\text { Solicita o cartão de } \\
\text { vacina das crianças nas } \\
\text { visitas domiciliares }\end{array}$ & E21 & & & & & \\
\hline & $\begin{array}{l}\text { Orienta indivíduos e } \\
\text { famílias sobre as } \\
\text { medidas de prevenção } \\
\text { e controle das doenças } \\
\text { não transmissíveis } \\
\end{array}$ & E22 & & & & & \\
\hline & $\begin{array}{l}\text { Orienta indivíduos e } \\
\text { famílias sobre as } \\
\text { medidas de prevenção } \\
\text { e controle das doenças } \\
\text { transmissíveis }\end{array}$ & E23 & & & & & \\
\hline
\end{tabular}




\section{ANEXO II}

\section{Termo De Consentimento Livre e Esclarecido}

Título da Pesquisa: As Potencialidades do Agente Comunitário de Saúde na Efetivação da Promoção da Saúde: uma análise do seu trabalho no município de Marília

Pesquisadora responsável: Adriana Avanzi Marques Pinto

Orientador: Lislaine Aparecida Fracolli

1. O estudo a que se refere este consentimento livre e esclarecido tem caráter investigativo e é referente a uma pesquisa de mestrado da Escola de Enfermagem da Universidade de São Paulo (EEUSP)

2. O estudo tem por objetivo descrever e problematizar as ações de promoção do ACS com base nas competências do Ministério da Saúde e analisar as ações relacionadas à competência da Promoção da Saúde, buscando identificar as concepções que dão suporte a essas ações.

3. Como procedimentos metodológicos os dados serão coletados a partir da aplicação de um questionário para a caracterização dos ACS e um formulário que buscará identificar as ações que este profissional realiza, bem como a freqüência com a qual executa essas ações. A seguir essas informações serão qualificadas através da percepção dos próprios ACS.

4. Os ACS terão liberdade para manifestar-se, poderão fazer qualquer questionamento acerca do estudo e de sua participação, devendo ser esclarecido sobre suas dúvidas em qualquer momento da pesquisa. Garante-se o sigilo acerca da identidade do informante e sua participação é voluntária, ou seja, seu nome não será divulgado em nenhum momento do estudo, tendo o sujeito da pesquisa toda a liberdade de recusar-se a participar do estudo, sem que isso represente qualquer prejuízo, desconforto ou risco à sua pessoa ou ao desempenho de seu trabalho.

5. Todas as informações obtidas através do questionário e formulário deverão ser mantidas sob sigilo e em lugar seguro.

6. Os resultados deverão ser descritos e analisados em um relatório formal que, ao seu término será apresentado publicamente, aos ACS as quais se refere o estudo e em instancias publicas como congressos, periódicos e afins.

7. Maiores esclarecimentos poderão ser obtidos com a pesquisadora responsável Adriana Avanzi Marques Pinto - fone: (14) 3432-2682 ou (14) 8114-0332 e com a orientadora da pesquisa Lislaine Aparecida Fracolli - fone: (11) 3066 - 7652 ou com o Comitê de Ética em Pesquisa da Escola de Enfermagem da USP São Paulo - (11) 3061-7548

Declaro que, após convenientemente esclarecido pela pesquisadora responsável e de ter compreendido com clareza suas finalidades, procedimentos metodológicos e o destino final das informações recolhidas, consinto em participar livremente do estudo a que se refere este consentimento informado.

Marília,.... de. de 2009.

Assinatura do ACS 